University of Louisville

ThinkIR: The University of Louisville's Institutional Repository

Electronic Theses and Dissertations

$5-2017$

\title{
Oil, space, and national imaginaries : discursive productions by standard oil New Jersey post WWII.
}

Michael Poindexter

University of Louisville

Follow this and additional works at: https://ir.library.louisville.edu/etd

Part of the Geography Commons

\section{Recommended Citation}

Poindexter, Michael, "Oil, space, and national imaginaries : discursive productions by standard oil New Jersey post WWII." (2017). Electronic Theses and Dissertations. Paper 2653.

https://doi.org/10.18297/etd/2653

This Master's Thesis is brought to you for free and open access by ThinkIR: The University of Louisville's Institutional Repository. It has been accepted for inclusion in Electronic Theses and Dissertations by an authorized administrator of ThinkIR: The University of Louisville's Institutional Repository. This title appears here courtesy of the author, who has retained all other copyrights. For more information, please contact thinkir@louisville.edu. 


\title{
OIL, SPACE, AND NATIONAL IMAGINARIES: DISCURSIVE PRODUCTIONS BY
} STANDARD OIL NEW JERSEY POST WWII

\author{
E I \\ Michael Poindexter \\ B.A., University of Louisville, 2010 \\ A Thesis Submitted to the Faculty of the \\ College of Arts and Sciences of the University of Louisville \\ in Partial Fulfillment of the Requirements \\ for the Degree of \\ Master of Science in Applied Geography \\ Department of Geography and Geosciences \\ University of Louisville \\ Louisville, Kentucky
}

May 2000 



\title{
OIL, SPACE, AND NATIONAL IMAGINARIES: DISCURSIVE PRODUCTIONS BY
} STANDARD OIL NEW JERSEY POST WWII

\author{
By \\ Michael Poindexter \\ B.A., University of Louisville, 2010 \\ A Thesis Approved on \\ April 26, 2017 \\ by the following Thesis Committee:
}

Dr. Margath Walker

Dr. Carol Hanchette

Dr. Lauren Heberle 


\section{ACKNOWLEDGMENTS}

First I would like to thank my advisor, Dr. Margath Walker, for her longstanding support, advice and insight throughout this project. Her commitment to academic discipline is a quality I greatly admire and hope to emulate in this thesis. This project would have not been possible without the support and advice of my committee members. I thank Dr. Carol Hanchette for her encouragement throughout my time in the program. I thanks Dr. Heberle for her incredible example of how to be an academic but also engage in local community issue. I am grateful to the University of Louisville Geography department. My time spent here, engaging with the discipline, has been the most influential and significant in my life. I would also like to thank the other graduate students the program for their camaraderie, specifically Paula Gomez, who has encouraged me incessantly. And I would like to thank the Special Collections at Ekstrom Library for their assistance, insight and ability to make archival research pleasant and not so tenuous. Photographs used in the thesis are with special permission of the Special Collections Archive.

I could not have completed this thesis without the support of my family and friendsmy mom, my dad, my sister and my grandparents. Rebecca Katz has been a source of strength and inspiration and I am so grateful. 


\begin{abstract}
OIL, SPACE, AND NATIONAL IMAGINARIES: DISCURSIVE PRODUCTIONS BY STANDARD OIL NEW JERSEY POST WWII

Michael Poindexter

\$ SU⿴囗, 2017
\end{abstract}

In a moment of self-representation, Standard Oil New Jersey commissioned a large photo 'documentary' project of nearly 80,000 images taken between the years 1943 to 1950 . Produced for publication and exhibition, images captured "how oil seeped into every joint" of America, and displayed a specific landscape for post WWII economies. While a stable and centralized industry was ever more tied to the state's idea of national security, Standard Oil needed a public relations project to address social concerns of big oil. This singular perspective on oil space is problematic. Community histories and social relations are seen through Standard Oil's own restrictive frame. Representation gives the appearance that Standard Oil is asserting itself in a neutral photo documentary journalism project in post WWII America. However it is the image that deterministically maps out and proliferates economic life under capital. It is the image that flattens out the complexity of spatial political relations. A discursive read illuminates the productive work of the image and asks questions commonly used by historical materialists: How is the relation to nature being articulated? How is daily life being reproduced? How are social relations being normalized? And what kind of symbolism is being projected? This thesis proposes to show how Standard 
Oil produces and reproduces national imaginaries and/or identities in the following spheres: 1) visualizations of oil towns, 2) politics of conservation, and 3) discourses on foreign production in Venezuela. This paper focuses on the spatial tactics visual representation uses to acclimate post WWII Americans to the dynamic structures of capitalism. 


\section{TABLE OF CONTENTS}

PAGE

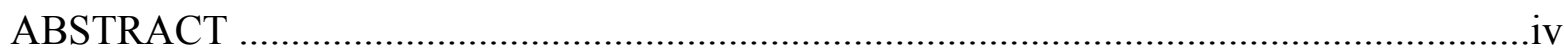

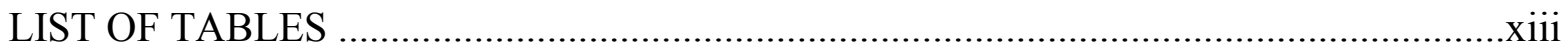

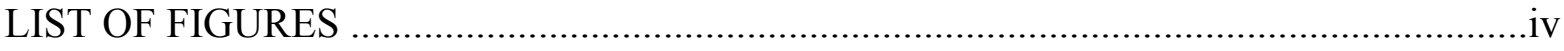

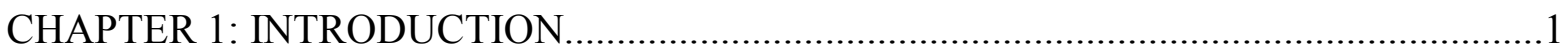

The SONJ Photograph Collection...............................................4

CHAPTER 2: THEORETICAL FRAMEWORK AND METHODOLOGY: DISCOURSE

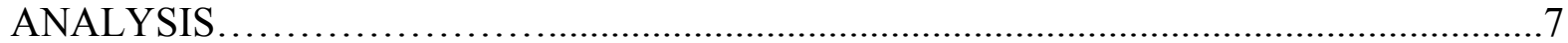

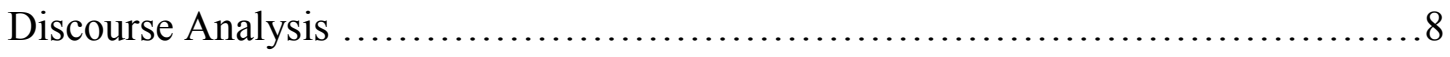

The Site of Production- An Approach to the SONJ Archive .........................11

Oil, Representation and Discourse in the Literature .............................14

Discourses of Everyday Oil Practices ..................................... 18

Production of Space: Discourse and Geography ............................20

CHAPTER 3: THE SONJ PUBLIC RELATIONS DEPARTMENT HISTORY AND THE 'HUMAN' ASPECT OF OIL ................................................................................ 22

A Scandal and the SONJ Public Relations Department ..........................26

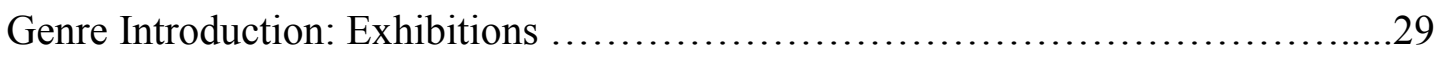

CHAPTER IV: PRODUCTION OF OIL TOWNS, OIL COUNTRY AND THE SCOPIC REGIME OF AMERICANA..................................................... 35

Oil Town U.S.A: Representations of Tomball, Texas and Cut Bank, Montana........37

Cushing, Oklahoma and the Production of an Oil Country........................48

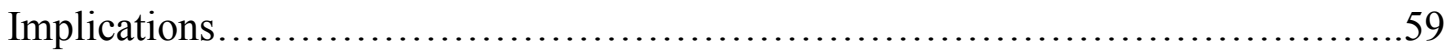

CHAPTER V: THE SONJ PHOTO MEMO AND CONTRADICTIONS IN THE POST

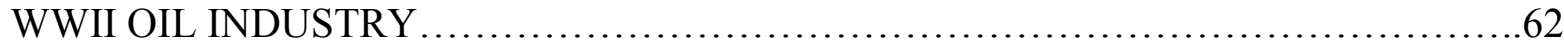

Patterns of Oil: Photo Memo Introduction.................................64

Conservation and Venezuela in the Photo Memo...............................67

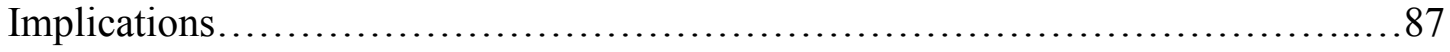




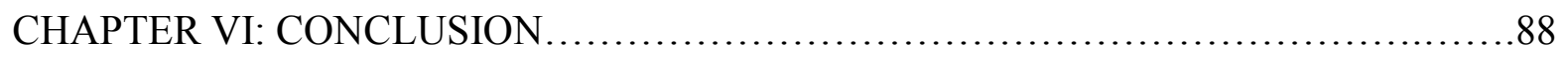

Contributions.................................................... 90

Limitations...................................................... 91

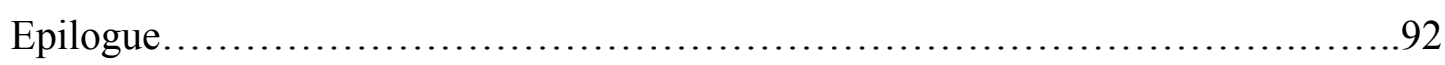

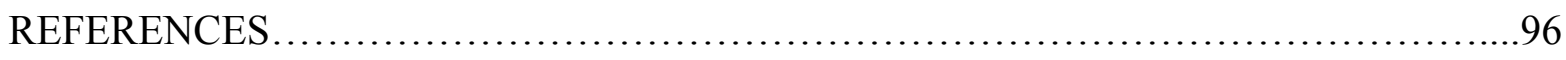

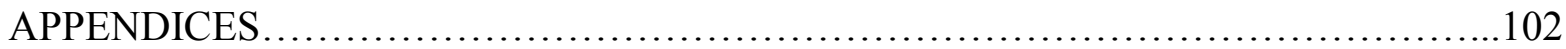

CURRICULUM VITA........................................................ 108 


\section{LIST OF TABLES}

TABLE $\quad$ PAGE

1. World Oil Consumption, 2013 ...........................................2

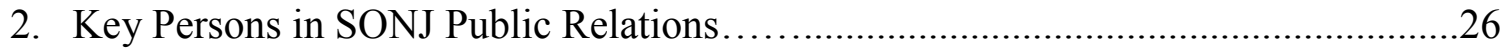

3. Earl Newsom Poll Summary for SONJ Board November 2, 1942 .................28

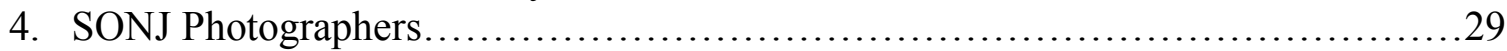

5. SONJ Photo file 'Training Program': Film Strip Captions.......................... 80

6. Latin American Affiliate Companies sent nucleus photo set......................93

7. European Affiliate Companies sent nucleus photo set.......................... 94 


\section{LIST OF IMAGES}

IMAGES

PAGE

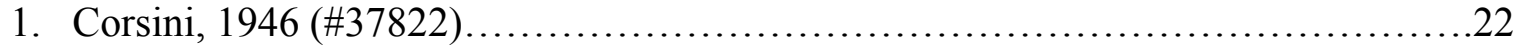

2. Coronet Magazine cover. 1946. Coronet Magazine..................................... 37

3. Oil Town U.S.A title page. 1946. Coronet Magazine..................................37

4. Oil Town U.S.A. 1946. page 13 Coronet Magazine.................................40

5. Oil Town U.S.A. 1946. page 17 Coronet Magazine...............................41

6. Oil Town U.S.A. 1946 page 19 Coronet Magazine..................................41

7. Oil Town U.S.A. 1946. page 20 Coronet Magazine...............................44

8. Oil Town U.S.A. 1946. page 27 Coronet Magazine.................................44

9. Oil Town. 1945. SONJ Photo Memo No 1. Page 13...............................46

10. Oil Town. 1945. SONJ Photo Memo No 1. Page 15...........................47

11. Cement, Oklahoma. Corsini, 1946 (\#33311).......................................50

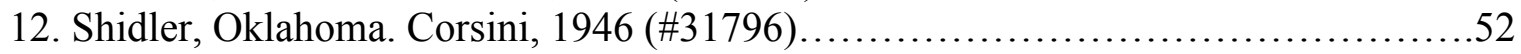

13. Oil Town 1927. 1950. Oil for the World.....................................54

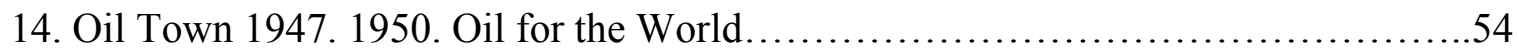

15. Oil Country. 1947. SONJ Photo Memo No 4 .....................................55

16. Carter Oil Trailer Camp. Rosskam. 1944. (\#12180)..................................58

17. Famer. 1948. SONJ Photo Memo No. 5. Page 14.................................6 60

18. Little Wheels. 1948. SONJ Photo Memo No. 5. Page 14 ...........................60

19. Patterns of Oil. 1946. SONJ Photo Memo No. 2. Pages 6-7........................65

20. Conservation. 1947. SONJ Photo Memo No 4. Pages 14-15......................69

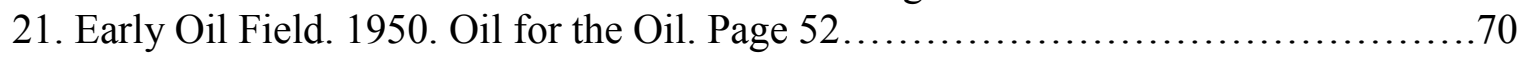

22. Modern Field Showing Well Spacing. 1950. Page 52............................ 70

23. Trip to the Jungle. 1945. SONJ Photo Memo No 1. Page $2-3 \ldots \ldots \ldots \ldots \ldots \ldots \ldots \ldots . \ldots 74$

24. Caripito, Venezuela. 1945. Photo Memo No 1. Page 4............................ 76

25. San Joaquin Worker. 1945. Photo Memo No 1. Page $11 \ldots \ldots \ldots \ldots \ldots \ldots \ldots \ldots \ldots . \ldots . \ldots . \ldots 77$

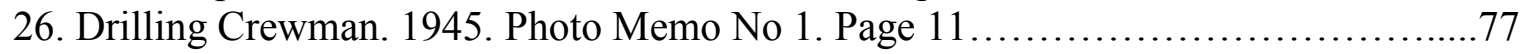

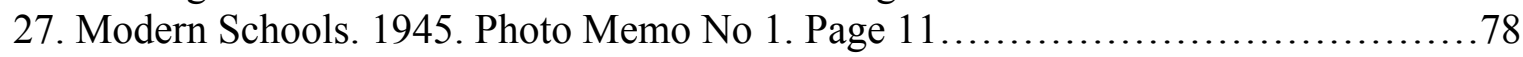

28. Lake Maracaibo. Film Strip to Encourage Photography............................ 81

29. Lake Maracaibo. Vachon. 1944. (\#1475)...................................... 83 


\section{CHAPTER I}

\section{INTRODUCTION}

Oil has been considered by scholars to be the 'lifeblood' of US capitalism (Huber 2013). Import and export comparisons, oil barrel supply counts, petro-states' GDP dependencies, monstrous industry profits, perceived and real market demands and records of the like are all quantitative accounts of the material consumption of oil and its implications. However, these material variables are deemed important with little explanation because oil is already assumed to be integral and commonplace in everyday practices. However, oil's importance in the U.S. is predicated on a culture of petroleum use defined by transportation in auto-centric spatialities and the consumption of products afforded by petroleum - heating fuel, asphalt, plastics, petrochemicals. Spatialities refers to the understanding of space in the mobilization of social relations. The need to consider a culture of oil and its discursive production is ever more important due to the dire crisis related to it: unstable geopolitical

relations (Le Billion and Cervantes 2009; Labban 2008; Watts 2008; Klare 2004; Coronil 1997), military conflict (Klare 2001), and global warming's threatening of lives and ecosystems (National Research Council 2002). The narratives of these crisis all share a common understanding that oil is crucial to the most basic functions of the US economy 
including agriculture, healthcare, transportation, consumer goods, and an endless list of direct and indirect relations with oil as the reference point. Thus, US oil consumption (Table 1), at over a fifth of global oil consumption per country, is a central concern in addressing a wide range of crisis.

\begin{tabular}{|l|l|l|l|}
\hline Rank & Country & $\begin{array}{l}\text { Consumption } \\
\text { (thousands of } \\
\text { barrels per day) }\end{array}$ & $\begin{array}{l}\text { Percent of } \\
\text { total (\%) }\end{array}$ \\
\hline 1 & United States & 18,961 & 21 \\
\hline 2 & China & 10,480 & 12 \\
\hline 3 & Japan & 4,557 & 5 \\
\hline 4 & India & 3,660 & 4 \\
\hline 5 & Russia & 3,493 & 4 \\
\hline 6 & Brazil & 3,003 & 3 \\
\hline 7 & Saudi Arabia & 2,961 & 3 \\
\hline 8 & Germany & 2,435 & 3 \\
\hline 9 & Canada & 2,374 & 3 \\
\hline 10 & Korea, South & 2,328 & 3 \\
\hline
\end{tabular}

Table 1. World Oil Consumption, 2013. (Source: Energy Information Administration, 2016)

The temptation is to perceive oil, oil practices and oil use to be an unavoidable condition of our world and so the problematics of oil are also unavoidable. For example, we have an absolute distance between home and work. Traveling between the two points requires simply accepting a degree of participation in the known problems of oil. Huber discusses this as effect of a discourse of oil addiction (2013). But a culture of oil use did not organically or naturally appear after years of U.S. consumers driving to and from work. Scholars have identified the material and political practices that elucidate the oil industry in a more politically complex and productive role than the obvious refining of an apolitical resource as an energy commodity. Recent work has further theorized the oil industry as an ontological construct in U.S. political, economic and cultural history (Bridge and Le Billon 
2013; Kashi and Watts 2010; Salas 2009; Sabin 2005; Black 2000). Multi-disciplinary scholarship has tracked the representational practices, persuasion strategies and symbolic pervasiveness of the oil industry through the appropriation, translation and redistribution of various cultural mediums (Barrett and Wordon 2012; Buell 2012; Frohardt-Lane 2012; Gisoudi and Davidson 2012; Le Menager 2012; Musiol 2012; Patchet 2012, Szeman 2012; Worden 2012, Zuck 2012). Oil, as it is imagined through texts such as film, public art, documentaries, war propaganda, and photography, produces particular discourses on both the oil industry and on capitalism. Generally, this intervention confronts oil as an unassailable fact, showing that the oil industry discourses have been successful in producing 'oil subjects', revealing some of the epistemological problems of U.S. oil consumption. These problems are expressed in social and ecological contradictions in the moments of the very crisis that we face: geopolitical conflict, sprawling development and climate change. A complex set of cultural discourses that are in themselves sometimes contradictory, allow for the continued consumption of vast amounts of oil in the U.S.

This thesis project looks at one moment of cultural production in the history of oil: the photograph collection produced by the Standard Oil New Jersey (SONJ) public relations department during the years 1943-1951. This is an account of the promotional culture of the petroleum industry that explores the intersections of traditional photography documentation and industry publicity and illuminates the vital role that cultural representation played in acclimating postwar American consumers to the dynamic structures of oil. This project is an application of discourse analysis as defined by Gillain Rose (2001) upon a single archive consisting of various text genres. This application will focus on the productive work of the image but will employ the use of supplementary texts in the archive. This is an iterative 
approach without a traditional starting research question. However, this project does make use of questions typical of a discourse analysis (Rose 2001): How is daily life being reproduced? How are social relations being normalized? And what kind of symbolism is being projected? These will in sum answer the more overarching research question: How does the SONJ photograph collection discursively reproduce a culture of petroleum use in the U.S.?

\section{The SONJ Photograph Collection}

In 1968, the whole SONJ photographic file was moved to the University of Louisville through the personal connections between project director Roy Stryker and the school. All other archival material for the SONJ exists in Texas with Exxon's archive. For that reason, it is an outlier and a unique case. The introduction of a massive photographic archive was the beginning of the special collections at the University. To this day, the SONJ collection is still known as the Special Collections' signature collection. However, the majority of requests on the file are not necessarily looking for oil related content. The archive is a great example of postwar period related requests (see Out of the Forties by Lemann -1983). Because the archive is well organized, it is easy to find location-based requests and specific content inquiries. Many of the photographers who worked on the project were already well known within the profession before they worked for SONJ or they went on to become famous after leaving. The archive is a good source for quality prints from famous American photographers. For example, the Special Collections curated a gallery of Esther Bubley's work in 2015 and used SONJ photos among others. Many users of the archive are not directly looking for information on the oil industry. Their end use for the visual will most likely not have anything to do with petroleum. However, this simple anecdote is further 
evidence of the pervasiveness and taken-for-granted nature of oil culture in America - that we can, seventy years later, view a text that was originally meant to document oil, and we no longer see the 'oil' in it. Therefore, I argue this to be a justifiable and significant site of analysis.

Chapter 2 introduces discourse analysis as both an ontology and a methodology. I define the terms using Gillian Rose's methodology for analyzing multiple genres of texts including visual images (2001). Examples from the literature on discourse analysis and oil culture is given to provide a basis how my methods are employed.

Chapter 3 reviews the historical context of the SONJ archive both in terms of transitions within SONJ's own corporate organization and changes in a broader oil industry. The photographic file was just one initiative that the newly formed public relations department undertook. Using internal correspondence, this chapter contextualizes the photo file within the larger goals of SONJ public relations.

Chapter 4 examines several moments which demonstrate the production of space in oil towns. The mechanism of photography was used to produce a particular understanding of oil extraction spaces and the meaning attached to those spaces. Using what I call the scopic regime of the Americana, SONJ paired itself with visions of American small towns to produce a discourse of oil as ordinary and uncontroversial.

Chapter 5 deals with the intertextuality of a wide spectrum of subject matter that characterizes the SONJ photographic collection. Intertextuality is the relationship between texts that produces discourse. As a result, the SONJ archive preforms as a conceptual map. The role of this mapping integrates the oil industry through an overly simplified organization. 
The engineered text of the photograph allows for the flattening and simplifying of complex and controversial issues. I contextualize two of these issues, conservation and foreign oil production. While these issues are usually not discussed together, the SONJ project forces their intersection. The texts rely on each other to cover up the contradictions inherent in the industry.

In the final chapter, I summarize the thesis and propose contributions made Geography, to Geographies of Oil, and to a broader study of energy as an ontology. In an epilogue, I show some of the broader implications of the photographic collection. The practice of photography was established and the use of the photo visual images in promotion continued at SONJ and beyond to other companies. The photos of this collection have been employed for purposes not directly related to oil.

This thesis is significant because this archive has not been examined with this specific methodology before: a discourse analysis that incorporated the analysis of visual texts. Furthermore, because every 'archival fieldwork' experience (Harris 2001) is a little different, my time spent in the archive contributes to a discussion on methodology and on the archive as a site for Geography study. Further, this thesis can serve as a reference for discursive strategies used by the oil industry during the pivotal years in the oil industry following WWII. 


\section{CHAPTER II}

\section{THEORETICAL FRAMEWORK AND METHODOLGY}

This thesis is an execution of a critical discourse analysis that employs multiple and heterogenous genres of texts produced by the Standard Oil New Jersey's public relation department. The texts are found in the SONJ photo archive in the University of Louisville Special Collections. It was not chosen as a source with a particular research question in mind. Rather, I chose this research site because I found the archive personally fascinating. Its study is justified based on the following: the material is rich in substance and well organized; the content is an authoritative reference for an important period in US history, oil history and the growth of capitalism; the topic of oil and energy and their discursive power is still relevant at present given the taken-for-granted nature of our dependence and the worsening environmental impact of burning carbon based fuels; and lastly, this photo archive has yet to receive a critical analysis of any kind. I approached the archive as an open site for questions. And many questions remain. My process was iterative as figures and documents began to emerge as important through multiple rounds of reading. Key topics captured my focus as I read relevant literature in Geography and multiple histories of oil, Standard Oil and post WWII history. And so, this is not a project of single emphases but rather a 
juxtapositioning of [oil, Standard Oil, and US post WWII] histories. Further, this is not a genesis of oil culture in the U.S. but a window to a particular period. By focusing on the photo archive as a technology of Standard Oil's public relation apparatuses, this thesis project will discuss discourses that have characterized and produced a culture of petroleum use in the US post WWII.

This chapter introduces discourse as both an ontology and methodology, particularly 'critical' or Foucauldian discourse, reviews what geographer Gillian Rose has called the 'site of production' and the 'site of distribution' and how I use these distinctions to compare texts genres within the archive and reviews examples in the literature of discourse analysis and oil. This final section serves both as an example of method and provides a theoretical background to a culture of oil-use in the US.

\section{Discourse Analysis}

One of Human Geography's goals is to study the ways in which space is socially constructed. Thus, there exists a need to study both the representations of spaces and the production of those representations. While discourse analysis is a method used by many disciplines, it is one method that geographers employ to accomplish this goal (Crang 2010; Rose 1997). Generally, discourse is understood as a narrative or commonly held belief about any topic. But in an academic sense, discourse has a more precise and productive character. Here discourse is understood as "a group of statements that structure a way a thing is thought, and the way we act on basis of that thinking" (Rose 2001; 136). 'Statements' can broadly encompass ideas, concepts, categories and many immaterial texts. The 'way we act' can refer to a wide set of social practices and norms. Discourse as an ontology assumes that 
the world is continually being produced and reproduced by discourse, structuring how we understand the world and what is done in it. And while discourse analysis can have any number of foci, a critical discourse analysis is concerned with the relationship between power and knowledge. It recognizes that the ability to produce discourse is a relation of power. A specific 'critical' ontological understanding of discourse then is key in the study of social difference, power relations and the cultural other (Rose, 2001). French sociologist Michel Foucault's theories are key in the delineation of critical discourse analysis as a method. Foucault (1972) studied the relationship between power and the production of knowledge by examining particular periods in Western history where the institutions and the social practices attached to those institutions displayed clear changes. He studied the history of modern science, of modern medical practice, the emergence of the modern criminal justice system, and societal notions of sexuality. He revealed that what gave institutions power was discourse and discourses' ability to produce subjects who would be disciplined in their interaction with those institutions, i.e. patients (and medical workers) vis-à-vis the medical industry or citizens and law enforcement vis-à-vis the state's criminal justice system. Subjects then are defined by and disciplined by discourse (Foucault 1977). Through this, Foucault showed power to be not just the ability to produce discourse but rather discourse was power in and onto itself (1977). This is not a top down view of power but rather an understanding that the disciplining power of discourse is everywhere because discourse is everywhere. Since Foucault's histories, analytical methods have been delineated from his execution and topical concerns have been established from his framework. Critical discourse analysis has specific concerns: the social construction of difference, social institutions/technologies and their practices, and relationships of power (Rose 2001). And 
while researchers who use critical discourse analysis as a method all study these topics as they are articulated through discourse, there are differing foci of application that end up producing differing types of studies.

Rose makes a distinction within the method, largely based upon what type of source material the study ends up analyzing and how it is treated (2001). A method she calls 'Discourse I' might look at written and visual texts, the production and rhetorical organization of those texts and this is followed by analysis. This is used to discuss the discursive power to produce claims of truth and the production of social difference (2001;163). While 'Discourse II' also looks at written and visual texts, it is concerned with the production and reiteration of particular institutions and their practices, and then in turn the production of particular human subjects $(2001 ; 165)$. This distinction is not always clearly demarcated within the literature. In fact, it is rare that authors who study the discursive power of texts ever give a guided methodological account. Critical discourse analysis is usually known only through the content of the analysis and the style of the author. That said, for my purposes Rose's distinction is helpful. Because my primary source material is produced not only by one institution but by one company, I have used 'Discourse II'. This method is primarily concerned with what Rose has called the site of production and when available, the site of distribution. Analyzing the production of the photographic archive at the site in which it was produced reveals the rules, codes and norms of Standard Oil at the time. This reveals discourse on both oil use in the US but also corporate culture. This site of production can then be a reference for the production of a petroleum use culture and petroleum using subjects in the U.S. 
The Site of Production - An Approach to the SONJ Photo Archive

In this section I discuss archival research and its role in Geography, and then discuss methods that were specifically helpful for my project. I explain how a distinction between genre categorization of documents was instrumental in my analysis. This distinction allows for a discussion on how and why and for what purpose this archive was produced. I use Gillain Rose's term 'site of production' to describe this moment (2001).

Researchers who examine archives make the initial decision between 'source-oriented' research and problem-orientated research (Baker, 1997). A source-orientated project is primarily an in-depth examination of a single archive. A problem-oriented project involves coming up with a research question first and then constructing a historical record that is relevant with archival documents - sometimes multiple archives are used. My project is the former, source-oriented. This approach requires time spent in the archive reading, reflecting, and taking notes without a clearly defined destination in mind. (Bailey, Brace and Harvey 2009; Harris 2001). It is not an aimless pursuit. Lorimer describes it as a process of familiarization that constantly makes new associations that then lead to new quarries upon the old archive documents that have already been examined $(2009 ; 58)$. Harris calls this process 'archival fieldwork' (2001). Harris warns that the danger in fieldwork is to try to exhaustively read everything in the archive to completion, and then end up with a lot of notes and weak ideas on how it is all significant $(2001 ; 330)$. At times, I was swallowed up by the archive in this manner. When I was most productive, I was reviewing notes and reading contextual oil literature simultaneously. My reflection on the archive informed my reading of literature and vice versa. For example, I continuously came across documents in the archive that prioritized the spacing out of new oil wells and the visual of orderly oil derricks 
that were spaced far apart from each other. I only knew this to be important once I read literature on how this planned spacing was different than most of the history of chaotic oil extraction prior. This interpretation required an iterative back and forth reading.

Geographers who use archives take up a variety of topics: past representations of an empirical site (Harris 2001; Withers 2002); the social production of a landscape (Hanlon 2001), historical socio-spatial or socio environmental representations (Lorimer 2007; Kurtz 2001: Rose 2003, 2001, 2000; Sekula 1989 and 1986). Regardless of the topic of research and regardless of the methodology, historical interpretation requires researchers to be attuned to the unevenness of the historical record and critical of the politics of preservation (Hanlon 2001). Rose delineates research techniques for considering the political nature of the archive by focusing on the conditions under which the information is produced (2001). I review these techniques.

Multiple compositional modalities or genres are utilized in this project. These genres are heterogenous in content, style and structure. Often different genres are examined simultaneously and are compared to each other. This intertextual method relies on the juxtapositioning of texts that may originally not have been paired together in the archive. In fact this is an important aspect of discourse - the meaning of one discursive text depends not only on that text but on meaning carried by other texts (Rose 2001; 136). In my archive for example, an initial photograph caption may be compared to an edited captioned created for a specific curated gallery or publication. A proposed shooting script may be compared with the photographs that ended up being taken. The correspondence letters between photographers and the project director may be compared to the correspondence between public relation positions. This method has the potential to reveal interesting information - 
assumptions, casual common sense beliefs, background knowledge, and the mundane values, norms and habits of Standard Oil New Jersey and the larger US oil culture. However, some texts are difficult to categorize by their genre. For example, while all photographs in the archive are commissioned by Standard Oil for the expressed purpose of historical documentation, often there are dual uses and purposes that change as the text is distributed: photo as education, as art, as promotion, as context and as evidence. The uneasy tension in categorization is a challenge for my archives however, it is also an object of analysis in my thesis.

A further challenge will be the ordering of texts. Not all information is relevant, not all juxtapositions are helpful and not all moments of tension are interesting. Critical discourse analysis prioritizes the creation of categories, concepts, theories, and relations that reinforce (or challenge) political institutions and power relations. And while I could choose to discuss any number of the thousands of pieces of text in the archive, my priority should reflect the priority of discourse analysis as a method. This choice is not solely left up to my interpretation of the text. The significance and productive work of the discourses is known through context: where were these images seen and by whom?; how were they distributed? The Standard Oil Public Relations department chose to highlight certain photographs over others in an annual advertisement of the archive called "The Photo Memo." They chose to curate exhibits and 'photo stories' around chosen themes. Additional secondary materials illuminate the historical atmosphere of the oil industry post World War II and will define wider social constructions that are in turn being reproduced. These secondary materials include: journals and magazines where the images were published such as Standard Oil's 
own journal The Lamp, Coronet magazine, historical narratives using the photographs, and biographies on Roy Stryker (Anderson 1977) and on the photographers commissioned.

Oil, Representation, and Discourse in Literature

Geographers have identified the political processes and discursive work elucidated by the oil industry putting the industry in a more complex role than the obvious producing and marketing an energy commodity. Recent work further theorizes the oil industry as an ontological construct in US political, economic, and cultural history (Black 2000; Kashi and Watts, 2010; Sabin 2004; Salas 2009). Multi-disciplinary scholarship has tracked the representational practices, persuasion strategies and symbolic pervasiveness of the oil industry through the appropriation, translation and redistribution of various discursive texts. Oil, as it is imagined through texts such as film, public art, documentaries, war propaganda, and photography, produces discourses on both the oil industry and on capitalism. Generally, this work confronts oil as an unassailable fact, showing that discourses produced by the oil industry have been successful in producing 'oil subjects'. Examples from the literature discursively produce social and political understandings of oil and oil practices. The following section reviews this literature and focuses on methodology, source textual material and on discourses produced. I then discuss Lefebvre's production of space and how it was useful is discussing the normalized practices of oil use.

\section{Discursive Conceptualizations of Oil from Literature}

The following literature examines ways in which oil was symbolically established as historically 'American'. For example, in times of perceived crisis, the oil industry referred back to a "conjured primordial existence" (Barrett 2012; 413). Ross Barret highlights two 
examples where discourse archaized oil as a timeless masculinist practice. Her first case, a statue called 'The Driller', commemorates the Drake 1859 oil well strike in Titusville, Pennsylvania. It was commissioned by Standard Oil in 1904. This was at the turn of the century when the oil industry had an uneasy 'boom and bust' identity and “...traditional constructs of self-restrained bourgeois masculinity were dramatically undermined ... by corporate restructuring of the economy, growing working class political agency and the new activism of the middle-class women" $(2012 ; 414)$. Another example Barrett examines is the 1934 World's Fair where Sun Oil commissioned an exhibition 'The History of Oil and Natural Gas.'. In a historical context where oil use was being questioned as wasteful, the exhibit showed murals where Native American extract and use oil in a 'natural' and 'sustainable' practice. These murals served to produce a broad and linear history where oil has always been used on an 'as needed basis' and had a natural use relation with human consumers. Further, in both representations oil is depicted as America's driving force toward technological advancements (2012). In effect, these representations shaped the public image of oil and at the same time addressed concerns of capitalism. Tropes for promotional discourse were being long-lasting: "oil as timeless", "oil as abundant", boom and bust industry as an age-old venture, and oil as an external component to a natural past. In the case of the Driller, the location is also affected, “...(the statue) models a willful command over the natural landscape that visualizes the complete harnessing of the dynamic material of oil through extractive labor" (2012; 409).

Frederick Buell takes a literary approach and uses various written texts to track how throughout history, oil has two partnering motifs- exuberance and catastrophe. Some texts reviewed included fictions by Upton Sinclair, Mary Shelly, Rebecca Harding Davis, 
Whitman, Hart Crane, Sinclair Lewis, and then nonfictions by Tarbell, Yergin, Marx, Vaclav Smil, William Catton, Barbara Freeze, Leo Marx, Sonia Shah, David Nye, and others. Buell discusses how the understanding of energy cannot be understood separate from an 'energy system' which requires 1) the material resources, 2) the associated energy technologies, and 3) the cultural conceptions of that energy. Further, energy systems are always understood in relation to previous or other existing energy systems. Buell tracks how oil symbolically defined itself against the previous era of coal with a discourse that leaned toward exuberance (as opposed to catastrophe) (2012). Oil, over coal, was able to take more socially fluid forms like light, travel, and expansion. Coal's cultural conceptions seems more rigid tied to pollution, labor abuse, working class immobility $(2012 ; 283)$. Oil is not devoid of crisis scenarios such as spills, peak oil, economic risk and chance. However tension between use and crisis has been normalized in popular conceptualizations. Buell discusses the modern catastrophe/ post-apocalyptic ability to counter oil's entrenched tradition of exuberance by offering landscapes of scarcity (2012). This is an example of how capitalism can adapt itself to various crises that arise: oil prices, overproduction, boycotts by oil cartels. Further it is an example of how discourse can normalize practices that are both contradictory and dangerous.

Stephanie Le Menager takes an 'object oriented approach' in discussing how oil shapes perceptions of the 'natural' world (2012). Le Menager examines how the world's largest archive of Pleistocene fossils are preserved atop the Salt Lake Oil Field in L.A., the world's largest urban oil reserve. This is an interesting case because of its setting; oil use has directly contributed to both L.A.'s 'ecology of freeways' and L.A.'s 'architecture of the fantastic' $(2012 ; 378)$. These tar pits become a specific organization of material cultures with an indirect narrative: life (indicated by the fossils) will pass with time but oil will stay. 
Le Menager states that this preserved urban tar pit creates a sensory regime (described by Foucault), as it defines the origins and relations of things through visualization $(2012 ; 387)$. At the same time, the tar pits now cannot be seen as separate from the fossil beds. For Le Menager, the tar pit is a discursive technology. This partnership between oil pit and fossil bed creates a specific ecological knowledge. In other words, the oil and practices of oil consumption are discursively embedded in a long standing fossilization past.

Sarah Frohardt-Lane analyzed World War II American propaganda to find a conflation between the oil consumer and a good US citizen (2012). Notably, while messages encouraged proper driving habits and gasoline conservation, driving was never encouraged to be given up completely during the war. Instead representations, "...portrayed driving as an integral part of American life" (2012; 338) and discouraged other forms of transportation. These energy discourses worked in tandem with discourses on the nation - as driving supported the war effort, and the gendered household - as the driver was portrayed as man driving the 'traditional' family.

The authors summarized above establish that petroleum cannot be separated from the evolving conceptions of life, nature and history. This follows the argument of geographer Mathew Huber who has argued that dramatic shifts in energy use have coincided with the dramatic social shift toward capitalist social relations or the reproduction of life under capital (2008). Further, these conceptions do not allow us as humans to reimagine life that does not center around us as a species. This, to many geographers and other thinkers, would be the conceptual starting point for sustainable energy use and sustainable living design. 


\section{Discourses on Everyday Practices of Oil}

In contemporary discourse, the oil industry is conceptualized as a stable, capitalist commodity (Pendakis and Wilson 2012; Musiol 2012). That has not always been the case. Hanna Musiol analyzes the 1934 novel Sundown by ‘tribal historian’ John Joseph Mathews where oil is struck on the Osage reservation in Oklahoma. In a context where oil extraction is chaotic with local forms of inconsistent regulation and unequal wealth distribution, Musiol re-materializes, historicizes and reterritorializes an account of oil before human and natural resources became socialized by colonial powers. "Oil gains its force because colonial institutions and legal frameworks imbue it with power and render rampant overexploitation of Osage wealth acceptable" $(2012 ; 372)$. This is a key characteristic of modernity; oil and oil extraction have been produced as social. Oil becomes: commodities (cars, fashion, cosmetics), "magical" gushers on the prairie, environmental pollution, and all the things that suddenly appear on the Osage reservation that are "made, bought or consumed by oil or oil wealth" (Musiol 2012; 366). Watts (2008) describes this as a 'double movement.' Oil extraction can simultaneously produce social stability in American industrial centers and cultural fragmentation at the sites of extraction- as seen on the Osage reservation (Musiol, 2012; 360). Musiol argues that in the time that Mathews wrote the text, there were new forms of labor organization and control and new legal and political interventions that increased the power of the state while also benefiting the large oil companies. Further, resource extraction of this type should not be seen as a stage in capitalist consolidation but an ongoing project of colonization (Musiol, 2012; 371). Political ecologists Michael Watts and Nancy Lee Peluso similarly wrote that oil continually gains its power from colonial 
institutions and legal frameworks allowing it to overexploit local resources and wealth (2001).

Patchett (2012) critically analyzes aerial photos of the Canadian tar-sands. Here Patchett finds that when photographed, the regional histories and local interactions between the oil industry and social communities are seen through a restricted frame. In this case, the aerial photo's vantage point is so high that the problematic oil extraction practices become neutralized. Patchett theorizes that a deeper investigation would show how visual texts are used in the production of meaning for the oil extraction landscape(s): consumption in the surrounding urban centers and transportation corridors, the extraction and refinery process, and towns on the rural fringes of extraction (2012). Pendakis and Wilson describe the consequences of the singular frame of photography, "The problem of visualization, ... is not specific to oil, but one politically structural to a system that is at once spectacularly consumerist and fully globalized on the level of production; Oil is, in this sense, dangerously literalized, wrongly conceived as simply coextensive with a highly simplified figure of its own productive apparatus" $(2012 ; 4)$. Here, oil has been domiciled to a simple equation, “...oil $=$ oil, ... or $\mathrm{A}=\mathrm{A}$, while in fact $\mathrm{A}=\mathrm{B}+\mathrm{C}+\mathrm{D} "$ (Pendakis and Wilson 2012; 4). In other words, the visualization of oil cannot reveal the complexity or controversial nature of its production or use. The singular perspective on oil spaces is problematic (Le Menager 2012; Pendakis and Wilson 2012; Zuck 2012). It is the image that maps out the economic life of our carbon combustion society and it is the image that flattens out the complexity of spatial political relations in the society. Biemann and Pendakis add, “... this level of abstraction in the representation of oil as yet another way to keep it firmly in the hands of market dynamics, a remote and inaccessible entity, supposedly too big and complex to grasp for the average 
citizen" $(2012 ; 8)$. Needed is an index of what is absent in the photos: the relocation of populations as a result of big money flowing into an impoverished area, or the nondemocratic decision making processes of oil regimes (Zuck 2012). And the decisions made about oil as a resource have never been made democratically because it was constructed as a complex landscape, too vast and interrelated for a single community to be voicing a critique.

\section{The Production of Space - Discourse and Geography}

The examples from the literature reviewed above show that oil is not only the object of geopolitical conflict and territoriality, but also that its consumption allows for the possibility of specific spatialities. In a material sense, it is the natural gas that heats individual homes and the gasoline that powers suburban commuters, it is what allows for the construction of LA freeways (Le Menager 2012). But it is not just material. Oil discourse disciplines the ways of living, thinking and feeling - a mental and social space. Oil then is constitutive of what Lefebvre called the social production of space. Lefebvre approached the production of space and its ability to constitute the discourse that governs its production, on both the material lived-in space, and the conceived or representational space (1991). It is a unitary theory to incorporate physical, mental and social space that assumes that space is produced through practice in the sphere of everyday life. While both Foucault and Lefebvre discuss power and discourse as a productive force in society, Foucault is concerned with the disciplining of bodies, and Lefebvre is concerned with the governing of everyday practices. Both are useful in theorizing my project due to the decentralized notion of power for Foucault (1972 and 1978) and a decorporatized notion of power for Lefebvre (1991). A pervasive understanding of power is helpful with the researcher's problem of causality. 
While Foucault was reticent to discuss unidirectional causality, Rose has acknowledged the need to name a social site as an authoritative source for discourse (Rose 2001; 158). My problem is the reverse. I am analyzing primarily only a single source, the largest multinational company in the world at the time, Standard Oil New Jersey. The temptation then is to freely give discursive power to SONJ with the assumption that if the company produced it, it must have had an effect. A challenge will be not to ascribe causality of change or transformation but rather simply describe the transformations happening in SONJ and attach them to a larger discussion of oil at the time. I believe Lefebvre's theory, the production of space, is useful here. In chapter 4 , the question of rural and/or small town significance is addressed when I argue that representations of rural extraction sites are key in the oil consumption practices in an increasingly urban post WWII life. SONJ is not the source of discursive power, it is the disciplining power of representational space. 
CHAPTER III

THE SONJ PUBLIC RELATION DEPARTMENT HISTORY AND THE 'HUMAN' ASPECT OF OIL

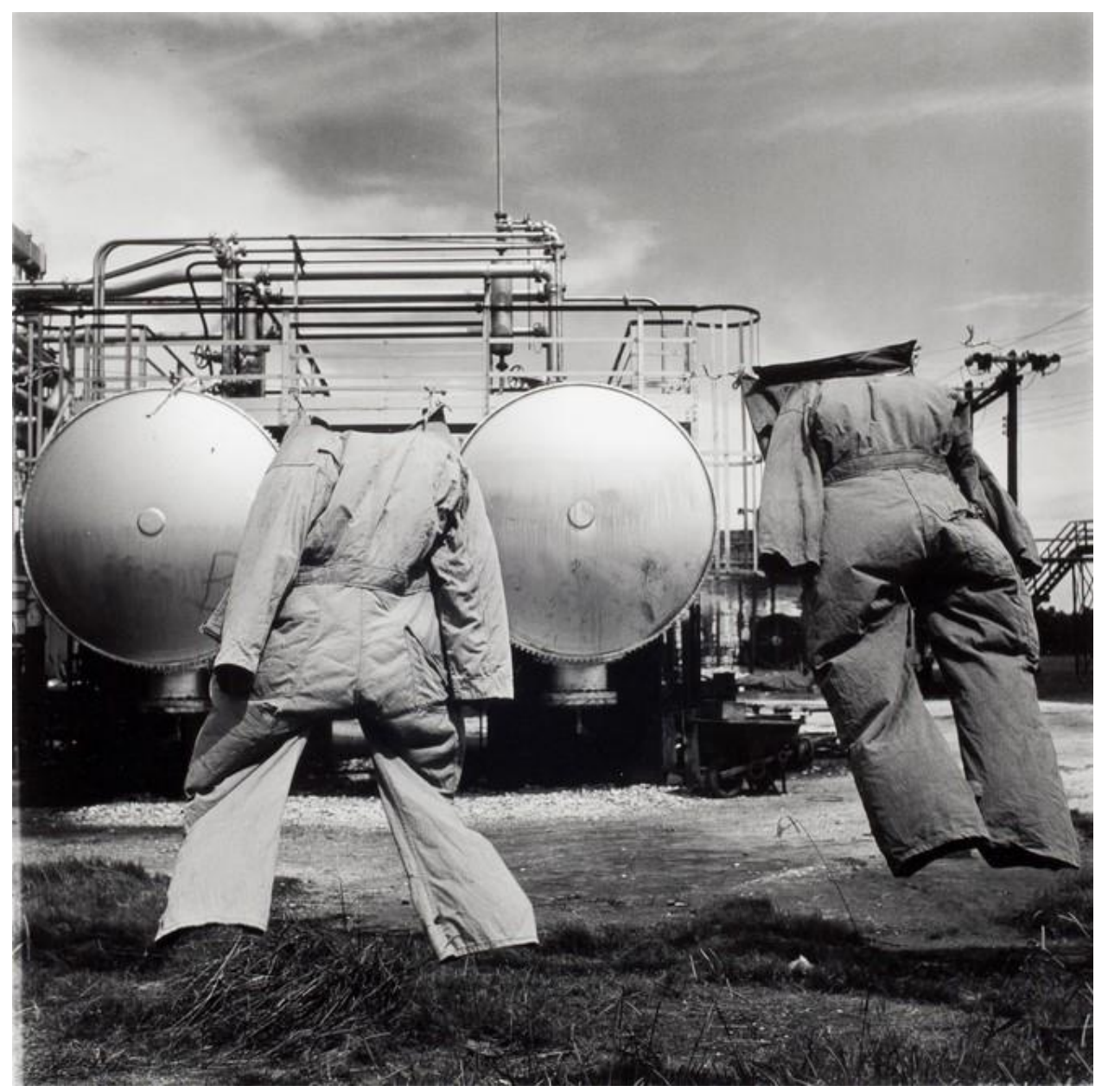

Image 1. (Corsini, 1946. Refinery workman's overalls hung on the line to dry. Special Collection, University of Louisville: \#37832) 
“...industry, from top to bottom, consists of people whose efforts and skills are the basis of productivity. [The Standard Oil photographers] feel that people and not the machines they work with are what is important in our industrial civilization" (Roy Stryker as quoted by Plattner, 1983; 18)

The photograph above (Image 1) was taken by SONJ photographer Harold Corsini in Baytown, Texas outside a large refinery. The quote is by the SONJ photograph file project direct, Roy Stryker as he describes the photo project. Corsini's photo is referenced by writer Steven W. Plattner in his book, Roy Stryker: U.S.A., 1943-1950, as an example of how the SONJ photograph collection was uniquely able to insert a 'human element' in an otherwise 'technical' execution of industrial photography $(1983 ; 11)$. The collection of over 80,000 photographs documented compelling topics with indirect and tenuous connections back to the oil industry: truck stops in New York, a traveling circus in Pennsylvania, and a rodeo in Montana. As a result, the Standard Oil New Jersey collection has not been easily classified by those who have written about it (Keller 1986; Plattner 1983; Larson, Knowlton, and Poople 1971), with each approaching the project from different perspectives. Keller, a photography professor, was aware of the notion that photographs are culturally produced texts with political implications. In his work, Highway as Habitat: A Roy Stryker Documentation, he is conflicted, calling the collection a 'promotional public relations project' and in the next paragraph calling it a 'documentation of American culture like no other' $(1986 ; 3)$. Plattner makes the distinction between 'public relations' and 'advertisement' - photography as art and as documentation being well within the purview of former, untainted by the latter $(1983 ; 14)$. Larson, Knowlton, and Poople (1971), in a SONJ funded history, feel less a need to classify the project and simply lists it as an initiative 
among many the public relations department took during the same period, to inform the public of the SONJ company' (1971; 631).

The discrepancy in classification comes from a desire to view project director Roy Stryker in a 'visionary' role, unimpeachable and untainted by a corporate desire to sell product. The SONJ photographers were also loyal in this impression of their project director. Here is Rosskam describing Stryker in a 1945 letter.

He is not a photographer. He is not a writer. He is not strictly an editor. He has a tendency to blush when ART is mentioned. And many would argue if you said that he is an administrator. He is, more than anything else, a man with a vision, which he realizes by sending people out into the field so that they may send him back his vision in thousands of little fragments together in such order as to total a broad image and intention. (Rosskam letter. 14 April 1945. Special Collection, Ekstrom Library, University of Louisville)

There is archival evidence to support a distinction between photo director Stryker and the photographers from the "retail" aspect of the public relations department. In a document authored by Freyermuth, Stanley, and Stryker, "The Work of the Photographic Department As It Appears After Six Months Experience”, a division of roles within the public relations department is defined. Under a heading titled 'Distribution', “...the photographic department is not equipped to undertake single-handedly the distribution of its product (photographs)... The placing of pictures should become, is bound to become, the responsibility of the whole Public Relations Department” (1944). Based a review of internal documents, evidence shows that Stryker less likely to organize a press release, an exhibit, or coordinate with media outlets. These tasks were usually done by Freyermuth, Stanley, Schackne or Maas (positions shown in Table 2). Stryker was focused on creating what he called 'pictures stories' of oil as reference material for research. The picture stories were 
multiple photos of the same topic or subject matter. For example, Vachon wrote Stryker in 1944 when he is in eastern Venezuela, that he had great shots of small flat boats on a river that were used to transport barrels of crude from extraction well to port. However, Vachon did not finish the picture story on river transport because he was unable to travel upstream to take photographs of where the boats were first loaded (Vachon letter March 29, 1944). Stryker writes in response and asks him to travel back to the river to complete the story (Stryker letter April 9, 1944). It is clear that Stryker's goal was to create an exhaustive file for reference purposes rather than images for a compelling promotional campaign. However, other members of the PR department would look for ways to disseminate those photos for public relation goals.

As a result, this archive is a heterogenous mixture of genres that differ in content, style and structure. The genres have distinct uses in the conception, production, dissemination, consumption, and preservation of the photographs. Comparisons and discrepancies between genres are fertile sites of analysis. Therefore, this thesis does not necessarily categorize the SONJ collection as purely propaganda, art, journalism, or documentation. Rather I discuss how those categories attach themselves to preconceived assumptions, beliefs, background knowledges and common sense notions about the different archive genres. The SONJ collection and its distribution is there for a complex site in the production of a culture of petroleum use in the U.S. This chapter contextualizes to the SONJ public relations department using oil history literature and archival correspondence. First, I review a brief history of the public perception problem of SONJ following a scandal that questioned a war time relationship SONJ had with the German chemical company IG Farben. Second, I introduce 'exhibitions' as one of the photograph distribution mechanisms found in the SONJ 
archive and in doing so will show how multiple genres can be used to analyze a single moment like the organizing and curating of an exhibition. Lastly, I end the chapter with a defense of the archive as a container for analyzing oil discourse.

\begin{tabular}{|ll|}
\hline George H. Freyermuth & - Manager of first SONJ PR Dept. \\
Robert T. Haslam & - Director of first SONJ PR Dept. \\
Carl Maas & - Art consultant retained by SONJ \\
Earl Newsom & - Public Relations Consultant hired by SONJ \\
Elmo Roper & - Public Opinion Pollster \\
Roy Stryker & - Photograph Project Director 1943-1950 \\
Stewart Schackne & - Newsom associate hired by SONJ PR \\
Edward Stanley & - Newsom associate hired by SONJ PR \\
\hline
\end{tabular}

Table 2. Key Persons in SONJ Public Relations.

\section{1) A Scandal and the SONJ Public Relations Department}

Mr. Roper has presented to us some X-ray photographs of the public mind. They show that, however healthy the Standard Oil Company may be in many respects, it is currently suffering from the effects of an acute attack of "Arnolditis." (quote marks in original) (Earl Newsom letter to SONJ board, Stryker Papers, 1942, November 2)

The 'Arnolditis' that Newsom references is a light-hearted description of the problem of public perception experienced by SONJ after Assistant U.S. Attorney General Thurman Arnold accused Standard Oil New Jersey of collaborating with the German chemical company IG Farben during WWII. The two companies had a pooled patent for synthetic rubber approved by the U.S. patent office in 1929. At that time, a standing agreement was made for SONJ to not develop a process for making synthetic rubber, and in exchange IG Farben would not market its petroleum-based products in the U.S. Arnold's accusation was that this cartel agreement was causing a rubber shortage during the war after the U.S. lost its 
natural supply of rubber in the south Pacific. Arnold implied that the shortage could have been prevented and could have saved American lives. Arnold explained that the, "sole motive of the Jersey-Farben cartel was for Standard Oil to secure a protected market, eliminate competition, restrict world production in order to maintain control" (Larson, Knowlton, and Poople 1971; 435). There were Senate Committee hearings in March and April of 1942 that were heavily publicized. Then senator and committee chair Harry S. Truman was quoted in Newsweek saying, "I think this approaches treason" (quoted by Plattner, 1983; 12). A case was also filed against SONJ in the Antitrust Division of the Department of Justice. However, the Senate investigation halted and the anti-trust case was dropped after Secretary of Commerce Jesse Jones testified that a similar synthetic rubber process was considered by himself and president Roosevelt prior to the war, but was dropped due to the large expense it would require (Larson, Knowlton, and Poople 1971; 451). Despite SONJ no longer being solely responsible for a rubber shortage, the public opinion of the company suffered.

In a thirteen-page letter to the SONJ board, consultant Earl Newson summarized the Roper polling findings in a numbered list (Table 3 ). The letter is fantastically diplomatic. Newsom navigates the political climate, the Arnold charge, and a knowledge that his audience was a corporate board that was famously closed off and obtuse to public inquiry. The letter sketches out a purpose and mission for a new public relations department. Newsom suggests practices of transparency for handling the media. He advocates an intentional bolstering of relationships with government officials. Newsom sells the idea that a public will come around to trust a large company if they see that the company is doing right. To a contemporary understanding and skepticism of public relations, the letter seems 
simplistic and naïve, and drips with advertising cliché rhetoric. However there is evidence to suggest that the company invested in Newsom's plan with some degree of sincerity. The public relations department initiated several promotional practices that again seem odd to a contemporary frame of corporate behavior. The department sponsored a traveling art show

1) Most of the people of this country think that all Standard Oil Companies are all the same thing.

2) Most of the people look upon you as the largest oil company in America.

3) Your size does not in itself prejudice people of the country against you. They even look upon your bigness as a good thing for the general good of the country.

4) While they do not dislike you for being big, they have the impression that you have been greedy - and that through you Germany got the best of America in a big business deal.

5) People do not know much about you. The do not know about your inventions or about your contributions to the war effort.

6) Among the country's outstanding corporations, people have a less friendly feeling toward you than toward the others.

7) This general attitude is found not only among those in the laboring class, the uneducated, the poor. Business men, wealthy people, professional people, have the same feeling about you.

Table 3. Earl Newsom Public Poll Summary for SONJ Board November 2, 1942. (Source: Stanley Letter. 1942. Stryker Papers. Special Collections, Ekstrom Library, University of Louisville).

of painters, funded a three-volume history of their company to be written and mass published, produced education manuals for teaching oil in schools, mass produced the company's annual reports and sent them to media outlets - changing the language to suit a non stock holder audience, made documentary films, and hosted 'Jersey Roundtable' 
discussions with members of academia who were invited because they were particularly critical of the company (Larson, Knowlton, and Poople 1971; 628-661). Larson, Knowlton, and Poople calls this a period of 'self education' for the public relations department (1971; 628). The photographic file was created in this context of 'self education.' The photos were then used in the wide range of promotional material to bolster the larger public relation goals. It was Edward Stanley who reached out to Roy Stryker because they both had worked together in the government office of war information (OWI). Roy Stryker was brought on as director of the photography department because of his acclaimed success with the Farm Securities Administration (FSA) photographic project where he coordinated a team of photographers to capture over 100,000 photographs over the time span of 11 years to bolster support for New Deal farm legislation. Striker hired many of the same photographers from this previous FSA project in the SONJ project (Plattner 1983). Table 4 lists SONJ photographers.

\begin{tabular}{|lll|}
\hline Berenice Abbott & Russell Lee * & John Vachon *+ \\
Charlotte Brooks & Sol Libsohn & Todd Webb \\
Esther Bubley + & Lisette Model & \\
Harold Corsini + & Gordon Parks * & * FSA Photographers \\
John Colier * & Martha Roberts & + Photographers \\
Arnold Eagle & Edwin Rosskam *+ & mentioned in thesis \\
Morris Engel & Louise Rosskam & \\
Elliot Erwitt & Charles Rotkin & \\
\hline
\end{tabular}

Table 4. SONJ Photographers.

\section{2) Genre Introduction - Exhibitions}

Appendix B provides a list of exhibitions found in the archive. It is not exhaustive of all the SONJ exhibitions. There have been perhaps hundreds of galleries that have displayed the 
photos of the Standard Oil New Jersey Collection. Standard Oil's Public Relations and Archives departments curated some exhibits. Other galleries were curated in conjunction with SONJ to fulfill a specific thematic request. And more exhibits were independently curated with an alternate purpose other than specifically show-casing the oil industry, such as displaying the work of a photographer or picking photos from a specific location. The majority of exhibitions in Appendix B were what SONJ called a 'general selection.' The photos used were diverse in terms of content, photographer, location, and segments of the oil industry. While there is no full list of exhibits, I have compiled this list using multiple documents from the archive at University of Louisville's Special Collections that exemplify multiple genres: correspondence letters, press releases, and accompanying exhibit literature. Information on each is dependent and limited by the type of documents found.

The first exhibit put together by Roy Stryker at Standard Oil was "Men of Oil" at the Franklin Institute, a science and technology museum in Philadelphia. It included 69 photographs by eight different photographers. The exhibit displayed portraits of laborers in various segments for the oil industry at both foreign and domestic locations. The purpose of the exhibit harkens back to one of SONJ's original goals laid out by Newsom - showing the American public the positive contribution the oil industry was making for the war effort (Table 3). In the Franklin Institute's press release, the exhibit was a "tribute to men and women working in American oil who are implementing our fighting men petroleum products for the wartime effort" (exhibit literature, 1944). However it is clear that "Men of Oil" was meant to do more than honor oil workers. Also quoted was Vice-president of Standard Oil in Philadelphia, E.H. Collins, 
"From under the ground all the way to its final use, oil is generally out of sight - in pipes or massive steel vessels. There is a thrilling, almost mystical drama in the massive forms and architectural geometry through which the oil invisibly flows. There is an alertness and capability in oil workers which is quickly sensed by the visitor. It is quality and setting, at the refinery and in other phases of the oil business, that provides the central theme for the exhibition." (Men of Oil press release, 1944. Stryker Papers. Special Collections, Ekstrom Library, University of Louisville: Louisville, $K Y$.)

Collins does not treat "Men of Oil" as wartime propaganda but as a sincere attempt to educate and fascinate what SONJ believed was a public ignorant of the technical workings of the industry. Somewhere between photo as art, photo as educational text and photo as propaganda, this exhibit is an instructive introduction of how the public relations department would continue to produce and distribute the SONJ collection.

In April 1946, G.H. Freyermuth writes a Professor Moriam at Harvard Business School to inform him of the exhibit "Architecture of Oil" that will be shown on Harvard's campus. "The show will consist of thirty-two large photographs. The subjects covered include some of "our working men's housing in Venezuela", a few pictures on the building of a derrick, a considerable number of pictures of smaller buildings such as testing units, laboratories and pipeline structures" (Freyermuth letter, 1946). Included in the letter was a narrative of how the idea of the exhibit was first conceived. Freyermuth developed with the theme while discussing industrial design of oil refineries with a Professor Marcell Breuer at M.I.T. some years before. Freyermuth then invited Moriam to attend a presentation that he would be giving Breuer's class in conjunction with the exhibit. This is one of the few exhibitions where the initial start of curation and distribution is documented. In the case of "Architecture of Oil", it was a personal relationship Freyermuth had previously with members of elite higher education institutions. If one of SONJ's goals was to reach middle to upper class educated populations, this was a perfect opportunity. Freyermuth hinted that his future goal 
was publishing some photos in the magazine "Architectural Record" and to then circulate the exhibit in other architectural design schools. The exploitation of casual relationships of corporate oil allowed for the photo project to be presented to a class of architects soon to join the work force. It is important to point out that Freyermuth does not believe he has insidious motives. His tone reveals that he treats this project something like a civic duty or service motivated by a real admiration of the architectural forms depicted in the photo panels.

Photo exhibitions also had the public relations potential for damage control. Carter Oil was a subsidiary of SONJ. In February 1947, Carter Oil wrote the public relations department office in Rockefeller Plaza New York and requested a traveling exhibition of 50 to 60 photo prints that could be screened throughout the "Carter Oil territory". "Because of the wide public interest in photography, such an exhibit would have a tremendous potential circulation among individuals, ranging from the refinery stillman to the college professor and to the bank president. Such exhibits would further develop a friendly feeling for Carter in its territory" [sic] (Carter letter, 1947). Their idea for circulation was to use camera clubs who would handle and screen the prints independently. The company had enlisted two members of the Tulsa Camera Club to help them initially but explained that there were "at least thirty well established camera and photography organizations in our operating states ..." (1947). The archival documents do not provide enough information to know if this request was approved and acted upon in any manner close to what the Carter Oil Company had hoped. Nor is it possible to know who saw this traveling exhibit and what effect it had on that audience. Revealed is the internal workings of a multinational corporation who had the chance to awkwardly test out a new media and new media platform in the multitude of different regional geographies in which it operated. As Carter Oil vied for its project's 
approval from the public relations office in New York, it sounded over reaching and overly optimistic. It also sounded naïve and sincere.

\section{"Artists are people too"}

On June 7, 1946, Earl Newsom responded to a letter written by Edward Stanley that was circulated among members of the department staff. In Stanley's original letter, he had enthusiastically conceptualized a new archetype, that businessmen would "become zealous experts in the realm of ideas" and that they "hire artists to portray the ideas to the masses of people" (Stanley letter, 1946). Perhaps surprisingly, Newsom, the public relations consultant, disagreed with Stanley. He countered that businessmen do not have time to be experts in the realm of political ideas and "that artists are not carried away by ideas through the process of having been sold to them as ideas" (Newsom letter, 1946). Newsom was basically saying that the artistic process cannot be bought. This seem rather ironic considering the practices adopted by their department at the time. Newsom ends his letter with the following.

The way to start (being a good businessman) is to make democracy workbetter than communism or socialism or any other system. This can be done only if industrial democracy meets the challenge of the age and takes progressive leadership. Democracy can be made so vital and persuasively good that artists will flock to it of their own accord. Artists are people too.

(Newson Letter, 1946, June 7; Stryker Papers)

It does not seem like this internal debate about art and governing systems had any guiding context besides their own recent successful efforts in producing promotional material for masses of U.S. audiences. It is an interesting moment because rarely do the nuanced 
theoretical views of large corporation employees get revealed. Critical writers who analyze global capital and large multinational companies like SONJ tend to portray them as flat perpetrators of accumulation by dispossession (Harvey, 1974) and bureaucratic facilitators of colonial expansion (Yergin, 1991). Accumulation by dispossession is a term used by Harvey to described the concentration of wealth and, in the case of oil, the concentration of territory and resources, from public accessibility into the hands of the capitalist class. This archive is a perfect supplement for such critiques, analyzing SONJ in a more relational frame. The epistemology here is one that understands institutions like SONJ are constituted by complex and contradictory social practices which are then reproduced. Standard Oil New Jersey reinforces exploitive sociological practices despite having a visionary photography director and despite having what I have called a 'sincere' belief in art and/or democracy.

This chapter has contextualized the SONJ photo archive in a history of post WWII transition and in one of corporate scandal. The archive is unique in its conception because the practices of public relations were not yet established like they are presently. The documents of the archive have the potential to display interesting and significant juxtapositioning that I will make use of in my analysis. I have introduced one mechanism, the exhibit, as an example for how multiple archive genres are used together for analysis. I will use other mechanisms in my analysis. This sets up my analytical chapters with context and an establishment of terms. 


\section{CHAPTER IV}

\section{PRODUCTION OF OIL TOWNS, OIL COUNTRY, AND THE SCOPIC REGIME OF}

\section{AMERICANA}

While common narratives on post WWII American society's relationship to oil have focused on the expansion of 'big oil' companies, and the increase in geopolitical conflicts (Klare 2004, 2001; Yergin 1991), geographers in the literature have complicated this by showing the oil's growth to be predicated on the cultural and political practices of everyday petroleum distribution and consumption. Mitchell's book, Carbon Democracy examines how the physical infrastructure of oil, such as pipeline networks, tankers, refineries and filling stations, become conduits of social and political power (2011). Oil's materiality allows for (and limits) democracy as we know it (2011). Geographers such has Huber, have focused on how oil is constitutive of the social production of the cities and the infrastructures that make a modern American way of life possible $(2013,2009)$. Here, oil is viewed not solely as an empirical object or even a cultural production, but also a social relation under capitalism that effects how we think about the world and how we situate ourselves in space. The social production of space has generally focused on the urban (Harvey 1989; Lefebvre 1991). The practices of petroleum use and their role in the production of urbanized space has been written about by Huber $(2013,2009)$ and Frohardt-Lane (2012). But rural spaces of oil 
extraction have also been produced through discursive strategies. A recent example is the collection of aerial photographs (mentioned in chapter 2 literature review) taken by famous photographer Edward Burtynsky of the Albertan Oil Sands in 2007. Burtynky's photos of surface mines, refineries, tailing ponds and other human altered landscapes are beautifully executed and breath taking. However, critics have noted this beauty obfuscates the health and environmental risks of the polluted sites (Gismondi and Davidson 2012; Crang 2010). Because of Burtynsky's scale aesthetic, from a high aerial vantage, the images nullify toxicities and erase representation of the industry's destructive practices (Patchett 2012). Discursive implications of the politically ambiguous photos are: 1) to neutralize the politically controversial extraction practice; and 2) to normalize the scale of the world's largest industrial site (Patchett 2012).

In a similar critique, this chapter looks at oil's role in the production of rural and small town space in postwar America. This is not so much a geography of sites of oil production, but rather a reframing and reimagining of oil production sites, both oil fields and oil towns. I argue that the use of photographic documentation by SONJ at these sites produces a casual association between the oil industry and tropes of common Americana culture and small town values. This in turn produces a discourse of oil as ordinary, banal and uncontroversial. Corporate oil industry is realigned with the traditional modes of work, independence, and other American working class industries such as farming. This chapter is in two sections. In the first section I analyze two publications where SONJ photos are circulated, the Coronet magazine (1946) and SONJ's own Photo Memo (1945). The Coronet article called "Oiltown U.S.A." is a picture story of Tomball, Texas. The Photo Memo piece is a profile on Cut Bank, Montana. By comparing texts in the publications with texts from the 
original SONJ archive, I show how a particular geographic imaginary of oil towns is produced. The next section analyzes another Photo Memo and its profile ok Cushing, Oklahoma (1947) and something SONJ calls 'oil country', the peripheral space around oil towns. Here I use correspondence letters found in the SONJ collection between photographer Harold Corsini and project manager Roy Stryker to reveal discrepancies between how the images of Cushing were produced and how they were distributed in the publications. I conclude with a discussion on the implications of a produced space of oil towns and rural America as oil production sites.

\section{1) Oil Town U.S.A. - Representations of Tomball Texas and Cut Bank, Montana}
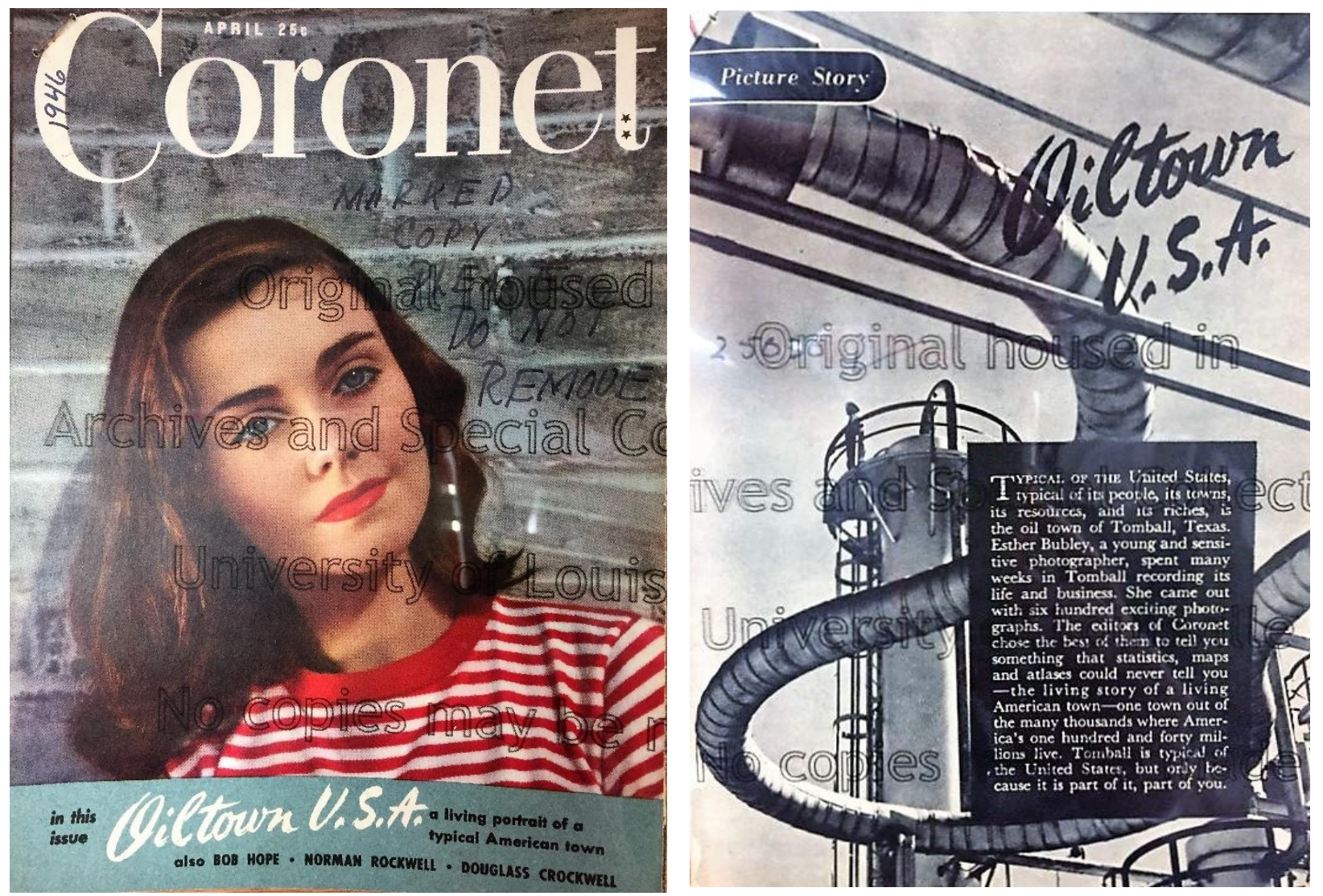

Image 2. (left) Oil Town U.S.A cover and Image 3. (right) Oil Town, picture story, title page Source: Michael Schinas Collection. Special Collections, Ekstrom Library, University of Louisville: Louisville, KY.) 
Caption (Image 3) Typical of the United States, typical of its people, its towns, its resoucres, and its riches, is the oil town Tomball, Texas. Esther Bubley, a young and sensitive photographer, spent many weeks in Tomball recording its life and business. She came out with six hundred exciting photographs. The editors of Coronet chose the best of them to tell you something that statistics, maps and atlases could never tell you - the living story of a living American town - one town out of many thousands where America's one hundred and forty millions live.

Tomball is typical of the United States, but only because it is part of it, part of you.

The Coronet was a general digest publication, owned by Esquire, that included cultural topics, celebrity stories, poetry, and advice columns. During the war it was marketed to women whose spouses were overseas on tour. Content consisted of lighter, less serious stories from the war such as pieces on soldiers hanging out in their down time, telling jokes and stories. After the war, the magazine continued with fairly heavy handed themes of American patriotism. Similarly patriotic, the feature piece in the April, 1946 issue was a 'picture story' on Tomball, Texas called Oiltown U.S.A. It consisted of twenty-five photos from SONJ photographer Esther Bubley taken while she was on assignment in May 1945. The picture story was formatted with one or two photographs per page, each with accompanying text. The texts are longer than a traditional journalistic caption. They reference the photos they are paired with; they also contextualize the town of Tomball with a broader historic and geographic scope.

The introduction (Image 3) presented a peculiar methodology for how the piece was written. It was proposed in the text that Bubley, a fairly well known photographer, just so happened to be in a small town outside of Houston for long enough to take 600 photographs. The town just so happened to be an oil town. The photos were then handed over to Coronet editors who simply selected 'the best' twenty-five. Coronet then sequenced the images and wrote an accompanying story. Curiously, neither Standard Oil New Jersey nor Humble Oil 
(the SONJ affliate company in Tomball), are ever mentioned. SONJ was a majority interests owner of Humble Co. at the time. It would purchase the company out right later in 1959. In 1973, the two companies merged and became Exxon. The lack of creditation and the hiding of Bubley's employer is curious because most the photos in the original photo file are marked as 'Humble Oil territory' by Bubley. Anonymity makes the intention of the article vague - is this a piece to promote oil or a piece to promote Tomball? Archival evidence reveals that the SONJ photographers chatted amoungst each other about the Tomball story before April 1946 (Corsini correspondence, 1946). Another photographer Harold Corsini was excited for his colleague's publication and wrote to the project manager Stryker about creating something similar. I have not found evidence that the SONJ public relations department approached Coronet for the story or assisted in the writing in any way. Potentailly, Coronet could have produced the whole piece like it is suggested. However, extra journalistic work, beyond what Bubley did in 1945, was clearly done by either Coronet or SONJ because more detailed information about the photographs is given in the article than what orginally was given in Bubley's captions. Regardless of the author, the piece checked off many of the goals that the public relation department originally set (Table 3 ) - to be known as relatable and dependable and to have the oil industry's contribution to the war effort recognized.

However, I will not focus on the intentions and actions of the public relation department, rather examine how their actions combine in a variety of ways to produce not only the physcial and social space of oil towns but also the set of signs and symbols that create meaning in those towns - the production of space. For example, the introduction (Image 3) makes use of scale to construct a collective understanding of oil, "Tomball is 
typical of the United States, but only because it is part of it, part of you" (image 3). Beyond the physical measurements of town, country, and body, scale works to create layers of interpretaion and association as a way to dissolve difference that would normally be demarcated if the reader had never been to Tomball or had no prior understanding of an oiltown. The concepts of scale and a citizen subject are constructed when Tomball is related to the rest of the nation.

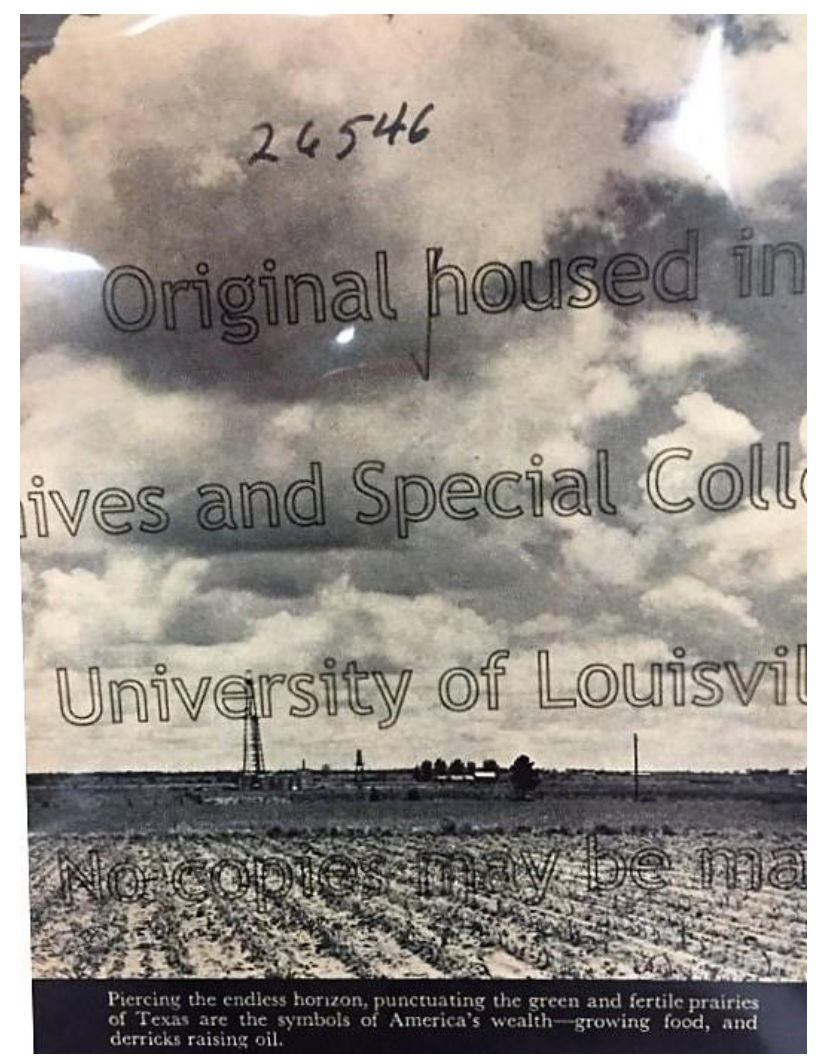

Image 4. Coronet Magazine, page 13. Caption - Piercing the endless horizon, punctuating the green and fertile prairies of Texas are the symbols of America's wealth - growing food, and derricks raising oil. (Coronet Magazine, 1946; 13) (Source: Michael Schinas Collection. Special Collections, Ekstrom Library, University of Louisville: Louisville, KY.)

Image 4 was the first page of the Tomball, Texas piece. The representation of Tomball as both a farming community and an oil field is introduced right in the beginning. 
The relation between the two industries was presented as common place. The piece repeatedly made this association to reinforce the narrative that farming and oil were not in competition, nor would oil impede on the ability to farm due to land reform or environmental hazards. A particular socioecological relation to natural resources was reproduced - that growing food and "raising" oil would make America wealthy if only the country's small towns continued to work and steward the fertile land. "Raising oil" was an odd word choice to reference the production or extraction of oil - it made the association with farming practices, raising produce or raising livestock, more natural sounding.

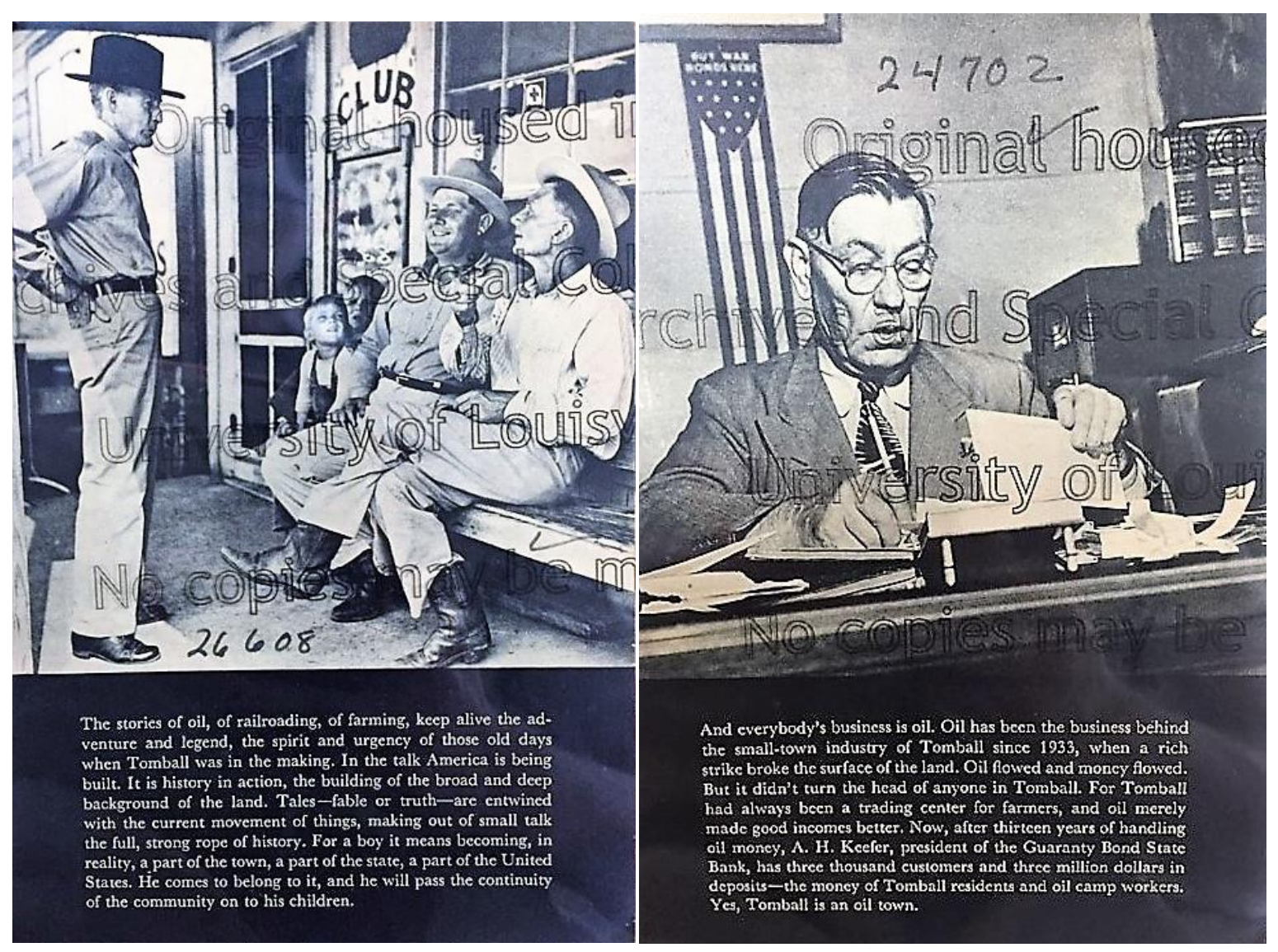

Image 5. (left) Oiltown U.S.A: page 17 and Image 6. (right) Oiltown U.S.A page 19 (Source: Michael Schinas Collection. Special Collections, Ekstrom Library, University of Louisville: Louisville, KY.) 
Caption Image 5: The stories of oil, of railroading, of farming, keep a alive the adventure and legend, the spirit and urgency of those old days when Tomball was in the making. In the talk America is being built. It is history in action, the building of the broad and deep background of the land. Tales - fable or truth-are entwined with the current movement of things, making out of small talk the full, strong rope of history. For a boy it means becoming, in reality, a part of the town, a part of the state, a part of the United States. He comes to belong to it, and he will pass the continuity of the community on to his children.

Original Bubley caption in archive: Street scene. Main street. Saturday afternoon. (\#26608)

Caption Image 6: And everbody's business is oil. Oil has been the business behind the small town industry of Tomball since 1933, when a rich strike broke the surface of the land. Oil flowed and money flowed. But it didn't turn the heads of anyone in Tomball. For Tomball had always been a trading center for farmers, and the oil merely made good incomes better. Now, after thirteen years of handling oil money, A.H. Keefer, president of Guaranty Bond State Bank, has three thousand customers and three million dollars in deposits - money of Tomball residents and oil camp workers. Yes, Tomball is an oil town.

Original Bubley caption in archive: Tomball Guaranty Bond State Bank. A.H. Keefer (\#29908)

The farming and oil partnership was continued in Images 5 and 6 where a history of the town's economy was given both from the prespective of a multi-generational group of residents on the street and from the local bank president. Quantitative account talleys and cumalitve holdings in dollar amounts showed how the industries worked together. Oil was seamlessly inserted into the town's history, countering the narrative of the oil boom town economy that was disruptive, inflated, and then was dissminated when the market 'busts' (Olien and Hinton, 1982). Interesingly, oil camp workers are segregated from the small downtown geography and separted from the histories of Tomball. However their money was combined in the local bank - a note again to counter that oil booms drain a town of resources without investing back in the town. Image 7 showed how the Coronet magazine again gave selective geographic information as it conceptually mapped a Tomball center where 
community life happened and then a Tomball outskirt where oil workers lived. This mapping made clear that the oil industry wa not intrusive. The SONJ photograph file contains all the photos of Tomball that Bubley took but were not selected fo the picture story. Photos of the oil camps and the pool hall where oil workers hung out were not used by Coronet.

There was another productive moment happening in the Coronet piece. History was concieved as an inheritance passed down through a gendered notion of growing up in a small town. Memory and space were both produced through a discourse of belonging and sacrifice. In one case, it was a younger boy who overhears an oral history of the town by older men (Image 5). I have included Bubley's original caption in this example to show that this narrative about history was written later. There would be no way to know what the topic of conversation was in this photograph unless Bubley had noted it eariler in 1945. Another set of examples are the two portraits taken on VE Day of older residents remembering those who had died in war (Image 8). The memory of Tomball sons who have passed wa paired with the victory of America in the war. It is intersting that the oil industry was separated from a histroy of small town loss and sacrifice, but was associated with the victory, “... the druggist, the grocer, the farmer, the oilman - made it (a WWII victory), as all of America made it". Mentioning oil with other Tomball professions produced an association based on class. Oil had from its start, an identity of greedy profiteering (Yergin, 1991; Olien and Hinton, 1982). Oilmen were thought of as transient and rough or violent. The Coronet piece discursively created a relation between the oil industry and small town values or working class morality. For example, oil made "good incomes better" (Image 6). And despite the improvements proveded by oil, Tomball was presented as preoccuppied in raising their 
children and not with wealth. So oil then was in the background, a natural part of everyday life, but not a dominanting force. And oil did snot counter a working class value of making life better for the next genreation.
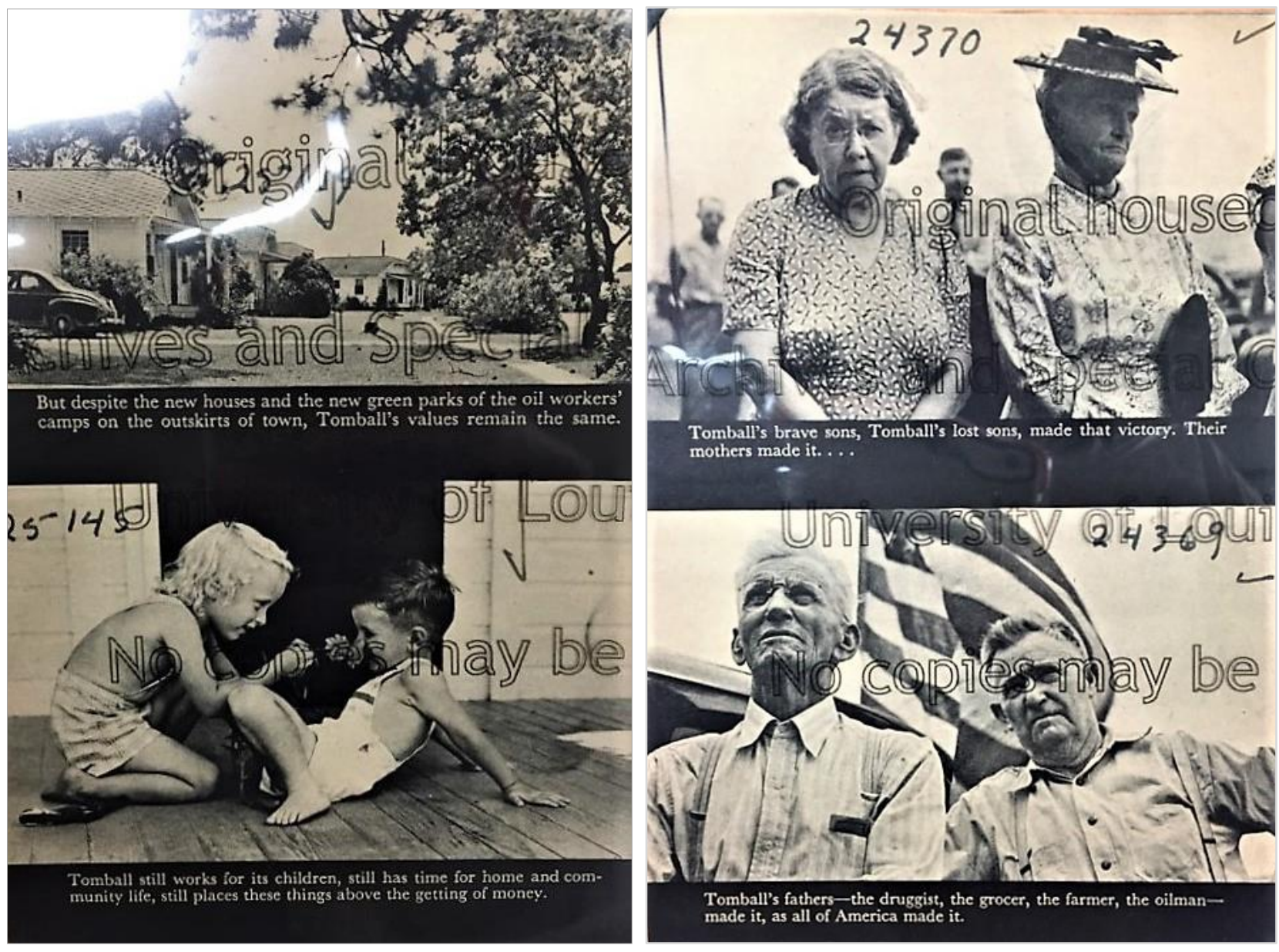

Image 7. (left) Oiltown U.S.A, Page 20 and Image 8. (right) Oiltown U.S.A, Page 27 (Michael Schinas Collection. Special Collections, Ekstrom Library, University of Louisville: Louisville, KY.)

Caption Image 7 (top): But despite the new houses and new green parks of the oil workers' camps on the outskirts of town, Tomball's values remain the same.

Caption Image 7 (bottom): Tomball still works for its children, still has time for home and community life, still places these things above the getting of money.

Caption Image 8 (top): Tomball's brave sons, Tomball's lost sons made that victory. Their mothers made it ... 
Caption Image 8 (bottom): Tomball's fathers -the druggist, the grocer, the farmer, the oilman - made it, as all of America made it.

The Tomball piece by the Coronet was a huge success for the SONJ public relations department. This was exactly how they had hoped their photos would be used. Using the background knowledge of the nationalistic pride in small towns, and the assumptions of moral values, the oil industry reinforced a discourse of oil as common, ordinary, and uncontroversial. This discourse produced a taken-for-granted partnership with agriculture, deescalated tensions around oil and class, and crystalized the oil industry as an embedded political institution in the everyday life of small town America. The Coronet story became the prototype picture story for the SONJ collection. Photographers carried around a copy of the publication with them so they could show oil workers at other site assignments examples of why they were taking pictures (Corsini Correspondence. 1946). Affliate companies wrote the public relations department and asked for the photographers to come and shoot their oil field like Bubley shot Tomball (Carter Oil request, 1946). Combining pictures of casual everyday life and unique scenes of Americana with the more technical content of oil extraction became a proven formula for SONJ photo projects. Again, I do not know exactly how the Tomball story came about, however it looks remarkedly similar to a story that profiled Cut Bank, Montana that SONJ did in their own publication, Photo Memo No 1, earlier in October 1945.

Cut Bank fit the a steretypical definition of an oil town that had experienced a 'boom'. While contextualizing the photos with a history of the town, SONJ presented the boom in a positive light. Cut Bank was struggling before oil and gas were found, and then thrived after a refinery was built. But its success was not solely attributed to oil and gas but 
also to farming. Just like the story on Tomball, the association with farming was reinforced with visuals of farm machinery next to oil derricks in a wheat field. Spatial decriptions of the refinery being "marvelously compact" and "the modern oil community, ... flourishing cheekby-jowl with a picturesque main street" created a mapping of oil practices that integrated with the town, but did not overpower it (see Image 9 caption).

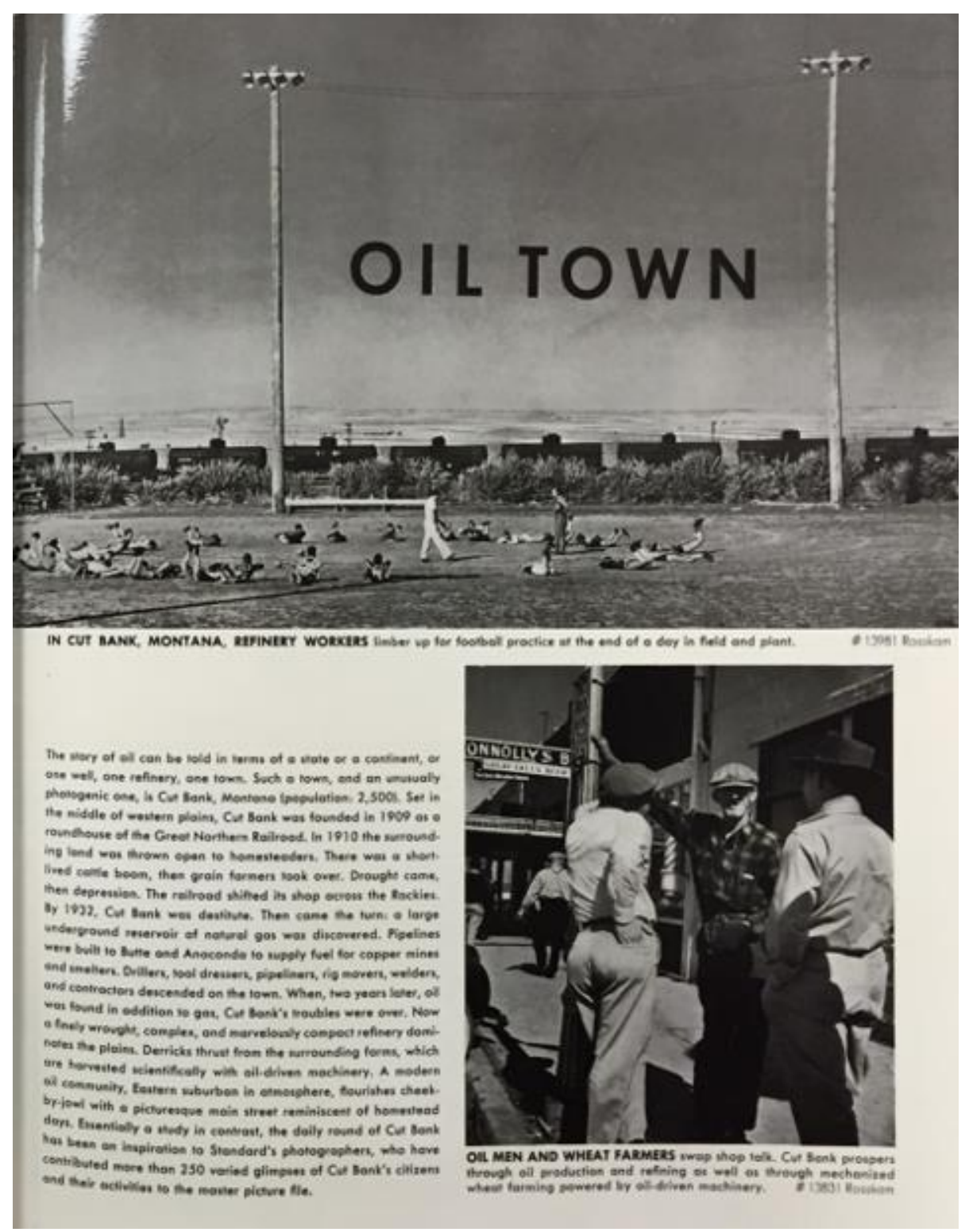

Image 9. Photo Memo No 1 - Oiltown (Photo Memo No 1. 1945, October. Schinas Collection. Special Collection, Ekstorm Library, University of Louisville. Page 13) 
Image 9 caption main text - “...When, two years later oil was found in addition to gas, Cut Bank's troubles were over. Now a finely wrought, complex, and marvelously compact refinery dominates the plains. Derricks thrust from the surrounding farms, which are harvested scientifically with oil-driven machinery. A modern oil community, Eastern suburban in atmosphere, flourishes cheek-by-jowl with a picturesque main street reminiscent of homestead days. Essentially a study in contrast, the daily round of Cut Bank has been an inspiration to Standard's photographers, who have contributed more than 250 varied glimpses of Cut Bank's citizens and their activities to the master picture file [sic]."

Image 9 caption bottom right: Oil men and wheat farmers swap shop talk. Cut Bank prospers through oil production and refining as well as through mechanized wheat farming powered by oil-driven machinery.

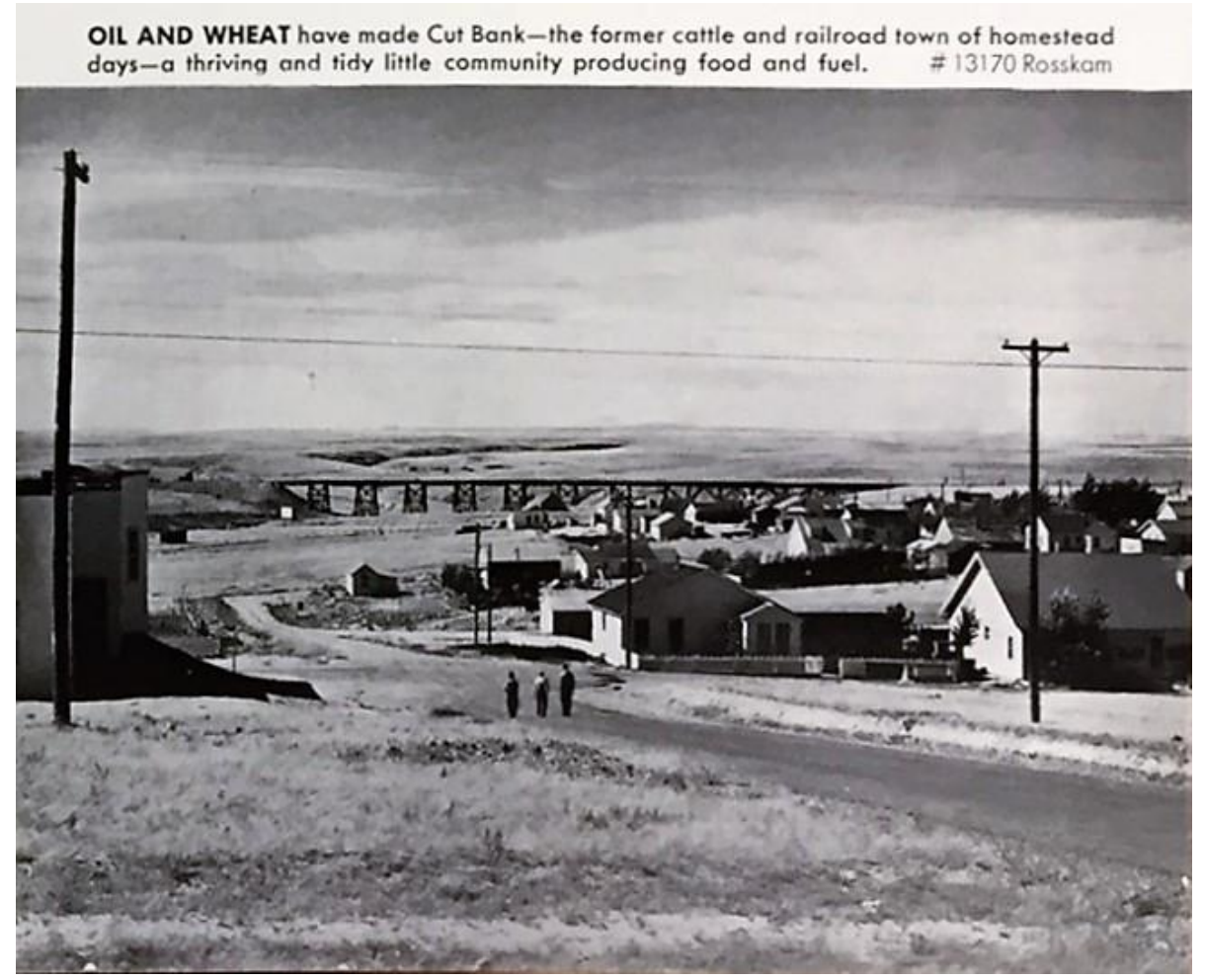

Image 10. Photo Meme No 1 - Oil and Wheat - Caption: Oil and Wheat have made Cut Bank- the former cattle and railraod town of homestead days- a thriving and tidy little community producing food and fuel. (Photo Memo No 1. 1945, October. Schinas Collection. Special Collection, Ekstorm Library, University of Louisville. Page 15) 
Image 9 showed a football team stretching as a train of oil tank cars rolled past in the background. The two things, the team and the train, were both familiar. However, their proximity to each other was peculiar and uncommon. This was enough to make an interesting photograph under the category of photo journalism. Photographers for the SONJ project, like Esther Bubley in Tomball and Rosskam in Cut Bank, were experienced in the field. Their desire was to create something visually interesting and worth documenting. They also had to satisfy an employer in SONJ whose business was oil. The results were these unique pairings of things, ordered in a way that assumed a natural association. I call this the scopic regime of the Americana. A scopic regime refers to how vision is socially constructed - what is seen and how it is seen (Rose $2001 ; 6)$. I argue that the SONJ project made use of a regime to pair things together that were familar enough to an American audience, and simutaneously could appeal to the unique and individualistic identity of Americana and small towns. Thus, oil towns were constructed as familiar but were still able retain their character despite their proximity to a corporate multinational industry.

\section{2) Cushing Oklahoma and the Production of an Oil Country}

The following section details how the rural spaces of both oil towns and oil fields were produced not only at the moment of photographic distribution like Tomball in the Coronet and Cut Bank in the Photo Memo, but also at the moment when and place where photos were taken. The correspondence letters between the project manager Roy Stryker and the photographers who were sent out into the field reveal some of the most glaring contradictions within the archive. These letters served as a general check-in between

employee and supervisor. They included travels arrangements, equipment and material 
needs, and payment details. These mundane back and forth letters reveal the process of production of the photographs, captions, and larger picture stories and the focus particular photo assignment themes. Sometimes, Roy Stryker would include specific items he wanted photographed, like 'signs', or 'hands' or 'machinery'. Other times there would be an idea for a picture story theme that Stryker would dictate and the photographer would then have some autonomy for how this project would get done depending on what they could find in the field. The letters were familiar in tone and often included personal opinions and observations that were not meant for a further audience. Given that none of the photographers had experience working in the oil industry, they were often alien to the nuances of everyday industrial practice and unaware of a troubled oil history. As a result, photographers wrote about their frustrations in the letters to Stryker. This included for example, political objections to photographing a moving worker camp for Humble Oil (SONJ affiliate in Texas) that would follow oil labor strikes, and a photographer's personal aversion for shooting inside of machine shops because they found the environment to be messy. I include segments from three different letters written in 1946 by photographer Harold Corsini to Roy Stryker. During this time, Corsini was in Oklahoma traveling from town to town and occasionally running into another photographer Edwin (Eddie) Rosskam. While the archive does not include an initial letter from Stryker that directs Corsini, it is apparent based on the correspondence that Corsini has been instructed to photograph a town that has experienced an oil 'boom' but has not since 'busted'.

Corsini Correspondence 1: February 26, 1946

"We ran across an extremely interesting town called Cement. Cement had been boomed about four times. It is a small cow town in the midst of an Indian reservation. There are wells around the town and lately they have crept right into 
town to nestle with the houses in a most photogenic intimacy. Carter has one or two gas wells here, but no production. This town could be the opposite of a picture showing good drilling towards conservation practices. Wells are scattered everywhere, even on school grounds. Now, I understand that pictures of townsite drilling are not too useful to you as they are one of the things that the industry is not too proud of, but I couldn't let this go by. After all, that is the oil industry, and besides it made damn good pictures. Why is that the bad things are so good to shoot and the good things so hard." [sic] (Corisni Correspondence 1946. The Roy Stryker Papers)

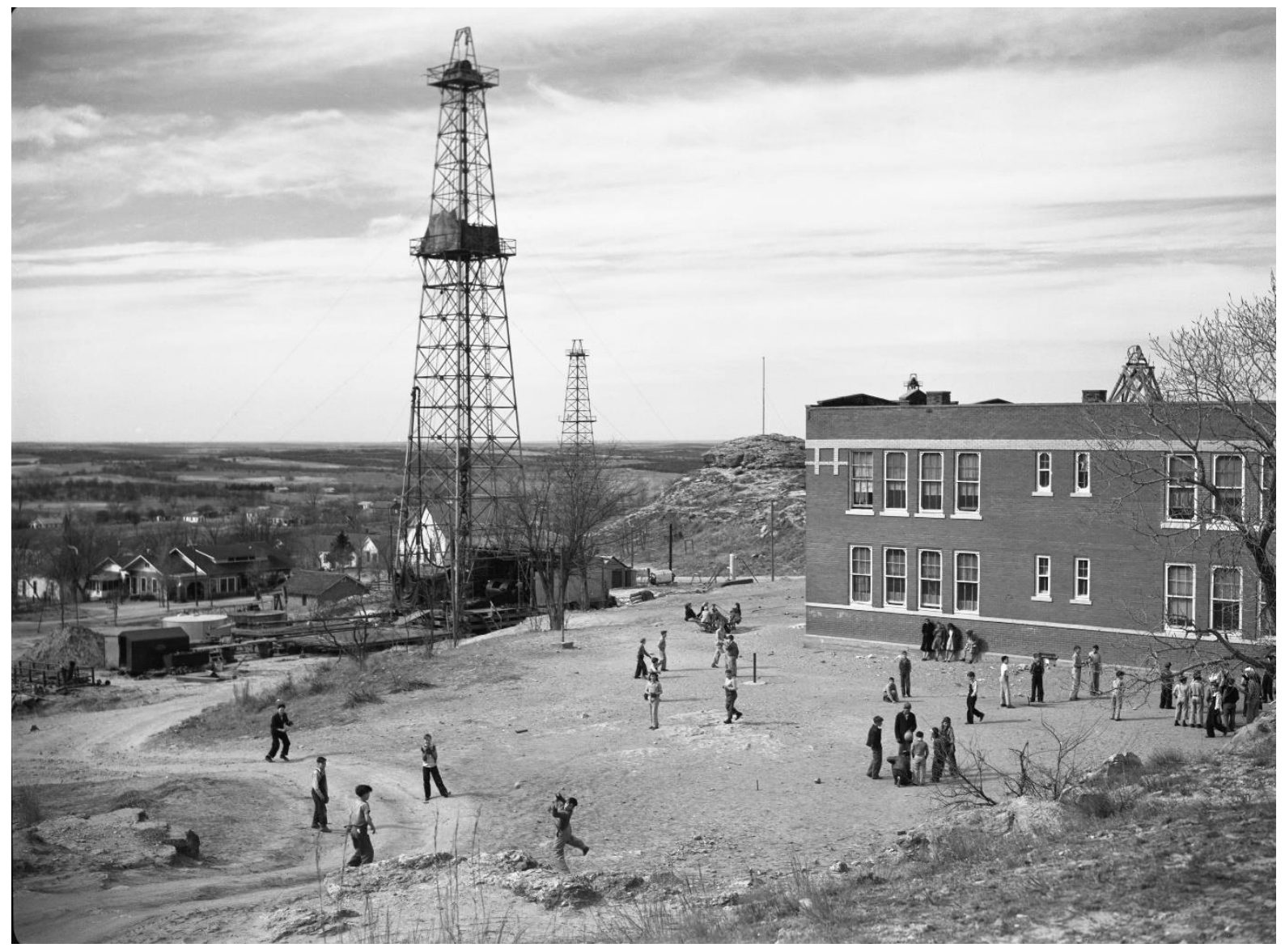

Image 11 (Corsini, H. 1946. Cement, Oklahoma. Standard Oil of New Jersey Collection, \#33311. Photographic Archives, Ekstrom Library, University of Louisville.)

Image 11 is a photo Corsini shot in Cement, OK where, as referenced in his letter, the oil derricks had been drilled extremely close to the school building. Other photos of Cement showed wells dug in the center of main street and extremely close to residential areas. 
Image 11 was excluded from any publication for Standard Oil or the oil industry, most likely for the reasons Corsini mentioned. From this example, we know that the project's photographers had the autonomy to shoot whatever they found to be interesting in the field. The photographs would then go through a selection and curation process before any type of further distribution to media outlets or exhibits. However, these counter points to SONJ's stated position of the oil industry's efficiency and conservation practices remain in the archive. We also know that the photographers photographed anything that was related to oil, not specifically Standard Oil New Jersey. Corsini mentioned that Carter Oil (a SONJ affiliate producer) only had two wells in the area and they were not producing. This is evidence of an interrelated and interconnected vision that SONJ had of the whole industry, not just a desire to highlight affiliated companies. This is potentially why Humble Oil was not mentioned in the Tomball Coronet piece.

Corsini Correspondence 2: May 9, 1946

“... Eddie is staying here for the moment and canvassing towns in the area for his picture story on oil towns. We are having a tough time picking a town that oil built and that is still a town today. First we thought Shawnee would do but it isn't anything today. Seminole is a bad advertisement for oil and Tulsa is too much an exception to be representative. So he hunts towns while I climb derricks and shoot drillers." (Corisni Correspondence 1946. The Roy Stryker Papers. Photographic Archives, Ekstrom Library, University of Louisville.)

Oil towns that experienced a boom had the reputation of being chaotic and violent. Each newly discovered oil field spawned a mad rush to produce as much oil as possible from each individual lease. There was little to restrain producers from getting as many leases as possible and little to incentivize private property owners from selling those leases. Towns had rapid population increases. Regional economies experienced dramatic inflation (Olien 
and Hinton, 1982). From a 'conservation' stand point, booms prompted unplanned and uncontrolled production that depleted the gas or water pressure needed to push the oil above ground and left oil trapped beneath the surface. Additionally, a rushed extraction took precedence over finding the ability to store or transport oil, leaving oil to evaporate in nearby dug holes (Zimmerman 1957). Beyond conservation, and more concerning to the industry was that booms lead to overproduction and thus market volatility and a collapse in prices (Huber 2011). After an oil boom, a town gradually declined in population and outside investment stopped. The change was often slower than what the term 'bust' might imply. A smaller oil operation might remain. Other times, the town wase left completely deserted. It was difficult to determine which towns would survive and which would not (Olien and Hinton 1982).

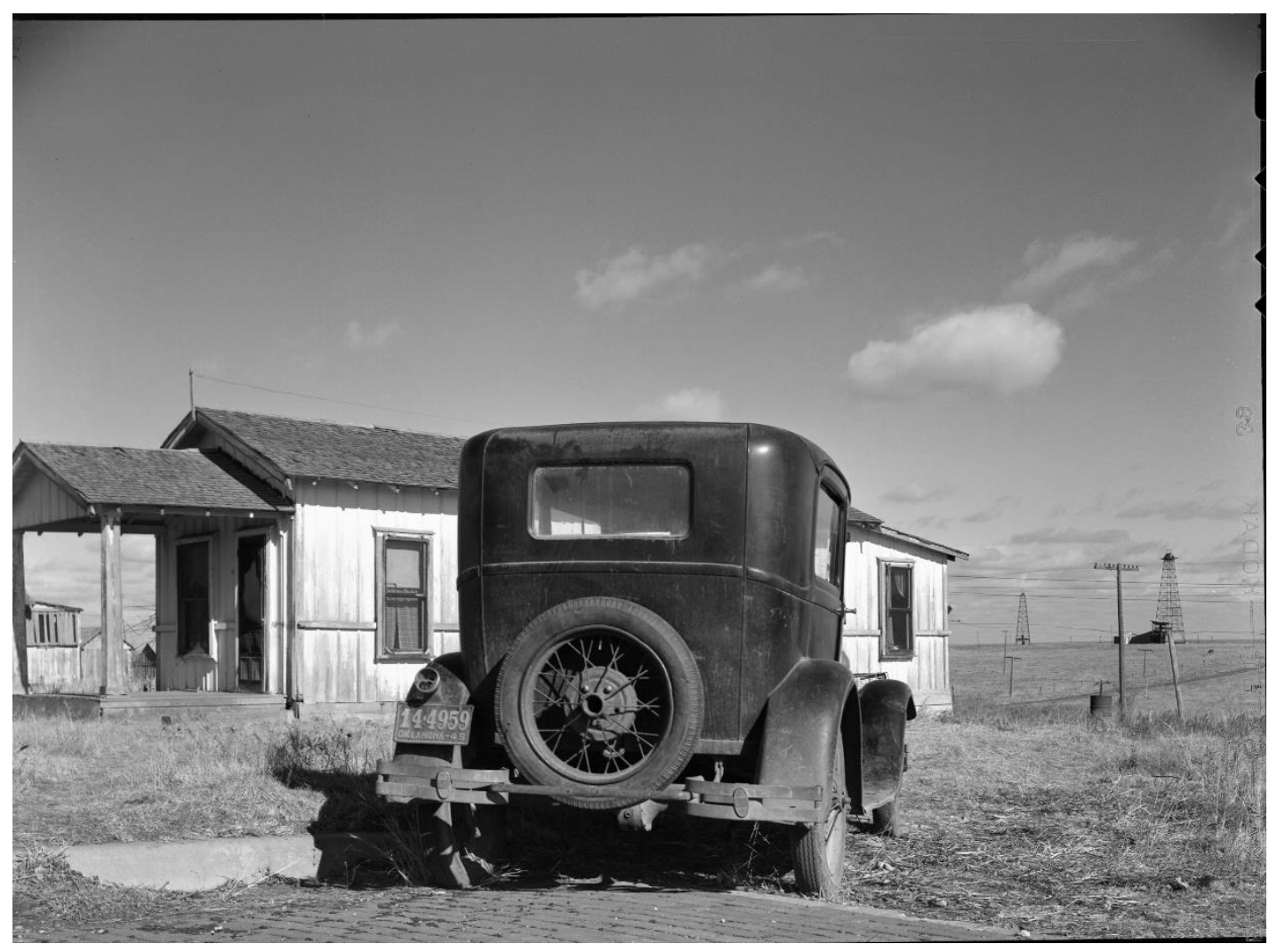


Image 12 (Corsini, H. 1946. Standard Oil of New Jersey Collection no 31796, Photographic Archives, Ekstrom Library, University of Louisville.)

The photograph above (Image 12) shows the ghost town, former oil town, Shidler, OK. Corsini liked Shidler and small towns in Oklahoma because the vacant rundown buildings and deserted streets made for intriguing photographs. The few people in these towns were most likely oil workers who drove in and checked the pumps from time to time. Corsini noticed that most all the oil workers drove this one type of car, 'the fliver', which was durable and could get through muddy conditions.

Corsini Correspondence 3: May 21, 1946

We are in a town called Cushing, the motto of which is "Keep Cushing". Obviously those who thought this up meant it as some sort of pun, but I'm taking it literally and am hoping that they keep it and with all my thanks. This town was represented to me as a town that an oil boom had not ruined, had not expanded its population from 800 to 25,000 overnight only to lose the increase at the diminishing of the oil flow and once again revert to its former nothingness. ... It has (the town has) a lot, but it has not got one thing, and that missing thing is $C-H-A-R-M$. I've been banging my head and shutter against this town, I'm afraid, to little avail. ... At one time twelve refineries were located in or near the city. At one time seven hundred tanks held the overflow of crude in tank farms spotted around the countryside. A network of pipelines still laces the area. ... No matter how I feel about it Cushing is sort of remarkable. (Corisni Correspondence 1946. The Roy Stryker Papers. Photographic Archive, Ekstrom Library, University of Louisville.)

Corsini sent his observations and research on Cushing to Roy Stryker in May 1946.

He had been searching for a representative oil town since February. Cushing, Oklahoma was founded in 1892 and remained a small farming town until it boomed in 1912 with the discovery of oil (Corsini Correspondence, 1946). Unlike most boom towns, Cushing survived and became a regional hub for the smaller farms towns nearby. At the time of Corsini's research, the town's the population was around 8,000 people. Corsini was surprised to find the types of stores that usually only existed in cities with larger populations. There were new roads, a new library, multiple movie theaters, multiple jewelry stores and a 
small airport with four small private airplanes. Corisini did investigate how Cushing afforded updated infrastructure, however he disclosed his assumption to Stryker - that these amenities are supported by a few wealthy residents who made money from oil and had since stayed in Cushing (1946). Cushing has recently been of national interest because the XL pipeline is planned to go through the city.

The photographs that Corsini took of Cushing became some of the most widely distributed photos in the SONJ collection and some of the most famous shots Harold Corsini took during his career. Ironically, Corsini had initially disliked the town and thought it to be bland. These correspondence letters by Corsini showed Cushing as an exception to most oil town geographies. Despite this, Cushing was added to a small list of representative oil towns used by the SONJ project: Cut Bank, Montana; Tomball, Texas; and now Cushing, Oklahoma - Cushing was the largest and most recently updated of the three.
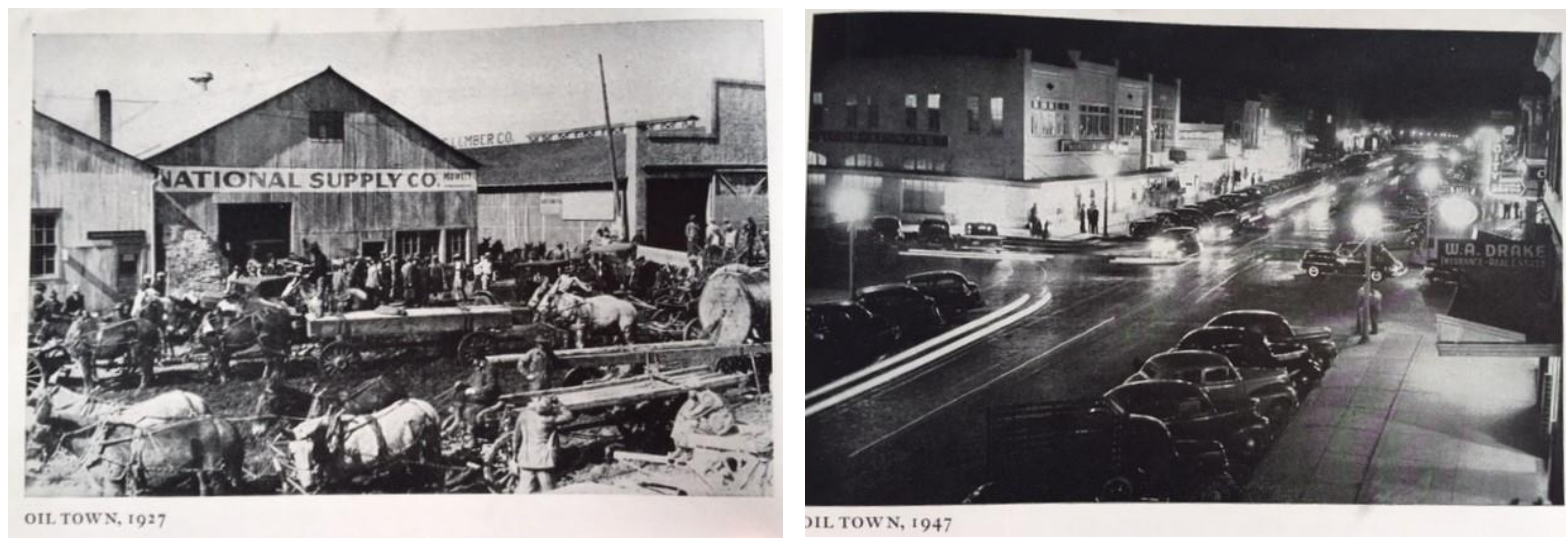

Image 13. (left) Oil Town 1927 and Image 14. (right) Oil Town 1947 (as found in SONJ's World for the World. Schackne and Drake, 1950; 30-31)

The Standard Oil New Jersey collection used photographs of Cushing at times where it wished to display a stable and modern example of how the oil industry invested in and benefited rural America. In the book, Oil for the World (published by Standard Oil New 
Jersey) one of Corsini's photos of Cushing in 1946 was placed opposing an image of a crowded oil town in 1927 with a dirt road and horse drawn carts (Schackne and Drake 1950; 30-31). The book labeled the date incorrectly as 1947. Neither photo was cited or given a location (Image 13 and 14). The surrounding text is a chapter on the history and advancement of exploration and drilling techniques and does not mention conditions of oil towns, historic or present (1950; 23-38). While the lack of context is confusing, it was perhaps purposeful. The juxtaposition communicated that within a span twenty years, small oil towns gained a modern, automobile centric infrastructure.

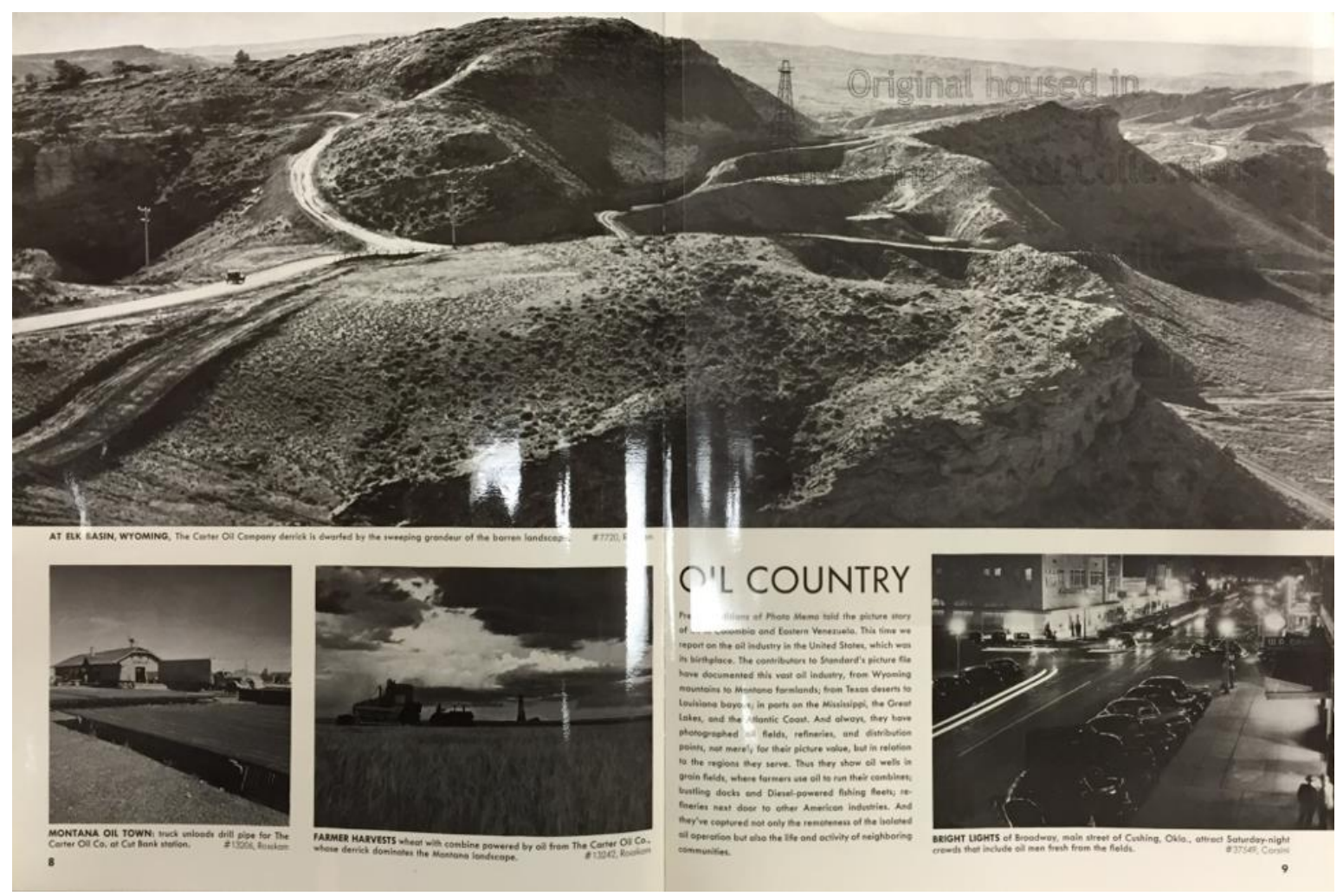

Image 15 Photo Memo No 4 Oil Country - Previous editions of 'Photo Memo' told the picture story of oil in Colombia and East Venezuela. This time we report on the oil industry in the United States, which was its birth place. The contributors to Standard's picture file have documented this vast oil industry, from Wyoming mountains to Montanan farmlands, from Texas deserts to Louisiana bayous, in parts of the Mississippi, the great Lakes, and the Atlantic coast. And always, they have photographed oil fields, refineries, and distribution points, not merely for their 
picture value, but in relation to the regions they serve. Thus they show oil wells in grain fields, where farmers use oil to run their combines; bustling docks and Dieselpowered fishing fleets, refineries next door to other American industries. And they've captured not only the remoteness of the isolated oil operation but also the life and activity of neighboring communities. ((Photo Memo No 4. August 1947. Special Collections Ekstrom Library; University of Louisville. p 8-9)

The Photo Memo (Image 15) titled 'Oil Country', displayed the same night scene of Cushing, OK used in Oil for the World alongside three other photos - rural scenes with oil derricks, one in Elk Basin, Wyoming and two in Cut Bank, Montana (1947). Cut Bank was again referenced as a 'Montana Oil Town'. The association of oil with farming wheat was highlighted with a picture of a tracker next to an oil derrick. Interestingly, the affiliate company that operatess in both Montana and Wyoming, Carter Oil Co, was referenced. Carter was not named in the 1945 Photo Memo No 1 on Cut Bank. A change in priority to talk about specific companies rather than the oil industry in general had been made in the previous two years. It is also interesting that Cut Bank and Elk Basin's own town centers were not used to conceptualizes 'oil country'. They were juxtaposed to a Cushing downtown that was more urbanized and modern looking. Originally, Corsini's caption of the Cushing photo in the archive file was flat and journalistic, "Broadway, main street of Cushing, at night" (Corsini, H. 1946; \#37549). The Photo Memo No 4 adds some flare, "Bright Lights of Broadway, main street of Cushing, Okla., attract Saturday night crowds that include oil men fresh from the fields" bold text in original (1947). This edit is evidence of a produced space. The latter caption was not only more lively, it also created an imagined geography that was not conveyed in the original. Juxtaposed to the rural oil field scenes, SONJ constructed a chain of practices where the oil town and oil field harmoniously existed separately in a modern, planned and controlled, mutually beneficial relationship. Additionally, the text for 
'Oil Country' that accompanied the photos for this piece (Image 15) was uncharacteristically grandiose and self-reflective compared to most Photo Memo texts. It referenced all of America as the birthplace of oil - not just a few oil producing sites. It discursively historicized the relatively young (at the time) oil industry as a longtime contributor to the country's development and integrated its operation seamlessly into a geography called 'oil country'. Created was a specific geographic imaginary of rural America where oil was in the background, readily available and in service to "neighboring communities". The same production happened in Tomball with the Coronet article (1946) and with Cut Bank (1945). However, Corsini's coorespondence show that this was a fabricated ordering of geographic information. The modern oil town that benefited from its oil history, in the ways SONJ suggested, is an exception. Further, a glaring hole in the 'oil country' geography, in all the examples of oil towns and their outskirts, was an image of the oil workers camp. Image 16 is a Carter Oil camp in Elk Basin, Wyoming. Photographer Rosskam called them 'trailer camps' (1944; \#12180). The structures were temporary. They differed drastically from traditional small town store fronts in oil town centers like Cushing, or a nostalgic porch like that in Tomball. The Coronet piece mentioned that their work camp invested in nice new houses and parks for Tomball. These in Wyoming were built for the short term and were most likely not an example of the Americana culture with which SONJ wished to be associate. 


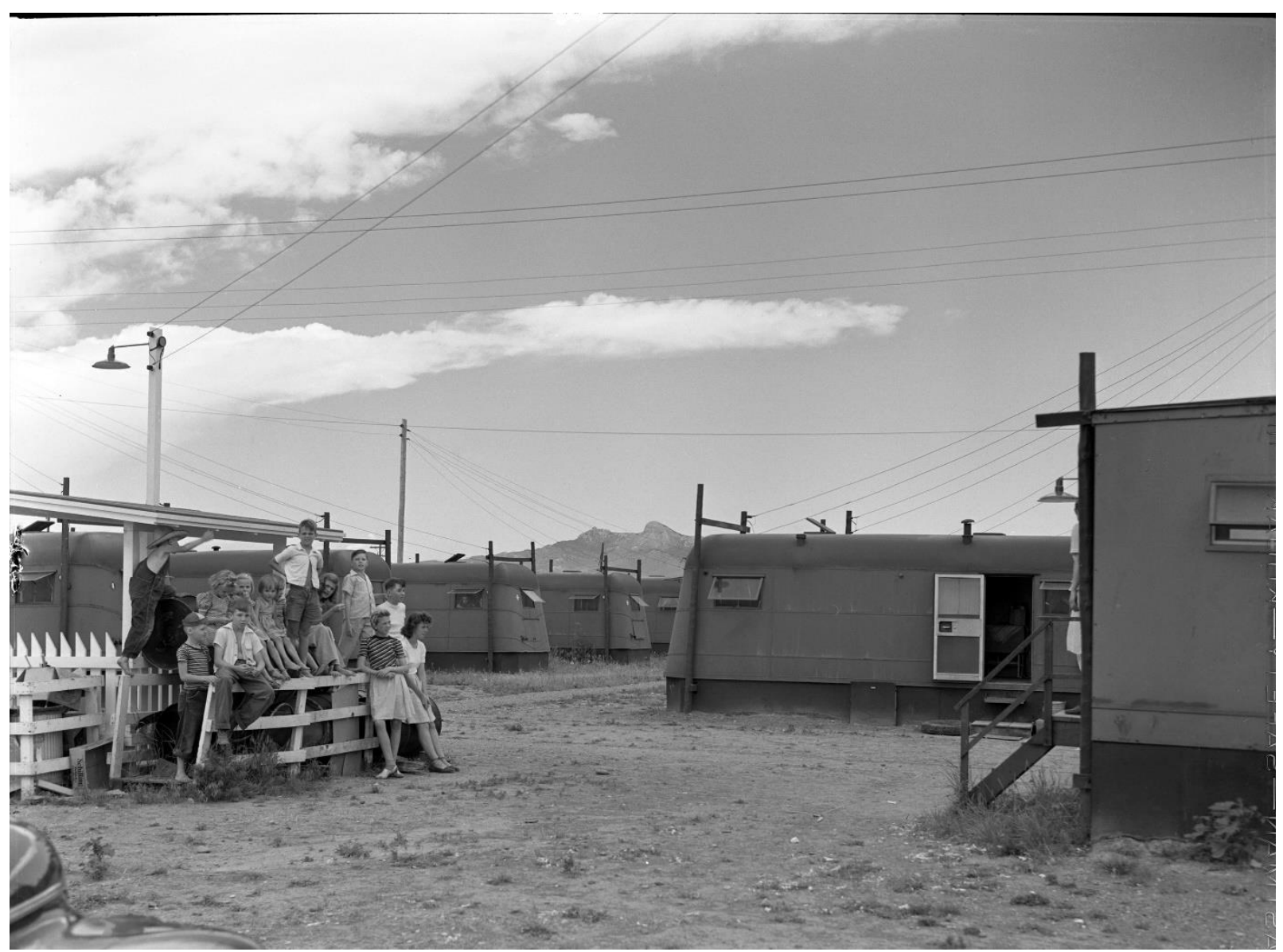

Image 16 (Rosskam, \#12180.used with permission from SONJ Collection, Special Collections, Ekstrom Library, University of Louisville.)

In the Photo Memo piece on 'oil country' (Image 15) there are three visions of everyday oil geography in the U.S. I am calling these adjacency pairs: 1) oil derricks and farmer's grain fields, 2) oil transportation ports and fishing fleets, and 3) refineries and other American industries. It does not take an expert in the production of oil to know that the same oil that the farmer used to fuel their tractor was most likely not extracted from a well in their own field. The diesel fuel that a fishing boat used was just as likely to have been pumped off a tanker at another port. The logic of the three adjacency pairs implied a direct producer to user relationship. The liquid materiality of oil makes it near impossible to track where oil was originally extracted or even where it was refined (Mitchell 2011). Huber wrote about the 
absurdity of the post 9-11 phenomenon of filling stations advertising "non-terror" oil. There would be no way for a single filling station to know whether oil came from the Middle East or from Canada (Huber 2012). These adjacency pairs were a way for SONJ to insert itself into an already familiar geographic imaginary. The reader was encouraged to view oil as calm, stable, and dependable because of its omnipresence when in fact oil could be unstable, chaotic, and unplanned. In the case of an oil town, oil can leave communities desolate and unaccompanied.

Implications

The repeated association of the oil industry with farming increased in the following decades with the wider use of petroleum based products in farming practices and the industrialization of agriculture (Cable 2012; Mitchell 2011). Similarly, the scopic regime of the Americana was later employed in advertising to show how American consumers used a variety of petroleum products besides gasoline, like plastics and lubricants, in everyday life (Huber 2012). The texts provided in this chapter are good references for how these advertising practices came about. Below are photos showing a farmer using petroleum based insecticide (Image 17) and a boy pretending to oil his toy car (Image 18). 

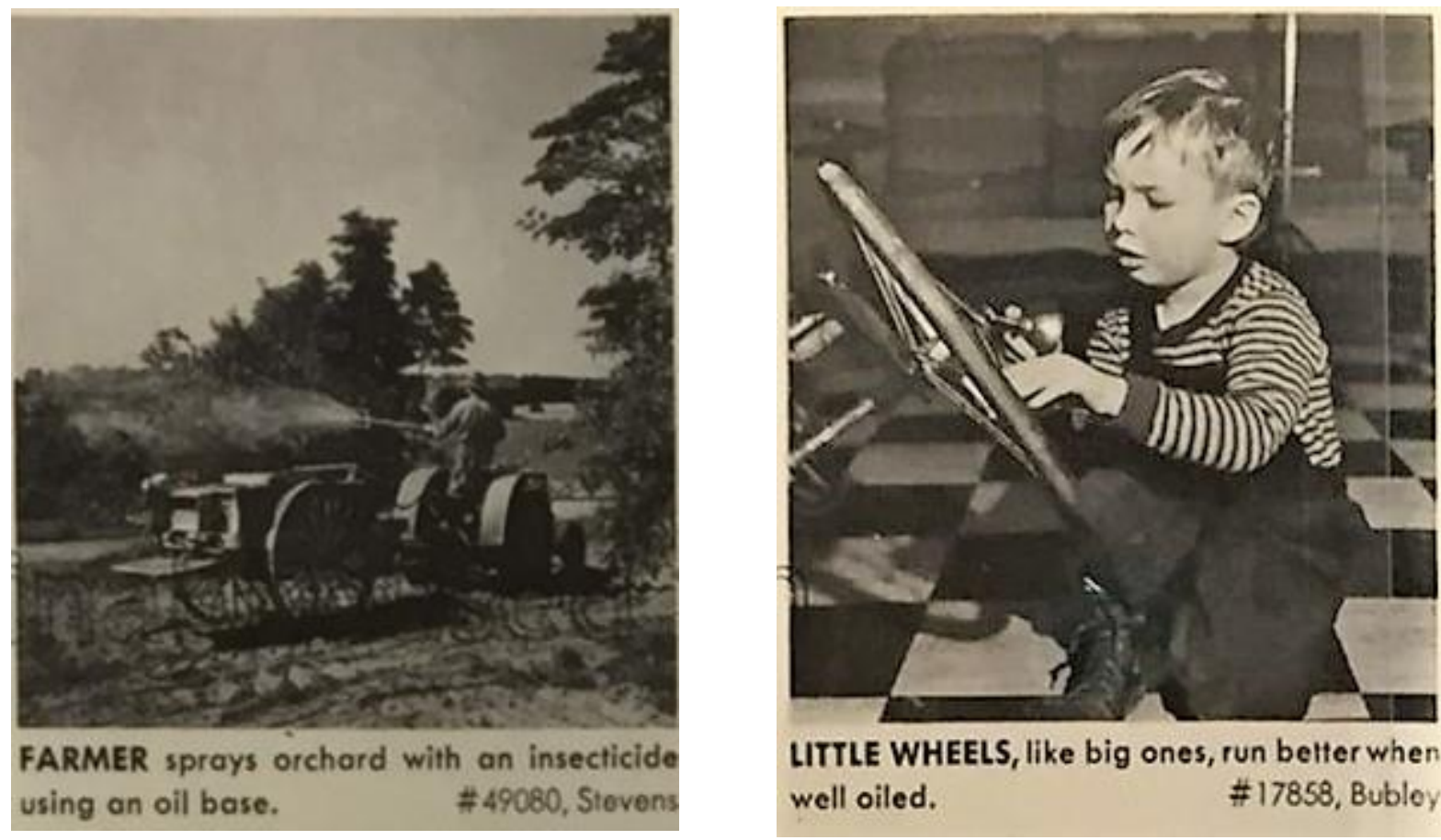

LITTLE WHEELS, like big ones, run better when well oiled. \#17858, Bubley

Image 17 and Image 18 (both photos found in Photo Memo No 5. 1948. Schinas Collection, Special Collection, Ekstrom Library, University of Louisville. page 14)

Beyond the establishment of promotional practices, this chapter argues that the production of space was a primary factor in a changed understanding of the oil industry and of oil's role in post WWII America. The postwar years were a time of transition for SONJ in the sense that it would increasingly find the majority of its oil supply abroad, first Venezuela and later Saudi Arabia. The SONJ photo file showed that the company was clearly still invested in presenting itself as an American company. The geographic imaginary of oil towns and 'oil country' allowed for the industry to be thought of as one in service to America and not as an industry that exploited the country's natural resources. In Tomball, oil's financial wealth would not corrupt American working class values. In Cut Bank, a 'marvelously compact refinery' would not change a homesteader culture. Cushing enjoyed all the benefits of small scale urbanization. I argue that SONJ still needed to address public 
concerns that the industry was taking advantage of American citizens, not only in relation to the scandal with IG Farben, but also concerns around exploitation of rural extraction sites. The texts provided in this chapter showed how in a time of transition and crisis SONJ discursively historicized itself as American and socially produced a space where it was in service to American small towns. While it seems contradictory to focus on domestic production sites while foreign oil was gaining more importance, this chapter's approach to the production of space illuminates how the oil industry navigated these contradictions. Following Lefebvre (1991), the production of space has the ability to generate or constitute the discourse that governs American oil consumers in a negotiation between things that are seemingly contradicting, i.e.: the oil industry was exploitive and the oil industry was accountable to small towns; Standard Oil New Jersey was a multinational company operating on the global market and Standard Oil New Jersey was American. 


\section{CHAPTER V}

\section{THE SONJ PHOTO MEMO AND CONTRADICTIONS IN THE POST WWII OIL}

\section{INDUSTRY}

This chapter focuses on the chain of practices by which geographic information was gathered and geographic facts were ordered to construct a particular geographic imaginary of oil. 'Geographic imaginary' as defined by Schwartz and Ryan, is “the mechanism by which people come to know the world and situate themselves in space and time" $(2003 ; 6)$. The SONJ photo file constructed an imaginary of global oil production across multiple countries with every segment of the industry represented. The reach and scale of the file was an attempt at complexity and completeness. The actual result was a gross simplification of detail and a flattening of politically charged moments in the production of oil. Two significant moments in oil production, 1) conservation and 2) Venezuela, show the ordering of geographic information when photos were disseminated to public media outlets. Despite the tags of 'journalistic objectivity' or 'photographic realism' that the archive operated under, the moment of dissemination required a choice by SONJ and was not random. I argue that this preferential ordering of content is a window into how an oil corporation managed discursive texts meant to orientate the American public toward a specific culture of petroleum use. 
It is a rare case where both conservation and abundance were shown side by side; where both domestic (U.S.) and foreign (in this case Venezuelan) production was visualized in the same text. These existing categories appear to be contradictions. However, under the assumption of photographic objectivity, the association between contradicting categories become normalized. Oil literature has described the postwar years to be times of expansion but also volitivity as the oil industry moved towards both integration and fragmentation (Huber, 2012; Labban, 2010; Yergin, 1991, Larson, Knowlton, and Poople 1971). The casual presentation of known contradictions helped to perpetuate a narrative of control and restraint in the context of intense transition. These tropes were important in negotiating questions of domestic vs. foreign oil and questions of conservation vs. abundance of a nonrenewable resource. Produced was a complex set of discourses around nationalism and natural resource management. Associations that seemed to be less in conflict and more normal helped acclimate American oil consumers to times of expansion and growth.

The chapter first introduces the genre of the Photo Memo as a publication that was intended to show the diversity and scale of the SONJ photographic file. These memos were similar to, and at times, mimicked traditional magazine stories in how they formatted visual content and captions, paired together with text. Second, I contextualize two moments that were both central themes in the whole photograph collection and were also displayed in multiple Photo Memo publications: 1) conservation, 2) foreign oil production with Venezuela as an example. Much has already been written about these topics and how they were perceived to be in conflict at the time (Yergin, 1991; Zimmerman, 1957). My goal is to add a reference of just how the SONJ public relations department used these moments to produce a taken for granted association and thus a normalized culture of petroleum use in the US. 
And lastly, I conclude the chapter with an intertextual discussion of how these two moments worked together in the production of discourse.

\section{1) 'Patterns of Oil': A Photo Memo Introduction}

The Standard Oil New Jersey Photograph Collection was a unique project in the history of oil media in terms of both its volume of texts and of its diversity of content. This diversity was present at all stages of the project. From the conception, production, dissemination, consumption, and preservation of around 80,000 photographs, the project's goal was to document all of what oil influenced. This diversity was clearly shown in the Photo Memo. There were six total Photo Memo publications, the first released October 1945, the last January 1949. All followed a similar style and format - glossy booklets with sixteen pages and around 40 to 50 photos total. Each photo had a caption and cited photographer, arranged in various size dimensions, curated and grouped together around topical themes. The Photo Memo acted as a general sampling and summation of the types of photos that SONJ had in their collection. It was distributed to various media outlets with the expressed invitation to either use any of the photos or contact the public relations department for free access to similar photos. These memos were a juxtapositioning of written text and visuals, ripe for discursive analysis. The Photo Memo had the clear purpose to display the quality of photographs and the variety of content available in the archive. However, these curated themes can be viewed as moments of authorial organization in the production of a specific orientation towards the oil industry. The themes chosen in the memo were often simple and broad: 'Drilling', ‘Colombia', 'Faces', 'Oiltown', 'Going to Work'. This curation was an organizational level above the photographer's lens. The tacit photograph was active in the 
taxonomic ordering of the oil industry as some themes were given center focus and some content fell unattended.
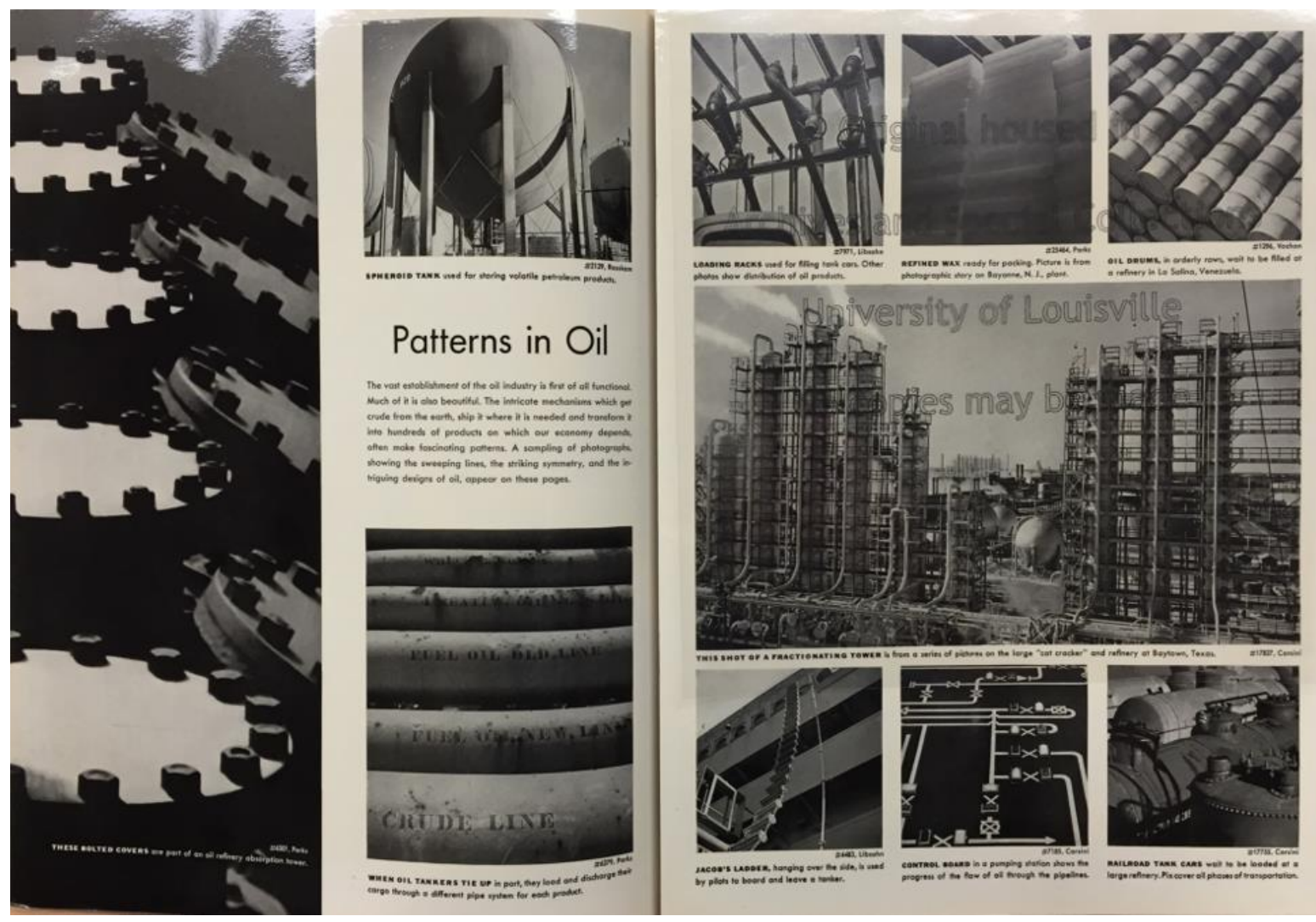

Image 19 "Patterns in Oil -The vast establishment of the oil industry is first of all functional. Much of it also beautiful. The intricate mechanisms which get crude from the earth, ship it where it is needed and transform it into hundreds of products on which our economy depends, often make fascinating patterns. A sampling of photographs, showing the sweeping lines, the striking symmetry, and intriguing designs of oil, appear on these pages." (Photo Memo No2. June 1946. Special Collection Ekstrom Library; University of Louisville. Page 6-7)

"Patterns in Oil" (Image 19) was a two-page layout using a format common to the

Photo Memo genre - a single theme per two pages with a paragraph text accompanied by photographs from multiple photographers and locations. The "Patterns in Oil" text argued that while the oil industry's infrastructure was first 'functional', it could also be 'beautiful'. 
This statement reads as absurd to a post Exxon Valdez interpretation of oil and its aesthetics. Since the 1989 spill and more recent the unsightly 2010 Deepwater Horizon spill, the oil industry has been preferred to exist unseen. But in the 1940's, the oil industry was ready to shed a perception of chaos and common associations with irresponsible extraction techniques. SONJ strategy for accomplishing this was to show to the public detailed and up close up profiles of industry practices. Further, it is important to note that the public relations department at Standard Oil New Jersey were neither 'oilmen' nor engineers who were used to the everyday sights of refineries, machine shops and pipelines. From their offices in Rockefeller Plaza in New York, the public relations department was fascinated with the terse materiality of their own company's vast infrastructure. Freyermuth's description of the 'Architecture of Oil' exhibit (chapter 3), was a good example of the institutional divide (1946). The Photo Memo's contextualization of oil as planned, designed and patterned countered a discourse of a haphazard and greedy industry. It showed photos from multiple sites: loading racks that fill tank cars; refined wax from a plant in Bayonne, New Jersey; oil drums from La Salina, Venezuela; a fractioning tower at a refinery in Baytown, Texas; a pipe system for oil tankers; a ladder hanging from the side of a tanker; a control board at the pumping station; and railroad tank cars. In sum, these scenes served as a particular visual mapping of the integrated oil industry of the 1940's; all segments of the industry were represented - production, refining, transportation, monitoring and product manufacturing. Further, this juxtapositioning signaled the multiple scales of oil production for the reader to consider simultaneously. The close-up of metal drums and wax blocks were presented next to the manmade landscape of the refinery, which was next to photos that reference a general method of transit across vast distances. Some photos were not cited with a location and were 
meant to represent a general scene of oil that could be anywhere. And other photos of domestic locations- New Jersey and Texas, were placed next to a scene abroad - Venezuela.

Two productive moments are noted in this themed layout Patterns in Oil that are consistently found in the SONJ project. First is the deployment of the photograph (and the whole photographic archive) as a device for mapping out, monitoring, and organizing the oil industry. Second is the production of a complex set of discourses around control and expansion, stability, and efficiency, that would characterize the oil industry post WWII. The following sections examine these discourses.

\section{2) Conservation and Venezuela in the Photo Memo}

In this section, I give a detailed contextualization of first conservation and then Venezuela. I use secondary materials to illuminate the political nature of both moments. I compare these contextualizations with the casual and seemingly neutral SONJ representations of conservation and Venezuela. The contradictions between politically complex moments and simplistic representations are evidence of discourse around control and stability, technical progress and nationalism.

Conservation in the Photo Memo

'Conservation', as it pertained to the oil industry, was a controversial and problematic term by the 1940's when the SONJ collection was created. In recent decades, conservation has been delegated to the consumer. And politically, the idea of conserving oil products has not had much traction outside of President Obama encouraging the proper inflation of tires to 
conserve gasoline on road trips during the 2012 campaign. The logic of the market has produced a narrative claiming that the industry will only produce at the level of consumer demand and thus has passed on responsibility to the user (Huber 2011). But this has not always been a natural assumption in the market. Prior to this discourse, the industry's management of oil as a non-renewable resource was under scrutiny. The stated purpose of conservation in the Photo Memo No 4 (Image 20), 'to eliminate waste', should be read as a drastic simplification of a complex and political issue. To properly contextualize the archive and Standard Oil New Jersey's discussion on conservation I summarize some of the issues around 'conservation' at the time. I use two types of sources. First, I use books and reports written around the time of the SONJ photo collection. Primarily I use a petroleum monograph volume funded by the American Petroleum Institute (API), Conservation in the Production of Petroleum: A study of Industrial Control (Zimmerman 1957). Second, I use contemporary critiques by energy geographers who have discussed the social production of 'scarcity' and 'abundance' in the market as it relates (or does not relate) to oil supply and oil price. Then I show how SONJ used a the restrictive framing of the conservation problem with a neutral and objective narrative and in doing so produced a discourse where the oil industry was viewed as a technical innovator and an integrated team player in the modern economy. 

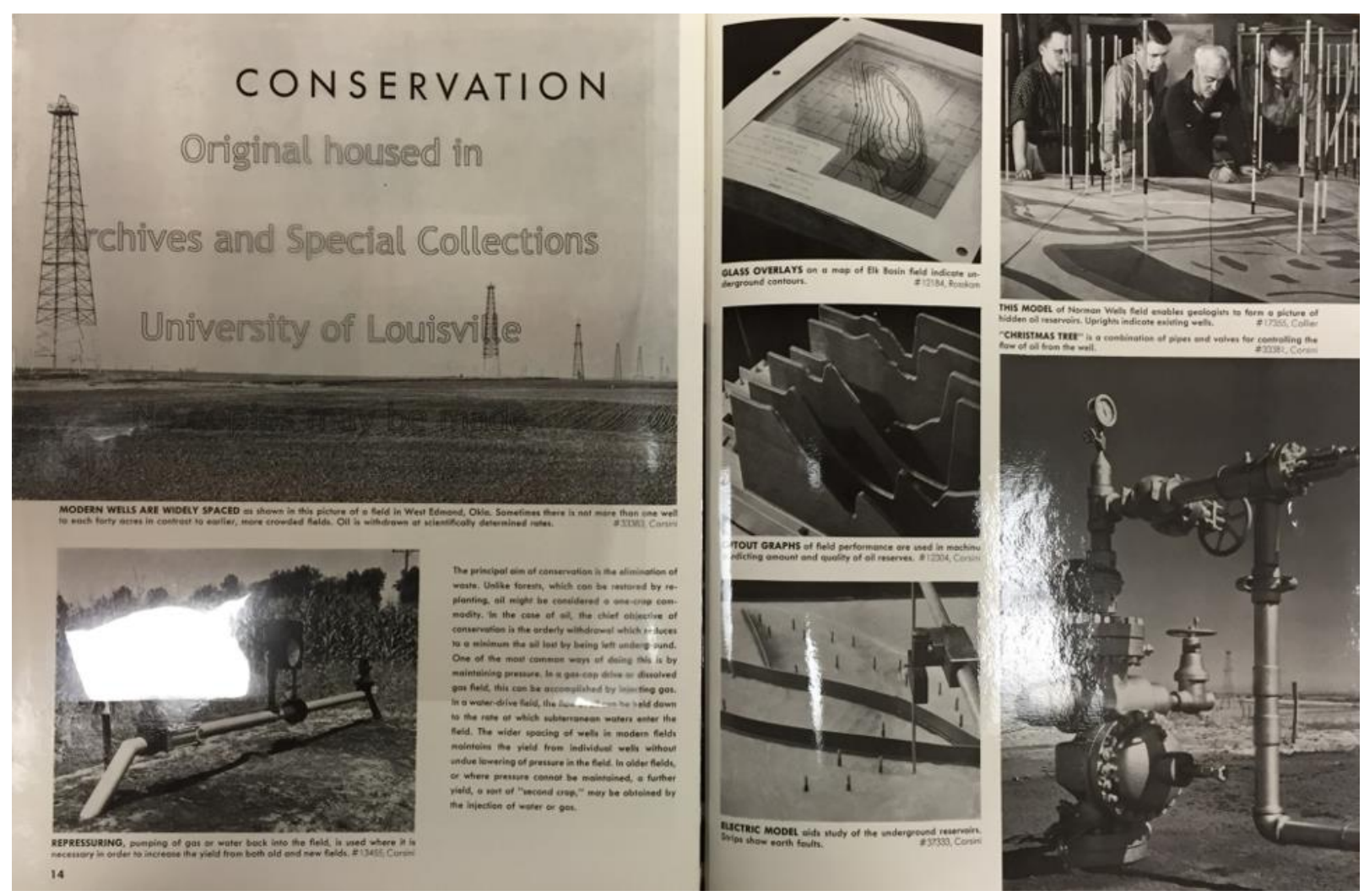

Image 20 - Photo Memo No 4 -Conservation -The principle aim of conservation is the elimination of waste. Unlike forests, which can be restored by replanting, oil might be considered a one-crop commodity. In the case of oil, the chief objective of conservation is the orderly withdrawal which reduces to a minimum the oil lost by being left underground. One of the most common ways of doing this is by maintaining pressure. In a gas-cap drive or dissolved gas field, this can be accomplished by injecting gas. In a water-drive field, the flow of oil can be held down to a rate at which subterranean waters enter the field. The wider spacing of wells in modern fields maintains the yield from individual wells without undue lowering of pressure in the field. In older fields, or where pressure cannot be maintained, a further yield, a sort of 'second crop' may be obtained by the injection of water or gas. (Photo Memo No 4. 1947; pages 14-15. Special Collection Ekstrom Library; University of Louisville.)

Regulation of the oil industry in the US prior to the 1930's was limited to the protection of personal and property rights such as appraisals on safe drilling operations and the proper sealing of wells that were no longer in use. The elimination of waste, or 'conservation', was treated with indifference. Prompted by 'the rule of capture', common 
practice was to pump as much oil as you could as fast you could, before a neighboring property owner's well pumped that oil (Zimmerman 1957; 91-100). An 1889 Pennsylvania Supreme Court reasoned that the rule of capture would allow for more oil production and thus cheaper oil prices for consumers. However, this encouraged a landscape full of oil wells stacked next to each other over an oil field and a quick depletion of field pressure. In Standard Oil New Jersey's own publication, Oil for the World, the 'early oil field' with derricks built close together was compared to the 'modern oil field' where wells are orderly and spaced out. The photo used (Image 22), was the same used in the Photo Memo No 4 (Image 20) to display good conservation techniques.

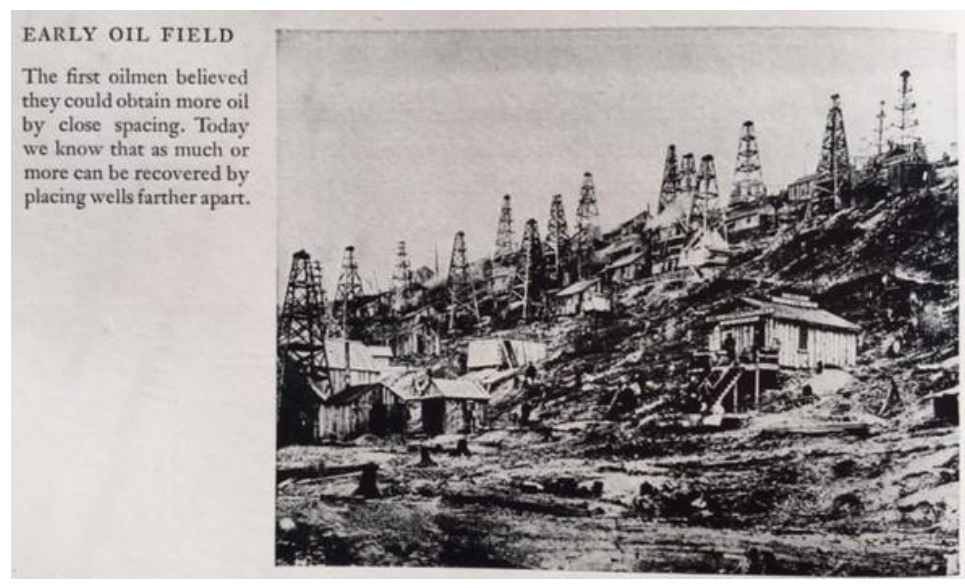

(Image 21 (top) Early Oil Field and Image 22 (bottom) Modern Field. found in Schacke and Drake, 1950 World for the World: 52)

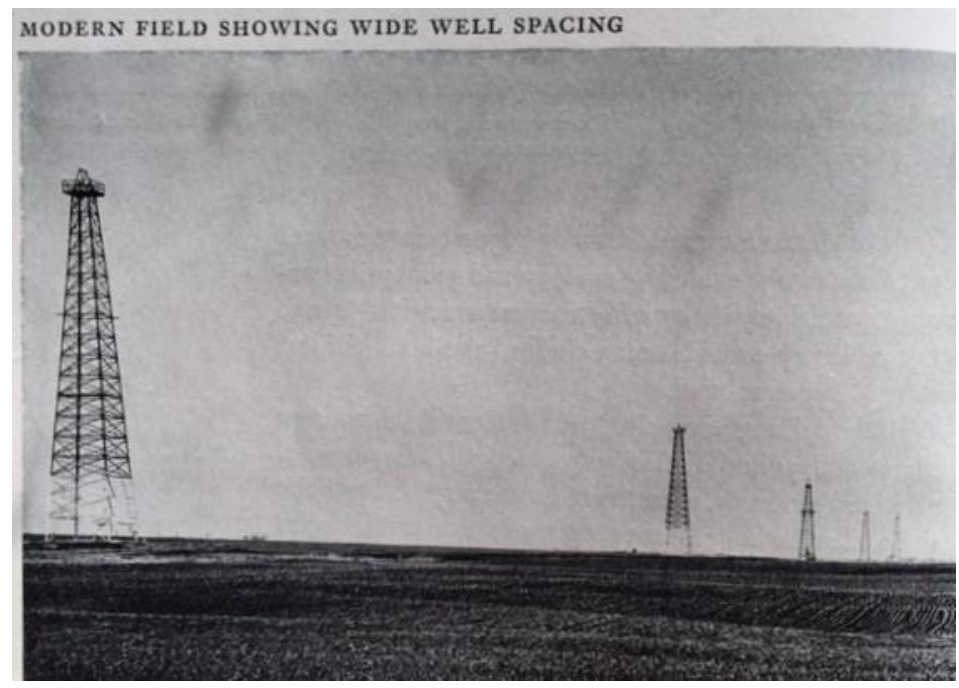


As oil increasingly became an important economic and strategic asset, waste was viewed with intolerance and production became increasingly regulated and supply of oil reserves became increasingly monitored (Zimmerman 1957). Waste should be understood as referring to two different things: 1) the oil that is left in an oilfield that is too expensive to recover relative to the price it could be sold. The Photo Memo No 4 gave a technical explanation of how this type of waste could be avoided with monitoring technology and responsible management and then made the case that SONJ had the capacity for such efficiency. Waste should also be understood as, 2) the overproduction of crude oil that exceeds the current market demand and thus, gluts the market and decreases oil prices. Zimmerman explains that while 'conservation' may have the stated intention of preventing the former type of waste (physical waste), this is at best an incidental effect of the "real aim" of preventing the latter (economic waste) and allowing bigger profits for the petroleum industry, especially for larger integrated companies $(1957 ; 3)$. In other words, the definition of 'conservation' by SONJ was subversively a defense of big oil and a regulated, stable oil market. The regulation of the amount of oil produced domestically was largely left to state regulatory agencies such the Railroad Commission of Texas and the Corporation Commission of Oklahoma and the negotiation between these agencies by The Interstate Oil Compact Commission. During an 'overproduction' crisis in the 1930's, the commission's regulation was enforced by the national guard of Texas who stood guard in the oil fields to prevent production (Huber 2011). This regulation and government intervention, benefited the companies who were already producing and integrated into the market - larger oil companies. 
Zimmerman's volume includes an interesting discussion on economic political theory at the time which was critical of big oil and petroleum production as a departure from free enterprise and market competition. Other books that critiqued petroleum conservation included: Oil: Stabilization or Conservation? A Case Study in the Organization of Industrial Control (Watkins, 1937), Rebirth of Monopoly, A Critical Analysis of Economic Conduct in the Petroleum Industry in the United States (Kemnitzer, 1938), Control of the Petroleum Industry by Major Oil Companies (Cook, 1941), A National Policy for the Oil Industry (Rostow, 1948), and Monopoly and Free Enterprise (Stocking and Watkins, 1951). These texts take a classical liberal economist argument against state interference in the market. Similarly, a noteworthy report was issued January 31, 1949, by representative for the National Oil Marketer Association, Paul Hadlick, to the Special Senate Committee to Study the Problems of Small Business that declared the conservation practices allowed the petroleum industry to act as a monopoly. It stated that the monopoly was bolstered by three institutions: the proration laws of oil-producing states, federal legislation, and large oil companies. (Zimmerman 1957; 18). Hadlick suggested that the monopoly be broken up by 1) discontinuing the limitation of production to market demand and the establishment of "true conservation", 2) prohibiting the Bureau of Mines from making forecasts on demand, 3) the investigation by Congress on the Interstate Oil Compact to determine constitutionality (of regulation), and 4) amending the Connally Hot Oil Act which prohibits the interstate movement of oil produced in violation of state proration laws (1949).

Zimmerman does not hesitate to call the structure of the petroleum business at the time an oligopoly - competition among few (1957). And despite his acknowledgment of conservation as controversial and inherently contradictory in the face of traditional capitalist 
principles, Zimmerman ends his volume with a defense of government interference and the adjustment of supply to demand that benefitted larger oil companies. He argues that traditional economic theorists like F.A. Hayek treat competition as a fetish, unrealistic in practice in a heterogenous reality of large scale production, large up-front investment, and large risk necessary in providing oil for the nation's economy. How Zimmerman presents this oligopolic structure as common sense should not be surprising considering his volume was funded by the American Petroleum Institute. What is interesting is his justification. Citing interviews with top executives in the oil industry (whom he does not name), Zimmerman believes that the oil industry is part of a changing world where big business accepts a role of servicing an interdependent economy where profits are no longer the primary concern $(1957 ; 20-23)$. Thus, oil production was a service and the oil industry was willing to work with governments and even with competitors to meet demand in a growing economy. The appraisal of big oil's role is presented as fresh and progressive by Zimmerman $(1957 ; 22)$. Determining whether this account of sacrificial, and unnamed, oil executives can be considered sincere is not the concern of my project. However both Zimmerman's narrative, along with the Photo Memo, introduce specific tropes that became useful in the volatile postwar oil market: control, restraint, management through technical innovation. Produced was a narrative that seamlessly integrates oil into the larger economy.

Venezuela in the Photo Memo

"If there had been no perfect illustration of what U.S. technical and capital resources could do for the world's underdeveloped areas, it would have been necessary to invent the Republic of Venezuela" (Fortune, 1949: 101). 


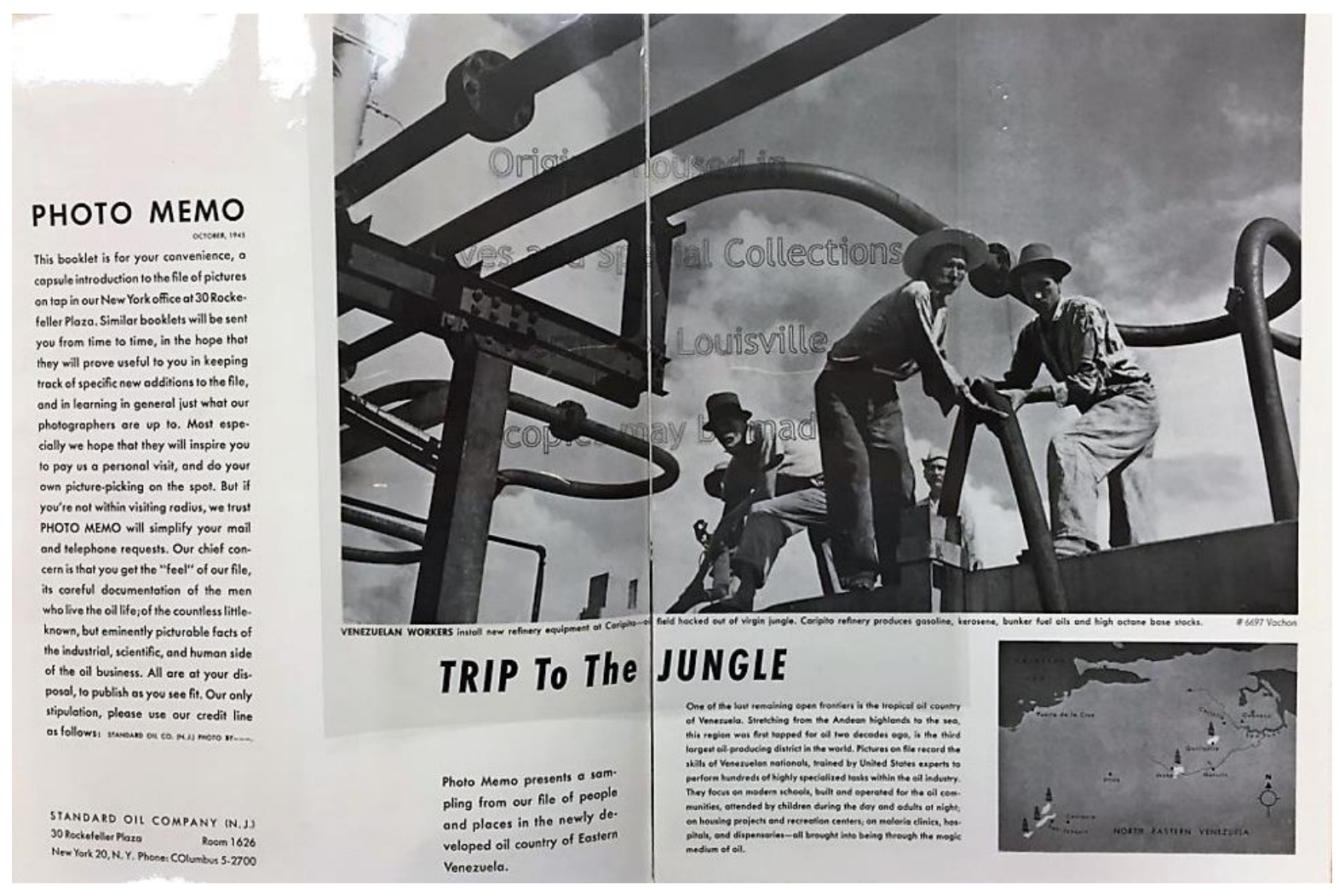

Image 23 - Trip to the Jungle - One of the last remaining open frontiers is the tropical oil country of Venezuela. Stretching from the Andean highlands to the sea, the region was first tapped for oil two decades ago, is the third largest oilproducing district in the world. Pictures on file record the skills of Venezuelan nationals, trained by United States experts to perform hundreds of highly specialized tasks within the oil industry. They focus on modern schools, built, and operated for the oil communities, attended by children during the day and adults at night; on housing projects and recreation centers; on malaria clinics, hospitals, and dispensaries - all brought into being through the magic of oil. (Photo Memo No 1. October 1945.Special Collections, Ekstrom Library; University of Louisville, p 2-3)

The first layout in the first Photo Memo publication in October 1945 was a piece on the oil production in Venezuela (Image 23). At the time, Venezuela was the world's leading oil exporter, and the largest oil producing company in Venezuela was Creole Petroleum Corporation, a SONJ affiliate. Creole was the parent company's largest volume producer world-wide. When Standard Oil New Jersey bought concession rights from Standard Oil Venezuela in 1929 to produce oil under Lake Maracaibo and then combined it with other 
affiliates to create Creole Petroleum, it became the single largest foreign investment of any American company at $\$ 135$ million dollars, said a TIME magazine article titled Venezuela: A Good Neighbor (1955). Venezuelan production became known as a linchpin in U.S. supply, specifically strategic to Allied reserves during WWII (Yergin, 1991). And while the SONJ Photo Memo No 1 mentioned Venezuela's importance in global oil production, the focus of the text was on the social investment the company had made in the country: the building of infrastructure, the providing of services and the training of a work force. And similar to the SONJ representation of conservation, I argue that this depiction of Venezuela was a restrictive frame on history and flattened out conflict and political nuance.

The next page of the memo (Image 24) showed a residence in a company built work camp with a caption, "Morning sun touches the outskirts of the Eastern Venezuelan town of Caripito. The houses, typical of many tropical dwellings, are often built with concrete walls for coolness and roofed with sheet iron to withstand heavy seasonal rains" (Photo Memo No. 1, 1945; 4). Following the common practice of photographic documentation, the memo was invested in displaying everyday life in Venezuela and in this case giving detail about common building materials. However, the text left out the fact that Caripito is a 'work camp' for oil company employees, even though the photographer Vachon documented such in his original caption found in the photo file archive (Vachon, 1944, \#6808). Instead, the memo's caption simply called Caripito a town. The previous page in the memo referenced the more vague 'oil communities'. Miguel Tinker Salas writes about the complex relations between the Venezuelan government, labor, Venezuelan society, and the foreign oil companies from the perspective of someone who grew up in Caripito (2009). Salas compares these work camps to the mining coal company towns in the US where the company provided for and 
controlled almost all aspects of life in the town - a closed micro economy. These camps were common place in Venezuela where oil was being produced. With a weak government apparatus, foreign oil supplemented services by providing infrastructure improvements like roads, sanitation, water, and electricity along with social services like schools, sports fields, community clubs and hospitals. While the company town model had a negative connotation the in U.S., the work camp was framed in Venezuela as 'progressive industrialism' and served to co-opt any oppositional voices about foreign oil. In fact, the improvement of work camp conditions was often argued for by labor unions in Venezuela (Salas 2009; 2-18). This comparison to a company town is one likely explanation for why the Photo Memo No 1 did not call Caripito a work camp.

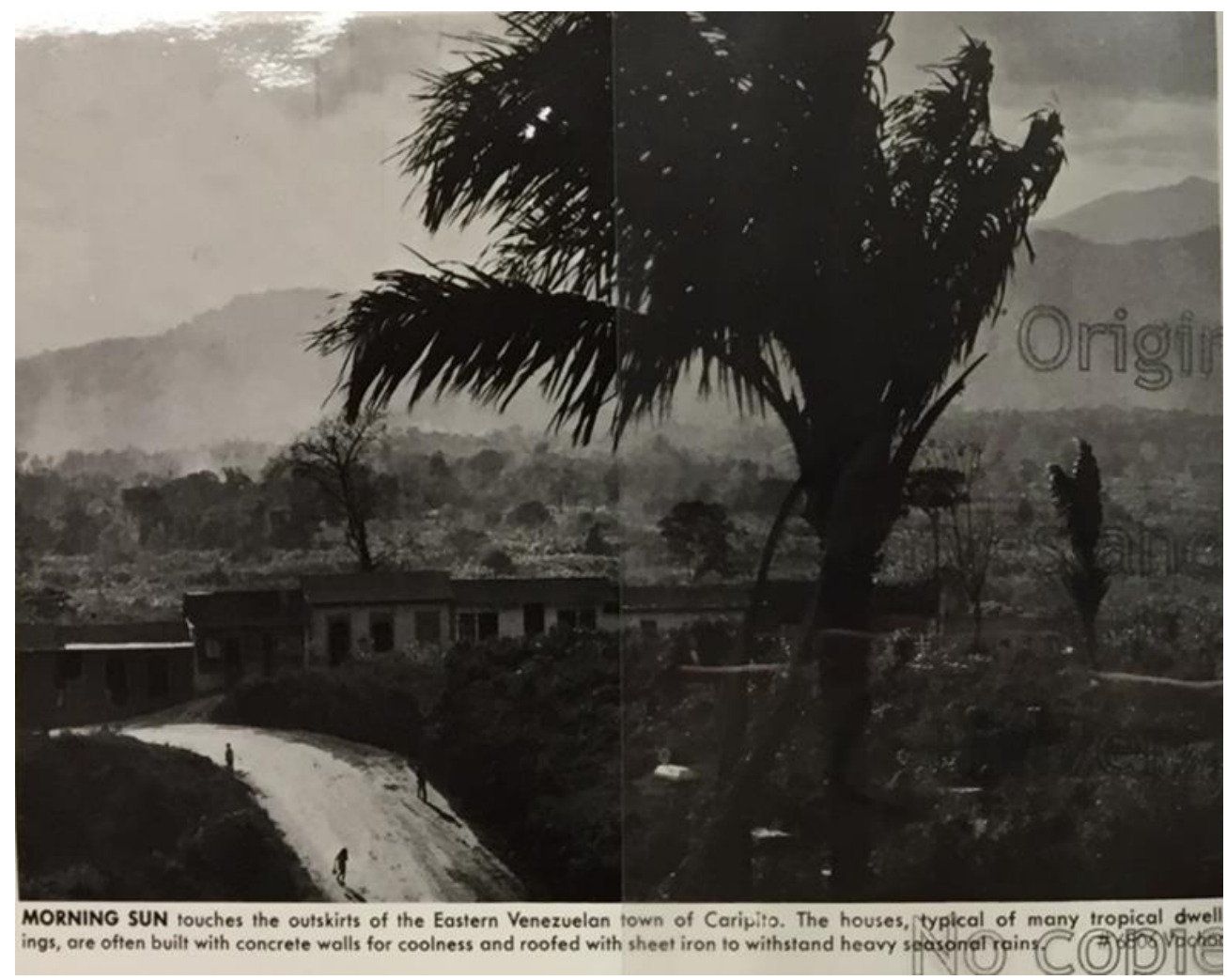

Image 24 - (Photo Memo No 1. October 1945, Schinas Collection. Special Collections, Ekstrom Library; University of Louisville, p 4) 
A brief context of oil production in Venezuela reveals other discrepancies between the simplistic and rather rosy SONJ representation and a more complicated relationship Venezuela had with its foreign oil companies. Oil had been known about in Venezuela for centuries. Oil concessions were sold to foreign oil companies as early as 1910 . By 1917 , the once agriculture based economy had started importing most of its food supply and built an economy almost completely dependent on exporting oil (Salas 2009; Lieuwen 1954). However, the SONJ Photo Memo No 1 portrayed a history that was only two decades long (since 1945) and called Venezuela 'one of the last remaining open frontiers'. This shortened and falsified timeline was helpful in the production a discourse of expansion and control that then helped justify 'frontier' exploration to the American public who would view these texts.

In the same memo, on page $11, \mathrm{SONJ}$ focused again on the training of a Venezuelan workforce and on the services SONJ is providing the country (1945). Three small portraits of Venezuelans were juxtaposed to a larger picture of an oil derrick emerging out of thick tropical vegetation. Two of the portraits were of oil workers and one was of a child who was in a classroom of a company built school (scans provided below).
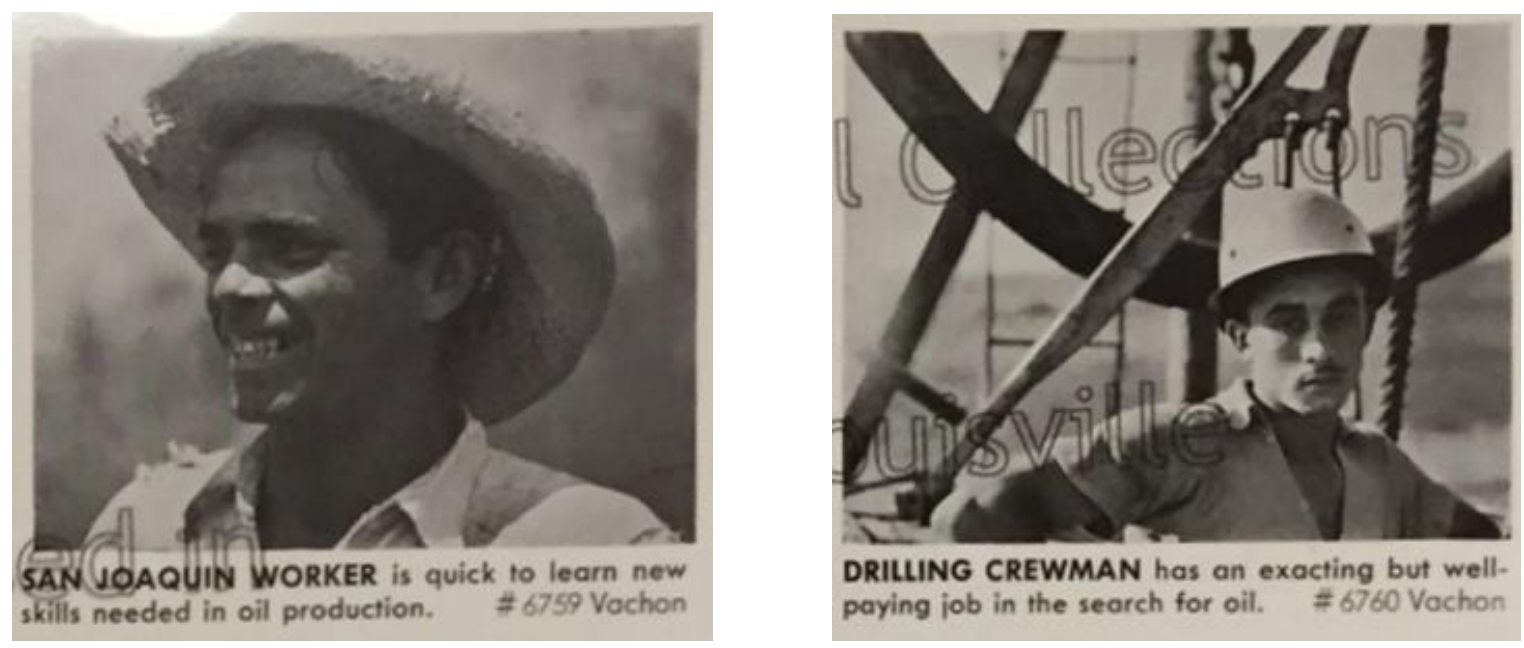


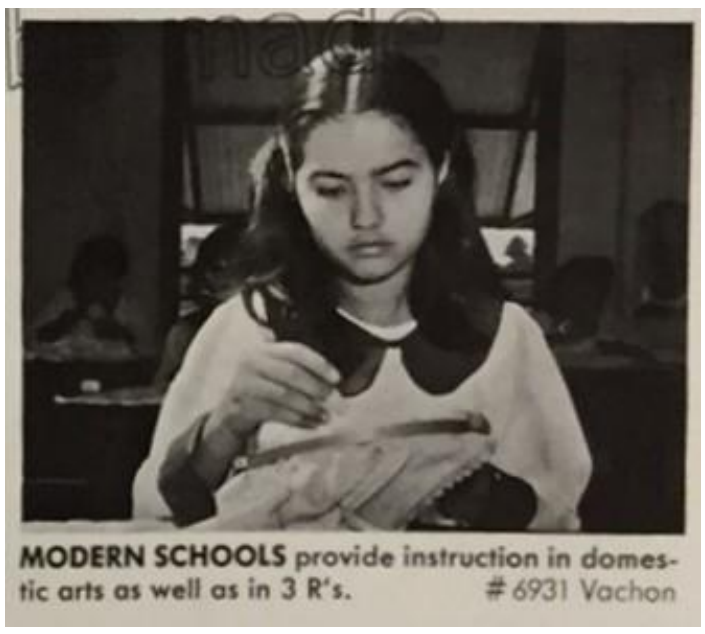

Captions:

Image 25 - San Joaquin Worker is quick to learn new skills needed in oil production.

Image 26 - Drilling Crewmen has an exacting but well-paying job in the search for oil.

Image 27 -Modern Schools provide instruction in domestic arts as well as in 3 R's.

(all three photos found in. Photo Memo No 1. 1945, October. Schinas Collection. Special Collections, Ekstrom Library, University of Louisville.)

The tone of the portraits' captions was undeniably patronizing. Roles of service provider / service beneficiary were established over employer / employee. And then those roles were racialized. The oil company was depicted as 'modern' and as 'experts' and the Venezuelan was depicted as grateful recipient. These roles echo that of colonizer and colonized, developed and undeveloped. The imperial characteristic of big oil companies has been noted elsewhere (Watts 2008; Salas 2009; Klare 2004; Yergin 1991). The degree at which this depiction flattened out and simplified the complex politics of oil and of labor in Venezuela is obscene. Photographer John Vachon noted as much in a correspondence letter to project manager Roy Stryker while in Venezuela in 1944 on his first assignment as SONJ employee. The letter was a general update on Vachon's travels- contacts he had made, stories he was working on and some of the difficulties he was having. It consisted of rather mundane particularities of the profession except one paragraph that references an assignment Stryker had given him to photograph Venezuelans in technically skilled or official positons. Vachon explained that this script was impossible to complete because of a divided work 
force along the lines of race. He then described the prevailing racist culture in the segregated work camps (below).

...I'll try to get some of the Venezuelan "officials" of the Co. you mentioned. The idea is not exactly applauded here. If I'd known that I could have shot some of the stooges while I was in the field, but I didn't. Believe me this is a crappy company. I would like to spend lots of time in Venezuela unhampered with association with an oil company. There is all over an attitude and a prejudice which is pawned off as what the "better class Venezuelans" want, but I have seen for sure that that is only a bolstering up process for the Texas point of view. After a couple months down here I had almost decided I didn't like Americans, when I met a sailor from Michigan in Puerto la Cruz. He was a great guy, and he reaffirmed me. There was a big disturbance one night in San Joaquin camp while I was traveling with a dark skinned guy from Caripito, one of the laboratory men. He stayed with me in the American camp, and 18 Texans fainted..... [sic]. (Vachon Correspondence April 15, 1944. Schinas Collection, Special Collections Eskrom Library, University of Louisville.

This is a moment where the tension between photographic documentation and corporate promotion is explained through the experience of one photographer. Clearly Vachon and Styker had developed a previous relationship based on more journalistic values that Vachon perceived to conflict with their new employer. Vachon even offerd to shoot "stooges" who were not engaged in the skilled positions who could be passed as "officials". Creole's racism was not a new revelation. Salas writes about the horrific treatment of Venezuelans by foreign oil companies comparing them to the United Fruit Company plantations in other parts of Latin America (2009). But what is important to note here is that the SONJ public relation department continued to construct a narrative of progressive industrialism that perpetuated a nationalistic discourse of expansion and control.

A social investment in Venezuela was not the only 'achievement' SONJ public relations promoted. The massive operation to construct hundreds of over-water wells in the Tia Juana field under Lake Maracaibo was described as an unmatched engineering marvel by 
not only SONJ publications but other unaffiliated petroleum textbooks (Fanning, 1947;

Sckackne and Drake, 1950). One photo taken of the lake by Vachon in February 1944 was one of the most circulated photos from the collection (Vachon, \#1056). It was used in technical and educational literature to show the advancements made by the oil industry in general, not just those of SONJ. This photo reads as unpalatable to a post 2010 Gulf spill sensory, but at the time it was celebrated. It became a favorite of the public relations department and they used it a variety of ways. In a filmstrip (Image 28) made to "encourage the use of photography in public relations" during a presentation given to the General Electric Company in November 1946, the lake photo is used five different times. Table 6 captions to filmstrip. The same frames used in the filmstrip were also used in a how-to manual that was given to visitors of the photo archive (Training Program. 1948. Stryker Papers, Special Collections, Ekstrom Library, University of Louisville.)

Slide 2: Photography is part of Jersey's public relations program because it is a means of communication that knows no language barriers.

Slide 3: This picture tells Venezuelans about oil in Venezuela

Slide 4: The same picture tells other people about oil in Venezuela

Slide 29: The message in a photograph is often strengthened by subsidiary pictures.

Slide 30: A picture supported by an opposite

Slide 31: A picture supported by a complement

Table 5. SONJ Photo File ‘Training Program': Film Strip Captions 

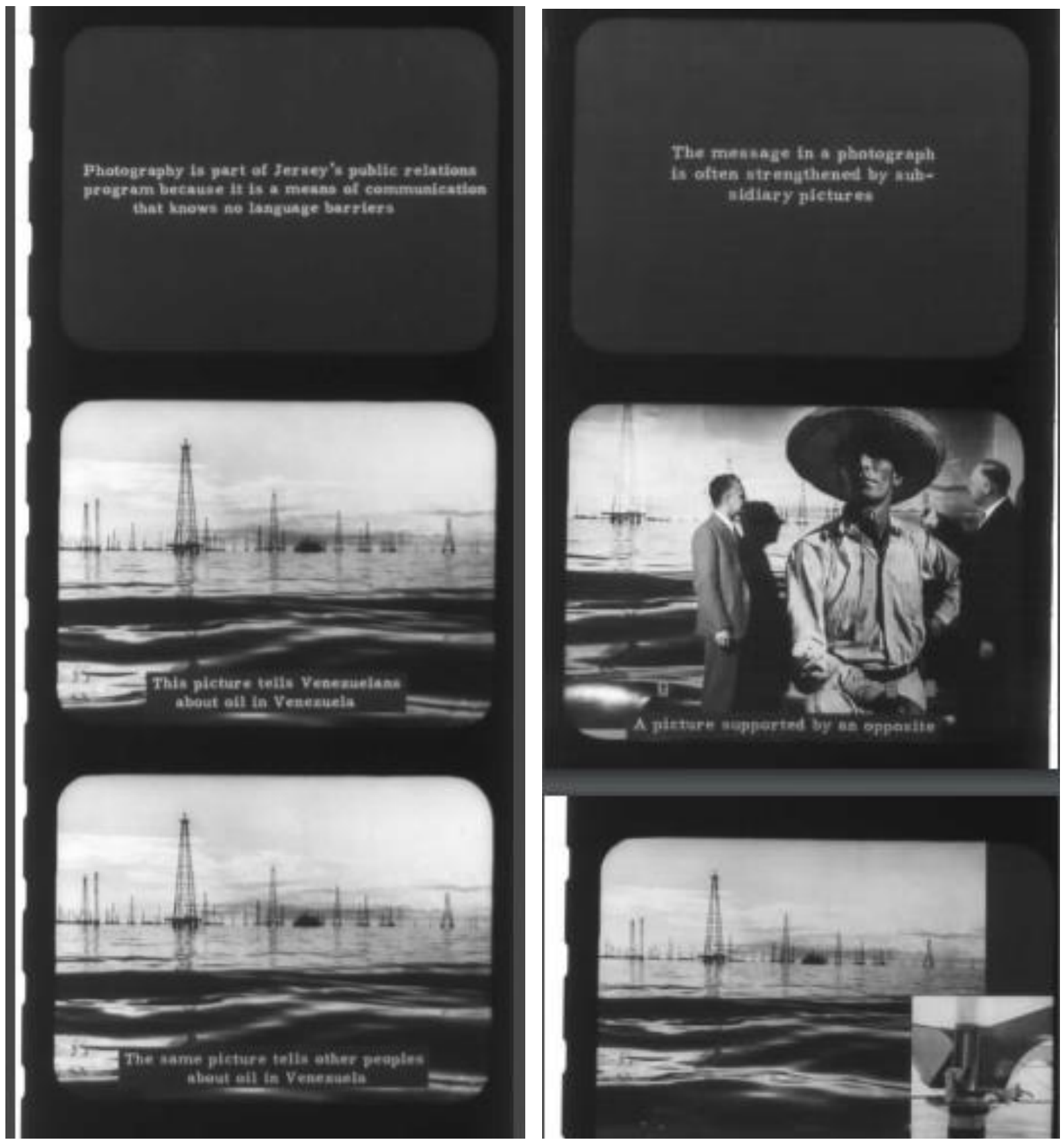

Image 28 Film Strip to "encourage the use of Photography in Public Relations" (film strip 002. 1946. Schinas Collection, Special Collections, Ekstrom Library, University of Louisville; slides 2-4 (left), slides 29-31 (right)) 
The intent of the presentation was to show how photos were flexible in their use and could be paired with text and other photos to strengthen a message or a desired effect. From a communications stand point, the lecture seems elementary. But from a methodological study, this filmstrip was a strategy for the same progressive industrialism the industry perpetuated as it promoted foreign expansion. SONJ reproduced the role of expert servicing the under developed. Oil was conceptualized as a neutral object of a particular 'modern' technological development. This narrative was diffused into the seemingly apolitical presentation on the benefits of photography. This was a casual misrepresentation of the oil industry in Venezuela and a fabricated spatial description of Lake Maracaibo.

Lake Maracaibo was not a remote area, nor was oil production on the lake hidden from sight. Lake Maracaibo is a massive body of water in western Venezuela that supplied the surrounding population with fresh drinking water. Community complaints of mismanagement were taken up by multiple unions as early as 1937 (Lieuwen 1966; 75). Pollution, the smell of leaked natural gas, a dying fish population and pipelines that were built above the surface of the water that prevented local boat traffic were some of grievances (1966). Put bluntly, Venezuelans did not need the picture to tell them about oil production on the lake (Table 6). The photo below (Image 29) showed how the water content of a new above-water well was checked by releasing the run off into the lake. This picture was not widely distributed by SONJ. 


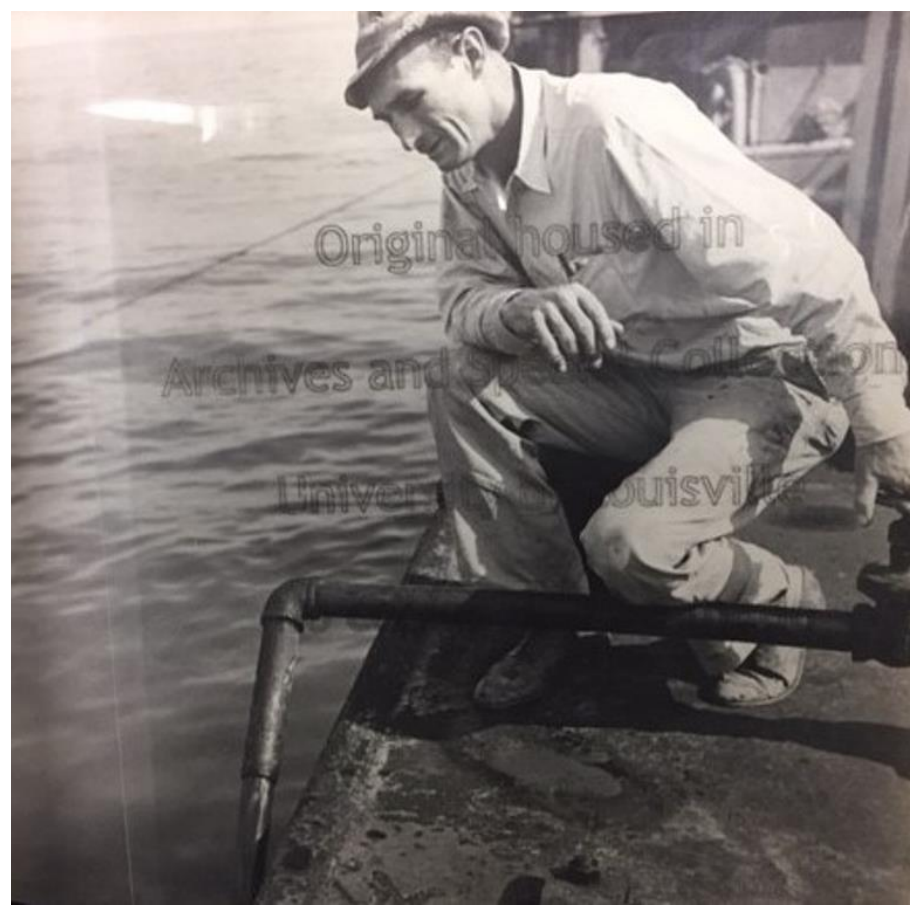

Image 29. (\# 1475 Vachon, 1944, February. Special Collections, Ekstrom Library, University of Louisville)

Original Vachon Caption:

Checking the water content of oil on well which has just come it on Lake Maracaibo [sic].

Salas (2005) and others (Lieuwen 1963; and Martz 1966) write about the widespread dislike for Creole (SONJ affiliate), Shell and Mene Grande (Gulf affiliate) - the three largest foreign oil companies in Venezuela. Lieuwen believes that Venezuela would have followed Mexico and Bolivia in nationalizing the oil companies if Venezuela had been able to diversify its economy to the extent it could withstand the difficult few years of transition after take over (1963). Venezuela did nationalize later in 1976. But in 1945, 25 percent of the population's employment was somehow connected to the foreign oil companies and over 54 percent of the government's budget came from oil taxes and royalties from oil export (1963). Political parties gained popularity when seen as having a tough stance toward the companies but once in office were limited in the demands they could make simply because the government was so dependent (Salas 2005). The Petroleum Law of 1943 was the nation's first petroleum reform legislation and addressed some of the country's long standing concerns. Included was the famous 50/50 profit sharing agreement that became a precedent 
globally as other oil producing counties negotiated oil concessions with the major multinational producers. The law also required that at least $90 \%$ of each segment of the oil workforce be native born Venezuelan. This was in response to a highly segregated industry where the majority of the higher paying skilled jobs were held by white Americans and Europeans. This also prevented the companies from hiring large amounts of immigrant labor from the West Indies and Mexico, as these immigrants were less likely to be members of labor unions (Liewen 1963; 74). The law also closed the sale of any new oil concessions. However, this in the end helped the big three companies because they were able to produce on their already existing contracts without having to compete with new producers who were trying to buy in (Lieuwen 1963). In October 1945, a new left regime called Acción Democrática (AD) was ushered to power by a military coup. The AD was, in rhetoric, more critical of foreign oil. They had strong ties to the oil labor unions, they recognized the Communist party and they vowed to strictly monitor the foreign companies' production levels. Salas has countered some of the prevailing histories of Venezuela by claiming that the AD's regain from 1945-1948 was not as exceptional and anti-imperial as they claimed (2005). He writes how particularly Standard Oil New Jersey adapted to political changes and sought to influence reforms that would affect their company's interests. The company negotiated concession contract changes rather than confront and oppose them. They signed a new labor contract with the Oil Workers Federation while SONJ famously had rarely ever acknowledged unions. They agreed to open company roads and work camp services to a wider population. And in 1946 they, along with Shell, agreed to build new refineries in the country even though in the past they had been hesitant to build new infrastructure because of a fear of nationalization. (Salas 2005). All this adaptation was done in cooperation with AD 
and in conjunction with the U.S. government. Here, the US foreign policy was formed directly by the interest of U.S. based oil companies to, 1) limit the rise of a militant independent labor movement, 2) eliminate communist influences, and 3) avoid oil nationalization (Salas 2005; 151). Venezuela was monitored closely by both industry and government. While publicly in America, Venezuela was held as a positive example of how an oil producing economy could develop with the help of the U.S. (Fortune 1949; TIME 1955), the CIA monitored communists in the labor movement, the US military was present during political demonstrations, and the Creole company constantly surveyed citizens in order to gage levels of dissent (Salas 2005). Creole's internal polling data from 1947 shows that 82 percent of university students and 72 percent of the country as a whole wanted to nationalize the oil industry $(2005 ; 5)$.

"Oil operations are, for all practical purposes, instruments of our foreign policy toward these (oil producing) countries" (US National Security Council 1953; 1322).

There was a larger theatre where SONJ's 'frontier' making and progressive industrialism narrative resounded. This period was a context where both U.S. government and corporate industry were constructing new approaches to the old problems of development and market stabilization all while being confronted with labor disputes, perceived threat of communism, and a trend toward nationalization worldwide (Randall 2005). The SONJ photograph collection's representation of oil production outside the US, and specifically in Venezuela, gives a window into the policy and practice of Standard Oil New Jersey's negotiation of new roles industry was expected to fulfill and the company's active participation in the reconceptualization of those roles. During WWII and the years following, a heightened discourse around national security brought into scrutiny the United States' oil supply and their established oil reserves (Labban 2008). This intensified the 
degree of government involvement in what was historically left to the private U.S. oil companies (Huber 2013; Randall 2005; Yergin 1991). Large oil companies such Standard Oil New Jersey had operated internationally since before the turn of the century and by WWII had hundreds of affiliate companies around the world involved in all segments of the industry - the production, transportation, and marketing of oil. But the postwar years are noted as a time of dramatic corporate and diplomatic expansion in the arena of oil (Randall 2005; Yergin 1991). In Venezuela for example, both SONJ and the U.S. state department were monitoring and adapting to foreign politics. However, what SONJ Photo Memo calls "frontier making" involved the politically neutral training of a foreign workforce and building a foreign infrastructure. These representations of oil abroad were enthusiastically promoted. What was left out was the political maneuvering and adaptation by both the U.S. government, SONJ and the creation of oil as a geopolitical object. Instead of viewing geopolitical relations as objective fact, a critical geography shows that certain geopolitical discourses get produced and reproduced to legitimate specific power relations (Bradshaw 2010). The production of oil was an active moment in the construction of specific geopolitical imaginaries. Its extraction was key to the production of narratives of nationalism and inclusion vis a vis intense cultural othering. It was often these narratives that justify local geographies of dispossession and destruction of the environment (Perreault 2013; Valdivia 2008). Further, oil was often seen as a magic bullet commodity, capable of ushering in wealth and development (Watts, 2008; Coronil 1997; Reed 2009), even though this vision was often proved false. Le Billon and Cervantes argue for oil to be viewed as more of a curse (2009). The result of this frontier making was directly linked to the issue of state power and territoriality - oil as a geopolitical object. Oil was the object of concern in 
state formation and in forms of conflict and/or cooperation between states. I argue that none of this complexity is given in the SONJ's distribution of their photo file.

Implication

The Photo Memos show the SONJ photograph collection was a physical manifestation of a complex set of discourses surrounding concepts of nationalism and resource management. While it may seem that my distinction between 'domestic' and 'foreign' suggests an exacting subjugation of the social relations under a simplified geopolitic and an uncritical accepting of national territory, my intent is different. My aim is to understand how the cultural discourses of oil are embedded in a social production of space, i.e. how an 'American way of life' is entangled in imaginaries of oil production beyond a domestic border. Further, this chapter has argued that, unique to this archive was the juxtapostioning of foreign production and domestic production, of conservation and abundance. This intertextuality produced a discourse of control and planning in the midst of expansion during the post WWII years. I do not believe that this was always an exact one-toone mapping of domestic production being conserved and controlled while foreign production was characterized as abundance. There is no evidence in the archive of this being explicitly stated. I do argue that the resulting geographic imaginary of oil was one where the usually blatant contradictions of conservation and abundance, of domestic and foreign, were normalized to the extent that they no longer seemed contradictory. 


\section{CHAPTER VI}

\section{CONCLUSION}

The case of Standard Oil New Jersey's Photograph Collection 1943-1951 was one of a fantastically large and beautifully executed project that attempted to document anything and everything about the oil industry. It was a case of scandal. It was a case of exploration and 'self education' by a well-funded group of consultants and photographers. By the end, the public relations department had spent over a million dollars in labor and prints (Plattner 1983; 4). This case also represents a corporation's response to crisis, expansion, and volatility fueled by tropes of restraint, accountability, and interdependence. This thesis has unpacked these dominant representations through a contextualized discourse analysis. This case is relevant because of Standard Oil New Jersey's massive influence upon oil history and due to the significance of the post WWII era upon both current oil production practices and on oil-use practices.

In terms of research related to the SONJ photo archive, this thesis provides a new interpretation of the genres found within the archive by making a distinction between the site of production and the site of distribution. Using methods delineated by Rose (2001), 
comparisons between these sites have illuminated discursive strategies that up to this point had not been researched.

This thesis shows how these discourses have produced the rural extraction sites of the 'oil town' and of 'oil country'. The result wa a geographic imaginary in which the oil industry emerged as unobtrusive and an equitable player engaging in small town America. The visual association of oil technologies like oil derricks and oil refineries alongside the familiar small town scenes like front porches, football practices and American flags has produced what I call the scopic regime of the Americana. This regime constructed how we view oil view to be synonymous with an American way of life.

The visual framing of oil was also a simplification of a politically controversial definition of conservation. In an engineered pairing of spaced out oil derricks and a written text that gave selective technical detail, the SONJ constructed subversive defense of big oil and of a controlled and regulated oil market. The photo memo text presented the company as accountable and efficient in the face of chaos and waste. In a similar simplification, the SONJ public relations promoted the practice of progressive industrialism and technological advancement in Venezuela. Through social investment in the Venezuela infrastructure and a Venezuela workforce, SONJ displayed how oil can assist in developing poorer, oil producing countries. This project has shown this narrative to be an obscene simplification of Venezuelan politics and a redacting of Creole Petroleum's exploitations of Venezuelan resources and labor. This account can add to the account of big oil as colonizer. Further, this project has engaged an uncommon pairing of conservation and abundance, at both the foreign and domestic scale, to show how the casual juxtapositioing of photographs normalized the seemingly contradictory subjects and constructed a banal, taken-for-granted partnership. 


\section{Contributions}

An important contribution to Geography, is a revitalization in the use of the archive as a site of analysis. This account of 'archival fieldwork' is unique to my thesis but can assist future study of similar cases. Following Harris (2001), I argue that the study of past places and of past socio-environmental relations is well within the discipline of Geography. The present day is not detached from the past. If ethnographic field work and landscape analysis can study the present, and archaeology can study the distant past, then the archive can illuminate our understanding of the in-between. I also believe that Geography can benefit from the continued development of visual methods. As Rose (2001) reminds us, society is increasingly dependent on the visual. This thesis provides an intertextual application for engaging both written and visual text.

Contributing to Geographies of Oil, this project proposes that the sources of the oil commodity cannot be separated from the place making projects at a variety of scales: everyday use by the petroleum consumer; small town Americana; and the geopolitical productions of oil states like Venezuela. The visual text is instrumental in this production of scale. This project shows that the photograph is a productive force in constructing the very objects that it purports to represent. Geographer Mathew Huber (2015) writes of the recent "boom" in the humanities and social sciences taking up energy as a research focus. Huber argues for a recommitment to a subfield of Energy Geography that would be able take in to account the spatialities of energy and also engage critical social theories that the humanities bring (2015). Such an approach treats energy as an ideological concept rather than simply an empirical resource. I echo this call for Energy Geography and believe that there are multiple research sites that could be analyzed in a similar vein as this thesis. This project has 
synthesized recent critical interdisciplinary work on discourse and oil and has purposed a way for Geography to take up this topic by use of Lefebvre's theory on the production of space (1991), however there could be other geographic methods to use. Lastly, I believe the role Geography can play in an energy system transition to be significant. Following Huber (2015), this transition cannot be purely reliant on policy. Any new system toward a lowcarbon or renewable energy must take into account the spatialities of our everyday practices and our culture of energy use. This will require new geographic imaginaries of energy.

\section{Limitations}

The SONJ photograph collection as an archive is vast and complex. Its size and richness would allow for further analysis. For example, I have chosen to write about the production of oil towns and the politics of conservation and Venezuela. However, I could have just as easily written about urbanization and pre-sprawl, or science and technology research with in the oil industry or Saudi Arabia. In fact, I did gather notes on these topics. Regretfully, I did not have the time nor space to include that material for this project. That said, the researcher is in a subjective position where choices are made based the limitations of human energy and attention.

Further, while researching this project, I have found that the oil industry has produced many media texts in its short history, including: technical literature, histories, films, and paintings that look more like classical art that would be in a museum. Therefore, a similar visual discourse method could be employed upon similar historic records. Perhaps a unique characteristic of the oil industry during this time is its investment in providing the public with massive amounts of dense information. That said, this project is limited to the single archive 
source. My historic record is dependent on what has been preserved by SONJ, by Roy

Stryker and by the supplemental archive by Michael Schinas who was a public relations employee and gave documents to U of L Special Collections. The preservation of the archive is a social and political process and it is most defiantly not complete (Hanlon, 2001). For a more detailed examination of, for example oil towns, I could piece together multiple archival material for a more "complete" historic record. However, this would be a problem-oriented research project rather than a source-oriented.

\section{Epilogue}

The following is an epilogue for my thesis. Its goal to establish significance by showing how SONJ public relations practices and the use of photography spread throughout the oil industry and the larger corporate culture after my period of study.

By 1948, Roy Stryker and the public relations department in New York had built up a substantial photo file and was efficiently filling print requests from all over the world. Many of these requests were from affiliate companies who either wanted an interchanging gallery rotation of exhibitions for their offices, like the West Virginia Standard Oil Sales Division, or wanted a stock photo file for themselves so they could create their own literature and satisfy local publication needs (West Virginia Sales Division, 1948). Requests to curate location specific sets of prints, like Carter Oil's request for an exhibition highlighting their producing territory (1948), were time consuming and sometimes impossible if a photographer had not been assigned to travel in an affiliate's operational territory. The PR department began sending what they called a "Nucleus Set of Photographs" to affiliate companies: 100 prints at $8 \frac{1}{2}$ "x 11 " with a "fine grain copy negative of each print" (Østlandske Petroleumscompani 
letter, 1948). "These (100 prints) were carefully selected from the Jersey photographic library for the purpose of providing affiliates with a nucleus photographic file covering the different phases of operation" (1948). The companies were encouraged to replicate SONJ processes and begin to add to the photo file. Tables 7 and 8 are lists of Latin American and European affiliates that were sent a nucleus set. The issue of company identity is addressed in the letter sent to the affiliates, "In distributing the photographs outside your company you should insist the credit be given to your local organization. Several affiliates have preferred the words, 'Esso Photo', as an appropriate credit” (1948). Other affiliates had reported that they did want their association with "Standard Oil" to be known (Larson, Knowlton, and Poople 1971; 657). Regardless of the reason, the liberal citation policy of the SONJ public relations at the time makes it difficult to track just how far the photos circulated.

\begin{tabular}{|l|l|}
\hline Company & Location \\
\hline H.A. Matzger (SO of Argentina) & Buenos Aires, Argentina \\
\hline Standard Oil Company of Brazil & Rio de Janeiro, Brazil \\
\hline Esso Standard Oil (Antilles) S.A. & Port of Spain, Trinidad \\
\hline Esso Standard Oil (Caribbean) S.A. & Cuidad Trujillo, Dominican Republic \\
\hline Esso Standard Oil (Central America) S.A. & Panama, Republic of Panama \\
\hline Standard Oil Company Chile, S.A.C. & Santiago, Chile \\
\hline Tropical Oil Company & Bogota, Colombia \\
\hline Standard Oil of Cuba & Havana, Cuba \\
\hline International Petroleum Co., Ltd. & Lima, Peru \\
\hline Esso Standard oil Co. (Puerto Rico) & San Juan 3, Puerto Rico \\
\hline Standard Oil Co., S.A. Uraguaya & Montevideo, Uruguay \\
\hline Creole Petroleum Corporation & Caracas, Venezuela \\
\hline
\end{tabular}

Table 6. Latin American Affiliate Companies sent nucleus photo set. (Source: Public Relations: Nucleus Set of Photographs, 5 July, 1948. Stryker Papers. Special Collections, Ekstrom Library, University of Louisville: Louisville, KY.) 


\begin{tabular}{|l|l|}
\hline Company & Location \\
\hline Standard American Petroleum Company, S.A. & Antwerp, Belgium \\
\hline Det Danske Petroleums Aktieselskab & Copenhagan, Denmark \\
\hline Anglo American Oil Company, Ltd. & Westminter, London, England \\
\hline Standard Française des Pétroles & Paris, France \\
\hline Management Committee Esso Haua & Hamburg, Germany \\
\hline Osakeyhtiö Nobel Standard Aktiebolag & Helsingfors, Finland \\
\hline Standard Italo-Americana Petroli & Genoa, Italy \\
\hline Standard Amerikanische Petroleum Company & The Hague, Netherlands \\
\hline Ostlandske Petroleumcompagni & Olso, Norway \\
\hline Svenska Petroleum AB Standard & Stockholm, Sweden \\
\hline Standard Mineraloel Produkte & Zurich, Switzerland \\
\hline
\end{tabular}

Table 7. European Affiliate Companies sent nucleus photo set. (Source: Public Relations: Nucleus Set of Photographs, 5 July, 1948. Stryker Papers. Special Collections, Ekstrom Library, University of Louisville: Louisville, KY)

Establishing an Industry Practice

The creation of visual material caught on as an established practice and paralleled the formation of public relation departments across the oil industry. Letters between members of the SONJ public relations department on multiple occasions brought up Shell's efforts to start a photographic file (Stryker Papers, 1948). The SONJ public relations department believes its file to be better however they do think that Shell made nicer educational panels. I have already mentioned that the practice extended outside of the oil industry to General Electric (Exhibitions list, 1947). In 1953, Sun Oil creates an exhibit, at the Franklin Institute called "Oil Serves America” which explained the sources of oil, modern extraction technologies, and then celebrated Sun Oil's innovations in refining. Its concentration was on North America. Barrett has discussed this exhibit as a reinvigorated defense of domestic production as Sun's competitors began to concentrate on foreign production. $(2012 ; 421)$. SONJ had been there at the Franklin Institute with their own exhibition twice before, their 
first one in 1945 and another in 1948. Sun used some of the same methods SONJ had used mixing photography with technical text, educational panels with graphics. These exhibitions got a press release and a write up in Franklin Institute's own newsletter. These formats must have answered the symbolic needs for each company. It just so happened that by 1952 , SONJ was one of the foreign producing competitors that Sun was trying to pit itself against. 


\section{REFERENCES}

Anderson, J. C. ed. 1977. Roy Stryker: The Humane Propagandist. Louisville, KY. University of Louisville.

Bailey, A., C. Brace, and D. Harvey. 2009. Three geographers in an archive: positions, predilections and passing comment on transient lives Transactions of the Institute of British Geographers 34: 254-69.

Baker, A. R. H. 1997. 'The dead don't answer questionnaires': researching and writing historical geography. Geography in Higher Education. 21: 231-243.

Barrett, R. 2012. Picturing a Crude Past: Primitivism, Public Art, and Corporate Oil Promotion in the United States. Journal of American Studies. 46 (2): 395-422.

Barrett, R. and D. Wordon 2012. Special Issue 02 Oil Culture: Guest Editors' Introduction. Journal of American Studies. 46 (02).

Biemann, U. and A. Pendakis. 2012. This is Not a Pipeline: Thoughts on the PoliticoAesthetics of Oil. Imaginations. 3 (2): 6-16.

Black, B. 2000. Petrolia: The Landscape of America's First Oil Boom. Baltimore, Md.: John Hopkins University Press.

Bradshaw, M. J. 2010. A new energy age in pacific Russia: lessons from the Sakhalin oil and gas projects. Eurasian Geography and Economics 51 (3): 330-359.

Bridge, G. and Le Billon, P. 2013. Oil. London: Polity.

Buell, F. 2012. A Short History of Oil Cultures: Or, the Marriage of Catastrophe and Exuberance. Journal of American Studies. 46 (2): 273-293.

Cable, S. 2012. Sustainable Failures: Environmental Policy and Democracy in a PetroDependent World. Philadelphia, PA: Temple University Press.

Cook. 1941. Control of the Petroleum Industry by Major Oil Companies. Temporary National Economic Committee Monograph No. 39. Washington DC.

Coronil, F. 1997. The magical state: nature, money and modernity in Venezuela. Chicago: University of Chicago Press.

Crang, M. 2010. The Death of Great Ships: Photography. Politics and Waste in the Global Imaginary. Environment and Planning A: 42 (5): 1084-1102. 
Energy Information Administration. 2016. World Oil Outlook. http://www.eia.gov/beta/international/rankings/\#?prodact=5-2\&cy=2013 (last accessed, September 7, 2016).

Foucault, M. 1972. The Archelogy of Knowledge. Translated by A.M. Sheridan Smith. London. Tavistock Publications.

. 1977. Discipline and Punish: The Birth of the Prison. Translated by A. Sheridan. London. Allen Lane.

Fortune. It's hot in Venezuela. May 1949: 15

Frohardt-Lane, S. 2012. Promoting a Culture of Driving: Rationing, Car Sharing, and Propaganda in World War II. Journal of American Studies. 46 (2): 337-355.

Gismondi, M. and Davidson. D.J. 2012. Imagining the Tar Sands 1880-1967 and Beyond. Imaginations. Vol 3 (2): 68-103.

Hanlon, J. 2001. Spaces of interpretation: archival research and the cultural landscape. Historical Geography. 29: 14-25.

Harris, C. 2001. Archival Fieldwork. The Geographical Review. 91 (2): 328-334.

Harvey, D. 1989. The urban experience. Baltimore, MD: Johns Hopkins University Press. . 1974. Population, resources, and the ideology of science. Economic Geography. 50 (3): 256-77.

Huber, M. 2015. Theorizing Energy Geographies. Geography Compass. 10: 1-12.

- 2013. Lifeblood: Oil, Freedom, and the Forces of Capital. Minneapolis: University of Minnesota Press.

- 2012. Refined Politics: Petroleum Products, Neoliberalism, and the Ecology of Entrepreneurial Life. Journal of American Studies. 46 (2): 295-312.

- 2011. Enforcing Scarcity: Oil, Violence, and the Making of the Market. Annals of the Association of American Geographers. 101 (4): 816-826.

- 2009. "The Use of Gasoline: Value, Oil, and the American way of life". Antipode. 41 (3): 465-486.

- 2008. Energizing historical materialism: Fossil fuels, space and the capitalist mode of production. Geoforum. 40: 105-115. 
Kashi, E. and M. Watts. 2010. The Curse of Black Gold: 50 Years of Oil in the Niger Delta.New York: Powerhouse Books.

Keller, U. 1986. The Highway as Habitat: A Roy Stryker Documentation, 1943-1955. Santa Barbara Art Museum.

Kemnitzer. 1938. Rebirth of Monopoly, A Critical Analysis of Economic Conduct in the Petroleum Industry in the United States. Harper and Bros. New York.

Klare, M. 2004. Blood and Oil: The Dangers and Consequences of America's Growing Dependency in Imported Petroleum. New York: Metropolitan Books.

- 2001. Resource Wars: The New Landscape of Global Conflict. New York: Henry Holt.

Kurtz, M. 2001. Situating practices: the archive and the filing cabinet. Historical Geography. 29: 26-37.

Larson, H. M., E. H. Knowlton, and C. S. Poople.1971. New Horizons: History of Standard Oil (New Jersey) 1927-1950. New York: Harper \& Row, Publishers.

Labban, M. 2008. Space, Oil, and Capital. London: Routledge.

Le Billon, P., and A. Cervantes. 2009. Oil prices, scarcity and the geography of war. Annals of the Association of American Geographers. 99 (5): 836-844.

Le Menager, S. 2012. Fossil, Fuel: Manifesto for the Post-oil Museum. Journal of American Studies. 46 (02): 375-394.

Lefebvre, H. 1991. The Social Production of Space. Oxford: Blackwell.

Lemann, N. 1983. Out of the Forties. Austin, TX: Texas Monthly Press.

Lieuwen, E. 1965. Venezuela. London: Oxford University Press.

Lorimer, H. 2009. Caught in the nick of time: archives and fieldwork. in Aiken S., Crang, M., DeLyser, D., Herbert, S. and McDowell, L. eds. The Sage handbook of qualitative research in human geography. Sage, London: 248-272.

Martz, J. D. 1966. Acción Democrática: Evolution of a Modern Political Party in Venezuela. Princeton, N.J.: Princeton University Press.

Mitchell, T. 2011. Carbon Democracy: Political Power in the Age of Oil. London: Verso.

Musiol, H. 2012. Sundown and "Liquid Modernity" in Pawhuska, Oklahoma. Journal of American Studies. 46 (02): 357-373. 
National Research Council. 2002. Climate Change Science: Some analyses of key questions. Washington, D.C.: National Academy of Sciences.

Olien, R. M. and D. D. Hinton. 1982. Oil Booms: Social Change in Five Texas Towns. Lincoln: University of Nebraska Press.

Patchett, M. 2012. Reframing the Canadian Oil Sands: Curatorial Essay. Imaginations. 3 (2):140-169.

Pendakis, A and S. Wilson. 2012. Sight, Site, Cite: Oil in the Field of Vision. Imaginations. 3 (2): 4-5.

Peluso, N. L. and M. Watts. 2001. Violent environments. In Violent Environments, ed. N Peluso and M. Watts, 3-38. Ithaca, NY: Cornell University Press.

Perreault, T. 2013. Nature and nation: hydrocarbon, governance, and territorial logics of 'resource nationalism'. In Bebbington, A. and Bury, J. (eds.) Subterranean struggles; new dynamic of mining, oil, and gas in Latin America. Austin, TX: University of Texas: 67-90.

Plattner, S. W. 1983. Roy Stryker: U.S.A., 1943-1950: The Standard Oil (New Jersey) Photography Project. Austin. University of Texas Press.

Randall, S.J. 2005. United States Foreign Oil Policy Since World War I: For Profits and Security. Montreal: McGill-Queen's University Press.

Reed, K. 2009. Crude Existence: environment and the politics of oil in Northern Angola. Berkley, CA: University of California Press.

Rose, G. 2003. Family Photos and Domestic Spaces: A Case Study. The Institute of British Geographers. 28: 5-18.

—. 2001. Visual Methodologies. London. Sage Publication Ltd.

-2000. Practicing photography: an archive, a study, some photographs and a researcher. Journal of Historical Geography. 26.

- 1997. Situating knowledges: positionality, reflexivities, and other tactics. Progress in Human Geography. 21: 305-20.

Rostow. 1948. A National Policy for the Oil Industry. New Haven: Yale University Press

Sabin, P. 2005. Crude politics: The California oil market, 1900-1940. Berkeley: University of California Press. 
Salas, M. T., 2009. The Enduring Legacy: Oil, Culture, and Society in Venezuela. Durham and London: Duke university Press.

- 2005. Staying the Course: United States Oil Companies in Venezuela 1945-1958. Latin American Perspective. 32 (2): 147-170.

Schackne, S. and N.D. Drake. 1950. Oil for the World. New Yok: Harper \& Brothers Publishers.

Sekula, A. 1986. Reading an archive: photography between labour and capital. in P. Holland, J. Spence and S. Watney (eds). Photography/Politics: 2. London. Comedia. 153-61.

Sekula, A. 1989. The body and the archive. in R. Bolton (ed.). The Contest of Meaning: Critical Histories of Photography. London. MIT Press. 342-88.

Stocking and Watkins, 1951. Monopoly and Free Enterprise. The Twentieth Century Fund. New York. 389-392.

Szeman, I. 2012. Crude Aesthetics: The Politics of Oil Documentaries. Journal of American Studies. 46 (2): 423-439.

TIME Magazine. Venezuela. Creole: Good Neighbor. 19 December, 1955.

U.S. Departments of State, Defense and the Interior. 1953, January, 6. Report to the National Security Council on Security and International Issues Arising From the Current Situation in Petroleum. https://history.state.gov/historicaldocuments/frus195254v01p2/d159 (last accessed 24 April, 2017).

Valdivia, G. 2008. Governing relations between people and things: citizenship, territory and the political economy of petroleum in Ecuador. Political Geography. 27(4): 456-477.

Watkins. 1937. Oil: Stabilization or Conservation? A Case Study in the Organization of Industrial Control. Harper and Bros. New York.

Watts, M. 2008. Curse of Black Gold: 50 years of oil in the Niger Delta. New York: Powerhouse.

Withers, C.W. J., 2002. Constructing 'the geographical archive'. Area. 34(3): 303-311.

Worden, D. 2012. Fossil-Fuel Futurity: Oil in "Giant". Journal of American Studies. 46 (02): 441-460.

Yergin, D. 1991. The Prize: The Epic Quest for Oil, Money, \& Power. New York: Free Press. 
Zimmerman, E.W. 1957. Conservation in the Production of Petroleum: A Study in Industrial Control, Petroleum Monograph Series Volume 2. New Haven. Yale University Press.

Zuck, R. R., 2012. The Wizard of Oil: Abraham James, the Harmonial Wells, and the Psychometric History of the Oil Industry. Journal of American Studies. 46. (2): 313336. 


\section{APPENDIX A}

Archival Documents

The Standard Oil New Jersey Photographic Archive. Special Collections, Ekstrom Library, University of Louisville: Louisville, KY.

Bubley, E. 1945. Tomball captions. \#29908, \#26608

Corsini, H 1946. Cushing caption. \#37549.

Corsini, H. 1946. photo \#33311

Corsini, H. 1946. photo \#31796.

Corsini, H. 1946. photo \#37822.

Rosskam, E. 1944. photo and caption. \#12180

Vachon, J. 1944. caption. \#6808.

Vachon, J. 1944. (referenced in other text). \#1056

Stryker Papers. Special Collections, Ekstrom Library, University of Louisville: Louisville, KY.

Carter Oil. 1947, February. Exhibition request letter to Freyermuth.

Corsini, H. 1946, February 26. Letter to Stryker on Oklahoma story update. Correspondence.

Corsini, H. 1946, April 7. Letter to Stryker on Oklahoma an Cushing. Corisni Correspondence.

Franklin Institute. 1944. "Men of Oil” press release. Exhibits folder.

Freyermuth, Stanley, and Stryker letter. 1944. The Work of the Photographic Department As It Appears After Six Months Experience

Freyermuth, G. 1946, April. Freyermuth writes to Professor Moriam. Exhibits folder. Newson. 1942. Outline to SONJ board for new Public Relations Department. 
Newson, E. 1946, June 7. responds to a letter by Edward Stanley on corporate culture. Correspondence folder.

Østlandske Petroleumscompani. 1948. Letter to request photos.

Rosskam. 1945 April 14. Letter on Styker. Correspondence folder

Stanley, E. 1946. Letter to members to PR department on corporate culture. correspondence folder

Stryker. 1944, April 9. Stryker letter to Vachon in Venezuela. Correspondence folder

SONJ PR dept. 1948, August 15. Nucleus Set of Photograph to Østlandske Petroleumscompani

SONJ PR department. 1948. Training Program for the Photo file.

Vachon. 1944, March 29. Eastern Venezuela letter to Stryker. Correspondence folder West Virginia Sales Division, 1948. Letter to exchange exhibit galleries.

Michael Schinas Collection. Special Collections, Ekstrom Library, University of Louisville: Louisville, KY.

Coronet Magazine, 1946. Oiltown U.S.A.. Esquire Publications. pp 12-30.

film strip 002. 1946. Encourage the Use of Photography in Public Relations

Photo Memo No 1. 1945, October.

Photo Memo No 2. 1946, June.

Photo Memo No 4. 1947, August.

Photo Memo No 5. 1948, January.

Vachon. 1944, April 15. Letter to Stryker from Venezuela. Vachon Correspondence. 


\section{APPENDIX B}

Exhibition List Compiled (Source: Stryker Papers. Special Collections, Ekstrom Library, University of Louisville: Louisville, KY.

\begin{tabular}{|c|c|c|}
\hline Date & Location & $\begin{array}{l}\text { Title (general selection unless } \\
\text { named) }\end{array}$ \\
\hline Sep-44 & The Franklin Institute- Philadelphia, PA & $\begin{array}{l}\text { "Men of Oil: Roy Stryker } \\
\text { Collection" }\end{array}$ \\
\hline May-45 & $\begin{array}{l}\text { New York Public Library, } 135^{\text {th }} \text { Street } \\
\text { Branch - NY }\end{array}$ & $\begin{array}{l}\text { Industrial Photographs - by } \\
\text { Gordon Parks }\end{array}$ \\
\hline Jun-46 & Baton Rogue, LA & "Refinery at War" by Rosskams \\
\hline Apr-46 & Harvard Architectural School & The Architecture of Oil \\
\hline Apr-46 & Downtown Cmmercial School & Transportation \\
\hline Apr-46 & $\begin{array}{l}\text { International Nickel Co.: National Marine } \\
\text { Show }\end{array}$ & \\
\hline Apr-46 & Institute for American Democracy & \\
\hline Jun-46 & $\begin{array}{l}\text { American Institute of Chemists: Hotel } \\
\text { Biltmore }\end{array}$ & \\
\hline Jun-46 & SONJ Annual Meeting, Flemington, NJ & \\
\hline Jul-46 & National Chemical Society, Chicago & Grease Production \\
\hline Aug-46 & State Dept. OIC foreign centers & \\
\hline Sep-46 & Esso Training Center & \\
\hline Oct-46 & Agriculture Dept. California & \\
\hline Oct-46 & Baltimore restaurant photomural & Baltimore Refinery \\
\hline Oct-46 & $\begin{array}{l}\text { Campus Martine (The River Museum), } \\
\text { Marietta, Ohio }\end{array}$ & Rosskam's River Story \\
\hline Oct-46 & Council for Inter-American Cooperation & Oil in Venezuela \\
\hline Nov-46 & Museum of Modern Art & Textures \\
\hline Nov-46 & Dr. Frolich's Trip & \\
\hline Nov-46 & Hanover College & Geology \\
\hline Nov-46 & University of Michigan & \\
\hline Nov-46 & General Electric Company & to encourage photography \\
\hline Nov-46 & State Bureau of Adult Education & \\
\hline Dec-46 & McGill University, Montreal & \\
\hline Dec-46 & Sovfoto Agency & $\begin{array}{l}\text { examples of photography for } \\
\text { Russia }\end{array}$ \\
\hline Jan-47 & Massachuetts Institue of Technology & Employee Relations \\
\hline Feb-47 & State Department - Czechoslovakia & American Workers \\
\hline Mar-47 & Louisiana State University & \\
\hline Mar-47 & Mr. Russell's Trip & \\
\hline
\end{tabular}




\begin{tabular}{|l|l|l|}
\hline Mar-47 & State Department - Prague & Americana \\
\hline Apr-47 & Montana State College & \\
\hline Apr-47 & Holyoka, MA - Public Library & \\
\hline Apr-47 & Abe Cohen's Camera Exchange & Industrial nurses \\
\hline Apr-47 & $\begin{array}{l}\text { International Conv. of Nurses - American } \\
\text { Cancer Society }\end{array}$ & Vocational guidance \\
\hline Apr-47 & Career Counciling Service & Farming \\
\hline Apr-47 & Farm Editors Meeting & \\
\hline Apr-47 & Atlas Skymerchant, South American Flight & \\
\hline May-47 & Oklahoma A\&M & \\
\hline May-47 & University of Missouri & \\
\hline May-47 & Ohio State University & \\
\hline May-47 & University of Chicago & \\
\hline May-47 & Grove City College & \\
\hline May-47 & Investors' League, New Yorker Hotel & \\
\hline May-47 & US Camera Photo Carnival & Oil Today \\
\hline Jun-47 & Franklin Institute, Philadelphia & \\
\hline Jun-47 & US Information Center - Berlin, Germany & \\
\hline Jun-47 & War Department Photo Control Unit & \\
\hline
\end{tabular}




\section{CURRICULUM VITA}

NAME: $\quad$ Michael Poindexter

ADDRESS: $\quad 415 \mathrm{~W}$ Tenny Ave

Louisville, KY 40214

DOB: $\quad$ Lexington, KY; September 8, 1986

EDUCATION \& TRAINING:

B.A., Sociology

University of Louisville

2006-2010 